NBER WORKING PAPER SERIES

\title{
THE INTELLECTUAL SPOILS OF WAR? DEFENSE R\&D, PRODUCTIVITY AND INTERNATIONAL SPILLOVERS
}

\author{
Enrico Moretti \\ Claudia Steinwender \\ John Van Reenen \\ Working Paper 26483 \\ http://www.nber.org/papers/w26483 \\ NATIONAL BUREAU OF ECONOMIC RESEARCH \\ 1050 Massachusetts Avenue \\ Cambridge, MA 02138
}

November 2019, Revised January 2021

\begin{abstract}
We thank the Economic and Social Research Council for their financial support through the Centre for Economic Performance. Patrick Warren has provided truly outstanding research assistance. Pierre Azoulay, Josh Lerner, Heidi Williams, and participants in many seminars have given helpful comments. Mirko Draca kindly made his data on US defense procurements available to us, which was invaluable. We are also grateful to Sharon Belenzon and David Thesmar for useful discussions and sharing their data with us. The views expressed herein are those of the authors and do not necessarily reflect the views of the National Bureau of Economic Research.
\end{abstract}

NBER working papers are circulated for discussion and comment purposes. They have not been peer-reviewed or been subject to the review by the NBER Board of Directors that accompanies official NBER publications.

(C) 2019 by Enrico Moretti, Claudia Steinwender, and John Van Reenen. All rights reserved. Short sections of text, not to exceed two paragraphs, may be quoted without explicit permission provided that full credit, including $(\odot)$ notice, is given to the source. 
The Intellectual Spoils of War? Defense R\&D, Productivity and International Spillovers

Enrico Moretti, Claudia Steinwender, and John Van Reenen

NBER Working Paper No. 26483

November 2019, Revised January 2021

JEL No. O3,O30,O31,O33,O38

\title{
ABSTRACT
}

We examine the impact of government funding for R\&D - and defense-related R\&D in particular - on privately conducted $R \& D$, and its ultimate effect on productivity growth. We estimate longitudinal models that relate privately funded R\&D to lagged government-funded R\&D using industry-country level data from OECD countries and firm level data from France. To deal with the potentially endogenous allocation of government $R \& D$ funds we use changes in predicted defense $R \& D$ as an instrumental variable. In many OECD countries, expenditures for defenserelated $R \& D$ represents by far the most important form of public subsidies for innovation. In both datasets, we uncover evidence of "crowding in" rather than "crowding out," as increases in government-funded R\&D for an industry or a firm result in significant increases in private sector R\&D in that industry or firm. On average, a $10 \%$ increase in government-financed R\&D generates a $5 \%$ to $6 \%$ additional increase in privately funded R\&D. We also find evidence of international spillovers, as increases in government-funded R\&D in a particular industry and country raise private $R \& D$ in the same industry in other countries. Finally, we find that increases in private $R \& D$ induced by increases in defense $R \& D$ result in productivity gains.

\author{
Enrico Moretti \\ University of California, Berkeley \\ Department of Economics \\ 549 Evans Hall \\ Berkeley, CA 94720-3880 \\ and CEPR \\ and also NBER \\ moretti@econ.berkeley.edu \\ Claudia Steinwender \\ MIT Sloan School of Management \\ 100 Main Street, E62-521 \\ Cambridge, MA 02142 \\ and NBER \\ csteinwe@mit.edu
}

John Van Reenen

Department of Economics

London School of Economics

Houghton Street

London, WC2A 2AE

United Kingdom

and NBER

j.vanreenen@1se.ac.uk 


\section{Introduction}

Given the central role that productivity plays in explaining economic growth, it is not surprising that the search for the determinants of productivity has been central to modern economics. While a large body of empirical research has argued that R\&D is a key source of firm productivity growth (e.g. Aghion and Howitt, 1992; Romer, 1990), the question of exactly which policies governments should adopt to foster R\&D investment is still largely an open question.

In this paper, we study the impact of government funding for R\&D on privately conducted and financed R\&D, and its ultimate effect on firm productivity growth. We use two complementary longitudinal datasets - a country-industry-year-level dataset for OECD countries and a firm-year-level dataset for France - to address two related questions. First, we estimate the effect of government-funded $R \& D$ on private $R \& D$ - namely, R\&D conducted and financed by private businesses. We are interested in whether government-funded R\&D in a given country and industry (or to a given firm) displaces or fosters private R\&D in the same country and industry (or firm). Having found evidence of a positive effect (i.e. "crowd in" rather than "crowd out"), we next estimate how investment in R\&D affects productivity. For both types of analysis, we assess whether the benefits of public R\&D investment are limited to a single country or spill over across multiple countries. ${ }^{1}$

To isolate the causal effect of government-funded R\&D, we use quasi-exogenous variation in defense-related R\&D. Defense-related R\&D is an important but relatively understudied component of public policy on R\&D. It represents a key channel through which governments all over the world seek to shape innovation. In the US, annual government defense-related R\&D expenditures amounted to about \$78.1 billion in 2016, 57.2\% of all government-funded R\&D (Congressional Research Service, 2018). While defense-related R\&D is motivated by goals that are not mainly economic, it is often the most

\footnotetext{
${ }^{1}$ For a recent survey of the literature on the evaluation of innovation policies, see Bloom, Van Reenen, and Williams (2019). The literature focuses on two types of R\&D policies. First, there are fiscal policies towards R\&D such as Hall (1993), Bloom, Griffith, and Van Reenen (2002), Moretti and Wilson (2014), Dechezlepretre et al. (2019) and Rao (2016). This generally finds positive effects. Second, there is a body of empirical research on the effect of public R\&D on private R\&D (e.g. David, Hall, and Toole, 2000; Lach, 2002; Goolsbee, 1998; Wallsten, 2000). The results here are mixed - see for example the metastudy of Dimos and Pugh (2016). There is a small number of recent papers that have clearer causal identification strategies, but these papers tend to differ from ours in that they focus on single countries, different policy instruments, and different outcomes than those we focus on. For example, Jacob and Lefgren (2011) and Azoulay et al. (2019a) study the effect of NIH grants on publications and patenting; Bronzini and Iachini (2014) focus on the effect of R\&D subsidies on capital investment by Italian firms; Howell (2017) looks at Department of Energy SBIR grants on venture capital funding and patents; and Slavtchev and Wiederhold (2016) study the effect of government procurement on innovation. Guellec and van Pottelsberghe de la Potterie (2001) and Pless (2019) are rare exceptions that look at multiple types of R\&D policies.
} 
important de facto industrial policy used by the federal government to affect the speed and direction of innovation in the economy. The amount of public money flowing into defense R\&D dwarfs the amount spent on other prominent innovation policy tools in the US. For example, the total budget of the National Science Foundation or the overall value of the federal R\&D tax credit in a typical year are less than one tenth of federal outlays for defense-related R\&D (NSF 2006). Defense R\&D is the single most important component of government-funded R\&D in the UK and France as well, and a major component of government-sponsored $\mathrm{R} \& \mathrm{D}$ in many other developed economies.

We begin our empirical analysis using a unique dataset that we constructed by linking detailed information on defense-related and non-defense related government-funded R\&D to information on private $R \& D$, output, employment, and salaries in 26 industries in all OECD countries over 23 years. We estimate models that relate privately funded R\&D in a given country, industry, and year to government-funded $R \& D$ in the previous year, conditioning on a full set of country-industry and industry-year fixed effects.

We complement this industry-level analysis with a firm-level analysis based on a longitudinal sample of firms that engage in R\&D followed collected by the French Ministry of Research from 1980 to 2015. This is the only available dataset we know of that disaggregates public defense R\&D subsidies by firms across the whole economy. One advantage of using firm-level data is that we observe which firms within an industry actually receive public R\&D funds and which do not. The longitudinal nature of the data allows us to control for firm fixed effects, absorbing all time invariant unobserved differences across firms that may be systematically correlated with the propensity to invest in $\mathrm{R} \& \mathrm{D}$. We compare the same firm to itself in different moments in time and identification stems from the exact timing of the public R\&D award.

In both the OECD data and the French data, we use predicted defense R\&D as an instrumental variable to isolate exogenous variation in public $\mathrm{R} \& \mathrm{D}$. This instrument combines nationwide changes to defense R\&D with fixed allocations across industries. Annual aggregate changes in defense spending reflect political and military priorities that are largely independent of productivity shocks in different domestic industries. Wars, changes of government, and terrorist attacks have had major influences on defense spending. In the US, for example, military R\&D spending ramped up under President Reagan; fell back after the end of the Cold War, and rose again after 9/11. Importantly for our identification strategy, the impact that nationwide exogenous changes in military spending have on defense related 
R\&D varies enormously across industries, because some industries (e.g. aerospace) rely more heavily on defense-funding than others (e.g. textiles). ${ }^{2}$

The sign of the effect of government-funded R\&D on privately-funded R\&D could be positive or negative, depending on whether government-funded $R \& D$ crowds out or crowds in privately-funded R\&D. Crowding out may occur if the supply of inputs to the R\&D process (specialized engineers, for example) is inelastic within an industry and country (Goolsbee, 1998). In this case, the only effect of an increase in government-funded $R \& D$ is to displace private $R \& D$ with no net gains for total $R \& D$. Crowding in may occur if (i) R\&D activity involves large fixed costs and, by covering some of the fixed costs, government-funded R\&D makes some marginal private sector projects profitable; ${ }^{3}$ (ii) government-funded $\mathrm{R} \& \mathrm{D}$ in an industry generates technological spillovers that benefit other private firms in the same industry; and/or (iii) firms face credit constraints.

Empirically, we find strong evidence of crowding-in both the OECD and French datasets. Increases in government-funded $R \& D$ generated by variation in defense $R \& D$ translate into significant increases in privately-funded R\&D expenditures, with our preferred estimates of the elasticity equal to about 0.5. Our estimate implies that defense-related $R \& D$ is responsible for an important part of private R\&D investment in some industries. For example, in the US "aerospace products and parts" industry, defense-related R\&D amounted to $\$ 3,026$ million in 2002 (nominal). Our estimates suggest that this public investment results in $\$ 1,948$ million of additional private investment in $R \& D$. Considering the total amount spent by the US government, we estimate that private R\&D investment in the US is $\$ 85$ billion higher than the counterfactual with no government-funded defense R\&D. Using our estimates, we calculate that dollar-for dollar, publicly funded $R \& D$ generates twice as much overall R\&D compared to $R \& D$ tax credits.

Our estimates also indicate that cross-country differences in defense $R \& D$ might play an important role in determining cross-country differences in overall private sector R\&D investment. For example, we estimate that if France increased its defense R\&D to the level of the US as a fraction of its GDP (admittedly a large increase) private R\&D in France would increase by $10.3 \%$.

\footnotetext{
${ }^{2}$ The idea of using military spending as an exogenous component of government spending has been used in other contexts. In the analysis of fiscal multipliers Ramey (2011), Barro and Redlick (2011) and Nakamura and Steinsson (2014) have argued for the importance of using defense spending to mitigate endogeneity concerns. See also Perotti (2014).

${ }^{3}$ Examples of fixed costs include labs that can be used both for government-financed R\&D and for private R\&D or human capital investment in the form of learning by scientists on topics that have both military and civilian applications.
} 
We also find evidence of spillovers between countries. ${ }^{4}$ In the OECD data, increases in government funded $R \& D$ in one country appear to increase private $R \& D$ spending in the same industry in other countries. For example, an increase in government-funded R\&D in the US chemical industry induced by an increase in US defense spending in the chemical industry raises the industry's private R\&D in the US, but it also raises private R\&D in the German chemical industry. This type of crossborder spillover is consistent with the presence of industry-wide technological or human capital externalities.

In the final part of the paper, we turn to the effect of investment in R\&D on productivity. We estimate models where growth in TFP or output per worker is regressed on lagged private R\&D intensity, using predicted defense R\&D as a share of value added or sales as an instrumental variable. Industrylevel models based on OECD data indicate a positive effect of private R\&D on TFP. An increase in the defense $R \& D$ to value added ratio of one percentage point is estimated to cause an $8.3 \%$ increase in the yearly growth rate of TFP (e.g., from 0.98 percent per annum to 1.06 percent). OLS estimates from firmlevel models based on French data are qualitatively consistent with these findings, but IV estimates are imprecisely determined. ${ }^{5}$

We view this as a significant but not overwhelming effect. It suggests that a small fraction of US economic growth is accounted for by investment in defense R\&D. For example, defense R\&D in the US increased by a third between 2001 and 2004 following the 9/11 attack. We estimate that, holding taxes constant, this translated into a 0.005 percentage point increase of the annual TFP growth rate in the US in the affected years - about a $1.5 \%$ increase.

Overall, our estimates suggest that cross-country differences in defense R\&D play a role in explaining cross-country differences in private R\&D investment, speed of innovation, and ultimately in productivity of private sector firms. We caution that our estimates do not necessarily imply that it is desirable for all countries to raise defense R\&D across the board. Our finding that government-funded $R \& D$ results in increased private $R \& D$ does not necessarily imply that defense $R \& D$ is the most efficient way for a government to stimulate private sector innovation and productivity. There are other possible

\footnotetext{
${ }^{4}$ International spillovers of R\&D are studied by Hall, Mairesse, and Mohnen (2010); Coe and Helpman (1995); Pottelsberghe and Lichtenberg (2001); Keller (2004); and Bilir and Morales (2015).

${ }^{5}$ Consistent with the existence of international technology spillovers, we also uncover a positive effect of investment in R\&D in an industry and country on productivity of firms in the same industry but in different countries.
} 
innovation policies available to governments (see Bloom, Van Reenen and Williams, 2019, for a survey) and our analysis does not compare defense R\&D to other types of public R\&D spending.

The structure of the paper is as follows. Section 2 presents a simple framework and the empirical models. Section 3 describes the data. Sections 4 and 5 present the empirical results first on crowd-in and then on productivity. Section 6 concludes. Online Appendices detail the data (A); quantify alternative policies, such as the comparison with R\&D tax credits (B) and simulate the impact of the 9/11 shock (C).

\section{Conceptual Framework, Econometric Models and Identification Strategy}

We start with a simple framework that is useful in deriving the empirical models we take to the data, and in clarifying how to identify and interpret our empirical estimates. Here we focus on the effect of government-funded $R \& D$ on private $R \& D$ activity. Specifically, we are interested in the direct effect for an industry-country pair or a firm of receiving government-funded R\&D on the recipient's own private $R \& D$ investment. In addition, we are interested in international spillover effects that might arise if changes in government-funded $R \& D$ in a particular industry and country indirectly affect private $R \& D$ activity in the same industry in other countries. In Section 5, we will discuss the framework to estimate the direct and indirect effects of R\&D investment on productivity.

\subsection{Conceptual Framework}

We assume that output of firm $f$ in industry $i$ in country $k$ at time $t$ is a function of capital, $K$, labor, $L$, and intermediate inputs, $M$ :

$$
Y_{f i k t}=A_{f i k t} F\left(K_{f i k t}, L_{f i k t}, M_{f i k t}\right)
$$

where $A$ is Hicks-neutral TFP. Following the R\&D literature (e.g. Griliches, 1979) we assume that $A$ is determined by the lagged R\&D knowledge stock $G$ :

$$
\ln A_{f i k t}=\eta \ln G_{f i k(t-1)}+\gamma X_{f i k t}+u_{f i k t}
$$


where $\eta=\frac{\partial Y}{\partial G} \frac{G}{Y}$ is the elasticity of output with respect to the business R\&D stock, $X$ are other factors influencing TFP, and $u_{\text {fikt }}$ is a stochastic error term. The R\&D stock $G$ is an increasing function of privately funded R\&D expenditures $(R)$ and government-funded R\&D expenditures $(S)$.

We assume that $S$ is set by the government, while $R$ is chosen by the firm based on the technology embodied in equations (1) and (2), as well as on the cost of R\&D. We assume that the (static) demand for private $R \& D$ can be written as:

$$
\ln R=\sigma \ln U(S)+\beta \ln Y+v
$$

where $U$ is the Hall-Jorgenson tax-adjusted user cost of R\&D capital, which is allowed to depend on public subsidies, $S$ (see Criscuolo et al, 2019, for a discussion of how subsidies affect the user cost of capital). The user cost will also depend on current and expected interest rates, depreciation and the tax system as a whole (including R\&D tax credits). This equation can be rationalized as the steady state demand for R\&D from the first order conditions from specializing equation (1) to a CES production function (e.g. Bloom, Griffith, and Van Reenen, 2002). Under this interpretation, $\sigma$ is the elasticity of substitution and $\beta$ is the returns to scale parameter ( $\beta=1$ indicates constant returns) and $v$ is a function of technological parameters in the production function indicating factor biases. ${ }^{6}$

In our empirical analysis, we use two alternative datasets to estimate two variants of equation (3). In our analysis of OECD data, the level of observation is an industry-country-year and we assume that we can take a first order approximation of equation (3) as:

$$
\ln R_{i k t}=\alpha^{O E C D} \ln S_{i k(t-1)}+\beta^{O E C D} \ln Y_{i k t}+\lambda X_{k t}+d_{i k}+d_{i t}+v_{i k t}
$$

where the determinants of R\&D other than $S$ and $Y$ are assumed to be a vector of country by year observables $X_{k t}$, a set of industry by country fixed effects $\left(d_{i k}\right)$, industry by year dummies $\left(d_{i t}\right.$, e.g. industry specific product demand or technological shocks), and an idiosyncratic error $\left(v_{i k t}\right) .{ }^{7}$ In our

\footnotetext{
${ }^{6}$ If the production function was more general than CES, $v$ would also include other factor prices such as the wage rate.

${ }^{7}$ We include dummy variables to control for the country-industry fixed effects, which formally requires strict exogeneity of the right hand side variables. Since our panel is long (up to 26 years) we do not think there is likely to be much bias from this issue, but to check we also estimated the equation in first differences, which requires weaker exogeneity assumptions and obtained similar results.
} 
baseline models, $X_{k t}$ includes country-specific linear trends and GDP at t-1, thus controlling for countryspecific long run trends and business cycles as these demand side effects are likely to affect innovation (e.g. Shleifer, 1986). (The linear trends are not absorbed by the vector $d_{i t}$ because they are allowed to vary by country). In some specifications, $X_{k t}$ includes a country-specific quadratic trend and additional controls that may affect R\&D.

In our analysis of the French data, the level of observation is firm-years, and we assume that we can take a first order approximation of equation (3) as:

$$
\ln R_{f i t}=\alpha^{F R A} \ln S_{f i(t-1)}+\beta^{F R A} \ln Y_{f i t}+d_{f}+d_{t}+v_{f i t}
$$

where we include a set of firm fixed effects $\left(d_{f}\right)$ to absorb all sources of time-invariant heterogeneity across firms. Since in this specification we only have one country, we do not include $X_{k t}$ and $d_{i k}$ - these are absorbed by the time dummies and firm fixed effects respectively.

Equations (4) and (5) represent our baseline models in the empirical analysis of the effects of government R\&D on private R\&D. The focus of our analysis is on estimating the coefficients $\alpha^{O E C D}$ and $\alpha^{F R A}$ that relate changes in government-funded $\mathrm{R} \& \mathrm{D}$ in a given year to changes in private $\mathrm{R} \& \mathrm{D}$ in the following year. (Recall that the dependent variable is only the privately funded part of business R\&D, so there is no mechanical association between $R$ and $S$.)

Crowding in vs. Crowding Out. The sign of $\alpha$ is unknown a priori. If increases in governmentfunded R\&D crowd out private $R \& D$, the $\alpha$ terms should be negative. In the case of complete crowding out, the only effect of the policy is to displace private $R \& D$, with no net gain in total R\&D. This would be the case if, for example, the supply of inputs in the R\&D process in any given industry was perfectly inelastic in the short run. A key input in this respect is likely to be specialized scientists and engineers and the elasticity of their supply to a country-industry depends on their mobility across industries and countries. With inelastic supply to a country-industry, increases in public funds for R\&D come at the expense of declines in private $R \& D$. 
If, on the other hand, increases in government funded R\&D crowd in private $\mathrm{R} \& \mathrm{D}$, the $\alpha$ terms should be positive. In this case, more public R\&D stimulates even more private $R \& D$. There are at least three possible reasons for why this might be the case.

First, in the presence of large fixed costs, public R\&D may make marginal private projects feasible. In most industries, $R \& D$ activity is characterized by large fixed costs in the form of labs, research, human capital accumulation, set up costs, etc. It is realistic to think that some of these fixed costs can be used for multiple projects. For example, lab infrastructure set up for a specific project can, in some cases, be used for other projects as well. Similarly, a scientist's human capital acquired while working on a specific project - the intellectual understanding of a specific literature, for example, or her mastery of a scientific technique - can be helpful in other projects. By paying for some of the fixed costs, government-funded R\&D may make profitable for private firms' projects that otherwise would not have been profitable. Similarly, if government-funded R\&D results in process innovation, it is conceivable that this innovation can indirectly benefit private R\&D.

Second, if firms are credit constrained, the public provision of R\&D might relax these financial constraints. Although capital markets are generally well developed for the OECD countries we study, the special nature of R\&D investments highlighted by Arrow (1962), such as riskiness and asymmetric information, may make it especially vulnerable to financial frictions. ${ }^{8}$

Third, government-financed R\&D investment by one firm may make other firms in the same industry more productive because of technology or human capital spillovers (e.g. Moretti, 2004 and 2019). In this case, an increase in government-financed $R \& D$ directly raises $R \& D$ in the firm that receives the government contract, and may indirectly raise $R \& D$ in other firms in the same industry or same locality. Spillovers could also be negative in the case of strategic substitutability, as rival firms could free ride off the R\&D of the supported firms (e.g. Bloom, Schankerman, and Van Reenen, 2013).

An implication is that in the presence of $R \& D$ spillovers within an industry the estimated coefficient from industry-level data in equation (4) does not need to be identical to the coefficient from firm-level data in equation (5). Broadly, we expect industry coefficients should be larger if crowd-in induces rival firms to do more R\&D (due to strategic complementarity) or smaller if rivals do less $R \& D$ (due to strategic substitutability).

\footnotetext{
${ }^{8}$ See Garicano and Steinwender (2016) for some empirical evidence on financial frictions for R\&D.
} 
To account for the possible correlation of residuals in each year across industries in a given country and across countries in a given industry, standard errors for OECD data throughout the paper are multi-way clustered by country by industry pair and country by year pair (Miller, Cameron and Galbech, 2009). In the regressions based on the French data, we cluster at the 2-digit industry for industry-level regressions; and 3-digit industry for firm-level regressions.

\subsection{Identification}

There are at least two reasons why OLS estimates of equations (4) and (5) may be biased.

(a) First, government R\&D policies are unlikely to be random and may be set endogenously as a function of shocks to firms in the private sector. In particular, it is possible that government allocation of R\&D funding to specific industries or specific firms is correlated with determinants of private $R \& D$ investment.

Of course, equations (4) and (5) allow us to control for a wide variety of shocks that affect private R\&D and may also be correlated with government-financed R\&D. In equation (4), the inclusion of industry-year dummies accounts for the fact that different industries have different propensities to invest in $R \& D$, and these differences can vary over time as a function of technology shocks and product demand shocks. The inclusion of industry-country fixed effects accounts for differences in the propensity to invest in $R \& D$ across countries and the fact that these international differences may be more pronounced in some industries than others.

In equation (5), the vector of controls also include firm fixed effects. This is an important advantage of using firm-level data. It allows us to absorb all time-invariant unobserved differences across firms that may be systematically correlated with propensity to invest in R\&D. In equation (5), we compare the same firm to itself at different moments in time. Identification stems from the timing of the public R\&D award.

But even after conditioning on this rich set of controls, our models yield inconsistent estimates if the timing and amount of public R\&D is correlated with unobserved time-varying determinants of private R\&D. This may happen, for example, if governments tend to use public funds to help firms in sectors that are struggling and are experiencing declines in private R\&D. In this case, changes in public R\&D would be negatively correlated with unobserved determinants of private R\&D, introducing a negative bias in our estimates of the coefficient $\alpha$ in equations (4) and (5). The opposite bias arises if 
governments tend to use public funds to help firms in sectors that are thriving, and are experiencing increases in R\&D over and above those experienced by the same sector in other countries.

In either case, $S_{i k(t-1)}$ might be correlated with $v_{i k t}$ in equation (4) and $S_{f i k(t-1)}$ might be correlated with $v_{f i k t}$ in equation (5). If governments disproportionately help "winners", the correlation between $S_{i k(t-}$ 1) and $v_{i k t}$ (and $S_{f i k(t-1)}$ and $v_{f i k t}$ ) is positive and OLS overestimates the true effect. If governments disproportionately help "losers" (compensatory policies), the correlation between $S_{i k(t-1)}$ and $v_{i k t}\left(\right.$ and $S_{f i k(t-}$ 1) and $v_{f i k t}$ ) is negative and OLS overestimates the true effect. Note that in equation (4) what matters are industry-country specific time-varying shocks. Equation (4) is robust to industry specific time-varying shocks shared by all countries. For example, if the telecommunication industry is struggling in all countries, and governments decide to endogenously increase publicly funded R\&D for the industry, equation (4) would yield consistent estimates.

(b) A second possible reason why the OLS estimates of equations (4) and (5) may be biased is the presence of measurement error in our measure of public subsidies. In the presence of classic measurement error in $S$, attenuation bas may arise.

Instrumental Variable. To deal with these two issues, we use an instrumental variable that is a function of variation in defense R\&D subsidies. Defense R\&D is by far the largest component of government R\&D in many countries, e.g., United States, United Kingdom, and France. Defense R\&D also causes the biggest variations in public $R \& D$ over time, and there is a large variation across countries, ranging from pacifist countries like Japan or neutral countries like Austria, to defense-heavy countries like the United States and South Korea. This ensures that our instrument has a strong first stage.

Defense R\&D is usually motivated by geopolitical, not economic, considerations (Mowery, 2010), raising the possibility of using actual R\&D defense subsidies as the instrument for government funded $R \& D$. However, we are concerned that while most of the variation in defense R\&D is motivated by geopolitical considerations, variation in defense R\&D may also include an endogenous component. This would be the case if changes in the timing and amount of defense R\&D allocated to some industries and firms respond at least in part to shocks to the supply or demand of private R\&D in those industries or firms. For example, governments may allocate R\&D defense subsidies not based on purely military considerations but also as a way to foster employment and investment in specific sectors or firms. If defense $R \& D$ subsidies are correlated with unobserved determinants of private $R \& D$, an instrument 
based on defense R\&D would be invalid. While variation in R\&D defense subsidies is almost certainly more exogenous than variation in overall public $\mathrm{R} \& \mathrm{D}$, we can't rule out the existence of an endogenous component.

For this reason, we use predicted defense R\&D subsidies as instrumental variable instead of actual defense $R \& D$ subsidies. Predicted defense $R \& D$ subsidies isolate variation in defense $R \& D$ subsidies based on the combination of lagged defense R\&D subsidies to a given industry and the overall total defense $R \& D$ spending. The idea is that changes in overall $R \& D$ defense spending will impact some industries more than others, depending on their past share of defense R\&D spending. While the use of predicted instead of actual defense $R \& D$ subsidies may weaken the power of the instrument in the first stage, it strengthens its validity. In practice, our first stage has good power and is robust to various changes in the assumptions we use to construct the instrument.

The exact definition of predicted public defense R\&D differs slightly for the OECD and the French dataset due to differences in level of aggregation and variable definitions. The details on how we construct the instrument are in Appendix A.

a) OECD. For the OECD analysis, predicted defense R\&D subsidies $\left(D R_{i k t}^{I V}\right)$ is defined as

$$
D R_{i k t}^{I V}=\operatorname{share}_{i k(t-1)}^{l} \cdot \widetilde{d e f_{k t}}
$$

where $\widetilde{d e f_{k t}}$ is country $k$ 's total defense R\&D spending in year $t .{ }^{9}$ The term share ${ }_{i k(t-1)}^{l}$ is a weighted average of one-year lagged government defense R\&D in industry $i$ as a share of all the government defense R\&D in the United States and France. The weights are country-industry-time specific and depend on the similarity of country $k$ 's patent technology class distribution to the distributions of the United States and France. We use $\operatorname{share}_{i k(t-1)}^{l}$ rather than the actual own country share in order to further reduce the risk that the industry distribution of defense R\&D subsidies responds to expected country-specific shocks. Using the US and French data also has the practical advantage that defense R\&D subsidy data at the country-industry level by year is not available for the other countries. ${ }^{10}$

\footnotetext{
${ }^{9}$ This includes not only defense related R\&D subsidies spent by businesses, but also spend by sectors including e.g., universities (called "government budget appropriations or outlays on R\&D" or GBAORD by the OECD). We do not have aggregate numbers for the business sector only component for all OECD countries (only for France). In Table 3 we conduct robustness tests where we control for non-business R\&D to make sure our affects are not being driven by defense R\&D carried out in government labs or universities.

${ }^{10}$ The US industry shares are given for each fiscal year, so it is partially lagged compared to the other variables. It is available for the years 1987-2003 for the US (we hold the 2003 share constant for the years after 2003). Apart from the US, the defense
} 
Notice that since share $e_{i k(t-1)}^{l}$ is country-industry-year specific, it is not absorbed by any of our fixed effects.

Our identifying assumption is that variation over time in the amount of predicted defense-related R\&D experienced by a given industry in a given country is driven by shocks that are orthogonal to private R\&D shocks, such as wars, terrorism, geopolitical shocks like the end of the Cold War, and the ideological preferences of the political leaders in power.

It is possible that while the overall level of defense spending in a country is orthogonal to the residual $v_{i k t}$, the industry composition of defense spending may still be correlated with $v_{i k t}$. This would be the case if, for example, French defense spending declined after the end of the Cold War for exogenous reasons, but the decline was smaller in, say, aerospace, for endogenous reasons. Because we are using a weighted average of US and French industry shares for all countries, this is a problem only to the extent that endogenous adjustments to the industry shares reflect unobserved industry-specific time-varying shocks that are shared by the US, France and the relevant country. As tests of this we look at models that exclude the US or France (or both) and find that they all yield similar estimates.

We argued above that an additional motivation for using an instrumental variable is the possible presence of measurement error in the variable $\mathrm{S}$. We note that whatever measurement error exists in $\mathrm{S}$ in our OECD data, it is independent of the measurement error in defense R\&D and therefore in the instrumental variable. As explained in our data Appendix, the two variables come from different data sources so there is no mechanical correlation.

b) France. In the French analysis, the IV for firm-level models is defined as

$$
D R_{f t}^{I V}=\operatorname{share~}_{i 4} \cdot \widetilde{d e f_{l 3, t}}
$$

where share $_{i 4}$ is the annual share of defense R\&D subsidies allocated to firm $f$ 's main four-digit SIC industry (averaged across all years); and $\widetilde{d e f_{l 3, t}}$ is the level of defense subsidies defined at the threedigit industry level excluding subsidies going to firm $f$ itself in a particular year, to avoid a mechanical correlation between the IV and instrumented variable.

breakdown by industry is only available for France between 1980 and 2015 (see data description further below). Our results are robust to dropping either the US or France or both. We use only the France-specific data in the French firm-level analysis below. 
In some models, we perform an analysis at the three-digit industry level for France. In this case, we use the three-digit industry defense $R \& D$ share and the two-digit industry defense R\&D subsidy excluding the subsidy to firm $f$ 's three digit industry: share $i_{i 3} \cdot \widetilde{d e f_{l 2, t}}$. We tried using the US shares for the French analysis, but the level of coarseness of the aggregation of industry meant that the first stages were weak.

It is possible that government-funded R\&D by country $i$ is set endogenously in response to government-funded R\&D by country $i$ 's competitors. For example, an increase in government-funded R\&D in, say, the German chemical sector may induce France to increase its own government-funded R\&D in the chemical sector. This does not invalidate our estimates — even in an ideal randomized setting where public subsidies are randomly assigned this issue would arise — but it affects their interpretation. In this case, the $\alpha$ parameters should be interpreted as the effect of $S$ on $R$, after allowing for the endogenous reaction of other countries. This is arguably the parameter of interest for policy. It informs policymakers of what they can expect from a policy change is other countries react.

Product Demand Shocks. In both the OECD and French settings, a plausible concern is that shocks to predicted military R\&D could in principle signal shocks to future product demand. For example, an event such as 9/11 generated a direct increase in military R\&D, but also increased current and future demand for military products. In turn, this second channel could stimulate additional private R\&D through a demand or market size effect, thus invalidating our instrument. We note that it is not ex ante obvious that this is a major issue in our context because historically large increases in government defense procurement are typically targeted toward existing, rather than new technologies, while most $\mathrm{R} \& \mathrm{D}$ is likely to be directed at new technologies. ${ }^{11}$

We present four tests intended to probe the sensitivity of our findings to these demand effects. (i) As a first pass, we estimate models that condition on future industry output, as a measure of demand shifts. These models are not our preferred specification, because future output needs to be thought of as an endogenous variable. (ii) We then estimate models that condition on non-R\&D military spending and expectations thereof. (iii) We also estimate our baseline model solely on the US, where we have industryspecific R\&D and non-R\&D public military spending. (iv) Finally, we perform placebo tests based on

\footnotetext{
${ }^{11}$ This is why many historians like Milward (1977) have argued that wars tend to retard technological change by engendering a more conservative attitude to military procurement.
} 
components of defense spending that are unrelated to $R \& D$ subsidies paid to businesses. The idea is that our instrumental variable estimates should not be driven by changes in defense procurement that stimulate demand rather than R\&D. Overall, our findings indicate that changes in expected demand are not major sources of bias in our models.

Local Average Treatment Effect (LATE). An important issue to consider in interpreting our IV estimates is whether the effect of public R\&D is homogeneous or heterogeneous. Under the assumption of homogenous treatment effects, our IV estimates reflect the causal effect of public R\&D on private R\&D (if the IV is valid). On the other hand, if the effect of public R\&D is heterogeneous and it varies across firms and sectors, our IV estimates identify a particular Local Average Treatment Effect (LATE). In this case, the IV estimate of the treatment effect of government R\&D on private R\&D is reflective of the effect for compliers, which in our case are sectors and firms that receive an increase in government $R \& D$ because of an increase in defense $R \& D$, as opposed to other forms of public $R \& D$ subsidies. This raises the question of whether the effect for compliers is large or small—more precisely: whether defense R\&D has large or small effects on private R\&D compared to other government policies designed to subsidize private $R \& D$.

The magnitude of the effect of defense R\&D on private sector R\&D has long been debated (e.g., see surveys by Mowery, 2010, and Lichtenberg, 1995). Skeptics have argued that the effect of defense R\&D on private $R \& D$ is likely to be limited because the secrecy that surrounds defense R\&D inherently limits the scope of spillovers to civilian firms. By contrast, recipients of non-defense public R\&D subsidies are typically not subject to secrecy requirements and sometime may even be required to publicize their research. On the other hand, proponents of the benefits of defense R\&D for the private sector point to the commercial success of major innovations such as jet engines, computers, radar, nuclear power, semiconductors, GPS, and the Internet as evidence that military R\&D can trigger vast amounts of private R\&D investment directed to civilian applications. ${ }^{12}$

\footnotetext{
12 For example, see Lichtenberg (1984, 1988), Ruttan (2006), Mazzucato (2013) and the recent discussion of the DARPA model by Azoulay et al. (2019b). Draca (2013) estimates the impact of US defense spending on firm-level innovation and finds that increases in procurement contracts are associated with increases in patenting and R\&D. Bhattacharya (2021) presents a structural model of R\&D in the context of the US Navy SBIR program and Howell et al (2021) examine a reform to the US Air Force's SBIR program and has a survey of issues around military procurement and innovation. Some even argue that the Pentagon's role as the world's most generous investor in technological innovation during the Cold Warultimately resulting in superior technologies for American companies and enduring gains in their competitiveness (Braddon,
} 
For our purposes, if the effect on private R\&D for sectors and firms that experience an increase in government R\&D due to an increase in defense R\&D subsidies is larger (smaller) than the effect for sectors and firms that experience an increase in government R\&D due to an increase in non-defense R\&D subsidies, then our IV estimates may be larger (smaller) than our OLS estimates even if OLS estimates are unbiased.

\subsection{Employment and Wages}

We also examine the effect of increases in public R\&D investment on employment and wages. This is important because an increase in private $\mathrm{R} \& \mathrm{D}$ expenditures does not necessarily equal an increase in R\&D activity. We distinguish between the effect on labor market outcomes of R\&D workers and labor market outcomes of non-R\&D workers. If the supply of R\&D workers is completely inelastic in the short run, increased R\&D spending could simply result in higher wages, with little or no effect on employment and innovation (Goolsbee, 1998). On the other hand, if R\&D workers can move across industries or across countries so that supply to a specific country and industry is fairly elastic, we might find significant increases in R\&D personnel and limited increases in their wages. The effects on demand for non-R\&D personnel in the industry depend on whether R\&D generates technologies that substitute for or complement such labor. On the one hand, more R\&D in an industry may result in product innovation, higher sales, and therefore more labor demand. On the other hand, process innovation can easily reduce employment by making it easier to produce the same output with fewer labor inputs.

To empirically assess these questions, we estimate models where the dependent variable is the employment of R\&D workers, employment of non-R\&D workers, and average wages.

\subsection{International Spillovers}

It is in principle possible that increases in government-funded $R \& D$ in an industry in a given country affect private R\&D investment by firms in the same industry located abroad. For example, an increase in government-funded $R \& D$ in the German chemical industry may reduce private R\&D in the French chemical industry. This may be due to strategic reasons, as French firms decide it is not worth competing to catch up with their German rivals (e.g. international R\&D is a strategic substitute) or the cost of

1999) — was an important reason that US industries became so dominant. Proponents of this view often point to Israel as an example of how defense R\&D spending has resulted in high levels of private sector R\&D (e.g. Senor and Singer, 2009). 
internationally used industry-specific R\&D inputs (e.g. chemical engineers) may be driven up. The opposite spillover effect could also arise if R\&D is a strategic complement between countries, so that increased public R\&D in Germany results in French firms investing more to keep up in the race; or if there are significant cross-country technological or human capital externalities.

To empirically assess international spillovers, we use our OECD data to estimate models of the form:

$$
\ln R_{i k t}=\alpha^{O E C D} \ln S_{i k(t-1)}+\gamma^{O E C D} \ln S P_{i k(t-1)}+\beta^{O E C D} \ln Y_{i k t}+\lambda X_{k t}+d_{i t}+d_{i k}+v_{i k t}
$$

where $S P_{i k(t-1)}$ is a weighted average of government-funded R\&D in other countries in the same industry and year with weights measuring the between country $i$ and each other country: $S P_{i k(t-1)}=\sum_{j} d_{i j} S_{j k(t-1)}$ where $d_{i j}$ is the economic or geographic "distance" between country $i$ and country $j$ (normalized to sum to one for each country $i$ ) and $S_{j k(t-1)}$ is, as before, government-funded R\&D in industry $i$ in country $j$.

\section{Data and Basic Facts}

We use two separate data sets: section 3.1 details the data used in our OECD industry-country level analysis; section 3.2 describes the data used in our French firm-level analysis.

\subsection{OECD Industry-Country Data}

Data Sources. We combine data for OECD countries from the STructural ANalysis (STAN) dataset and the Main Science and Technology Indicators (MSTI) dataset. Our data include 26 countries, 26 industries, and 23 years, from 1987 to 2009. The Data Appendix describes in detail how we cleaned and merged the data and provides the exact definition of each variable with the corresponding source.

The definitions of R\&D are based on the internationally recognized "Frascati Manual" used by the OECD and national statistical agencies. Our main R\&D variable measures industry-level R\&D conducted by businesses (known as "Business Enterprise R\&D” or "BERD”).

We will generally refer to BERD as simply "R\&D” for brevity. While all BERD is conducted by firms, some of its funding comes from private sector sources while other funding comes from the government. Hence, in the notation of our model, $B E R D=R+S$.

- We refer to the part of BERD that is funded by private sources as "privately-funded R\&D," or “private R\&D." This is the variable $R$, the main dependent variable in equations (4) and (5). 
- We refer to the part of BERD that is funded by the government as "government-funded R\&D" or "public R\&D." This is the variable $S$.

- A subset of public R\&D is defense-related, and we refer to it as "defense R\&D." Note that $S$ only includes government-funded $R \& D$ conducted by private firms, and does not include $R \& D$ conducted by universities (and other non-profits) and by the government itself (e.g. in government R\&D labs). Also note that we do not have data on industry-specific defense R\&D in the OECD dataset, but we instead construct a predicted defense R\&D as described above. ${ }^{13}$ Appendix Table A1 (Panel A) summarizes the variable definition and presents summary statistics.

Facts about R\&D. There is wide variation in private $R \& D$, public $R \& D$, and defense $R \& D$ across countries, industries, and years. Consider first aggregate R\&D as a percent of GDP by country (Appendix Table A2). The most R\&D-intensive country is South Korea at 2.7\%, followed by Sweden at $2 \%$. The US also has a very high R\&D/GDP ratio of $1.9 \%$. At the other end of the spectrum, there are Southern European countries like Greece and Portugal, with ratios approximately $0.2 \%$. Although there appears to be a general upward trend in $\mathrm{R} \& \mathrm{D}$ over time, there is substantial variation across countries in growth rates, with some countries experiencing steep increases (e.g. Denmark) while others experience declines (e.g. the UK).

R\&D intensity also varies widely across industries (see Appendix Table A3). The most R\&Dintensive industries are generally Information Technology (Office, accounting, and computing machinery) and telecommunications (Radio, TV, and other communications equipment), with R\&D intensities of over $20 \%$. The next most R\&D intensive sectors are chemicals (including pharmaceuticals), medical/precision instruments, and transport equipment (including aerospace) with over 10\% of value added devoted to R\&D. By contrast there is very little formal R\&D in the distributive trades (wholesale and retail), personal services, and construction.

Public R\&D also varies widely across countries and over time. Table 1 shows that the US and Eastern European nations such as Poland and Slovakia have the highest share of R\&D funded by the government (over 15\%), whereas the share is under $2 \%$ in Switzerland and Japan. In many countries,

\footnotetext{
${ }^{13}$ The OECD also reports two other sources of funds: Other national and funds from abroad. These sources are small, with other national sources contributing to $0.01 \%$ of total R\&D, and sources from abroad contributing to $2.5 \%$ of total R\&D in the dataset. We add these funding sources to privately funded R\&D for simplicity, but our main results are not affected by this.
} 
such as the US, the UK, France, and Canada, the rate of public funding has decreased over time. Some of this is likely to be due to a shift from direct to indirect support to business R\&D, such as tax breaks (see Guellec and van Pottelsberghe de la Potterie, 1999). We explicitly add controls for tax incentives in robustness checks presented below. Table 2 shows the defense share of government-funded R\&D by country. Not surprisingly, the US has the highest proportion of defense-related R\&D (57\%), followed by Great Britain (35\%), and then France (29\%). In the data, we observe the defense-related part of the government's total R\&D budget from the OECD MSTI. ${ }^{14}$ Ideally, we would have just the governmentfunded and business-conducted part of $\mathrm{R} \& \mathrm{D}$, but this data does not exist over time across countries. It is likely that the two series track each other, however. ${ }^{15}$

The defense share of R\&D varies not just across countries, but also within country over time. This is important for the identification of our models, which include country by industry fixed effects. Figure 1 illustrates how the four largest economies in our data experienced very different developments in their shares of defense-related and government-funded R\&D to GDP ratios over time. In the United States, defense R\&D spending started at a very high level in the late 1980 s under Reagan (over $0.8 \%$ of GDP) and fell subsequently after the fall of the Berlin Wall in 1989. After 9/11, defense R\&D spending ramped up again under the War on Terror and the wars in Afghanistan and Iraq, rising from 0.45\% (in 2001 ) to $0.59 \%$ (in 2008) of GDP. In Germany, defense spending is at a much lower level. Like the US, Germany reduced defense spending after the Cold War, with the rise of President Gorbachev and the fall of the Berlin Wall. In 1996, however, Germany and France cofounded a military agency focusing on R\&D activities, causing a pick-up in defense R\&D in Germany. In contrast to the US, Germany did not ramp up defense spending after 9/11; instead, it continued to downsize its military (European Parliament, 2011). In stark contrast, Japan has an even lower level of defense R\&D spending, as its constitution commits the country to pacifism. However, Japan increased its military activities in response to North Korean missile tests in the late 1990s by starting a surveillance satellite program that resulted in satellite launches in 2003, 2006, and 2007 (Hagström and Williamsson, 2009). Finally, France shows a time-

\footnotetext{
${ }^{14}$ Specifically, "Total government funded R\&D" is all government budget appropriations or outlays of total R\&D, i.e., not just the government-funded part of R\&D conducted by businesses, but also the government-funded part of R\&D conducted outside of enterprises.

${ }^{15}$ Indeed, for the US and for France we have a more detailed breakdown and we confirm that the correlation is 0.73 (US) and 0.88 (France).
} 
pattern relatively similar to Germany: The reduction in defense spending after the end of the Cold War is visible, but in contrast to Germany, France did ramp up defense spending after 9/11.

Overall, the experiences of these four major economies with highly variable levels of defense $R \& D$ illustrate how the timing of changes in defense $R \& D$ often reflects factors that are largely exogenous to economic and technological conditions, being driven by geopolitical events that are heterogeneous across countries. ${ }^{16}$

Our instrumental variable strategy is predicated on the notion that defense R\&D is an important driver of overall government-funded R\&D. Figure 2 presents the series of defense $R \& D$ and public $R \& D$ by country (summed across industries). Clearly, in most cases the two series tend to move together: the average correlation is 0.29 (standard error 0.11 ). The importance of defense $R \& D$ varies widely across industries: Aerospace tends to be the single most important beneficiary of defense R\&D. In the OECD data the first stage of our IV relies on the relationship between public R\&D and predicted defense R\&D. The correlation at the industry level is visually strong (see Appendix Figure A1). In years when defense R\&D is high (low), overall government funded R\&D tends to be high (low). Below we quantify this relationship more formally.

\subsection{French Firm-level Data}

Data Sources. We use firm-level data collected by the French Ministry of National Education, Higher Education and Research ("Ministry of Research") in their annual R\&D survey from 1980 through 2015. The Data Appendix provides details on the survey that seeks to include all large firms that perform R\&D and a rotating sample of smaller firms that perform R\&D. Firms conducting research and development are asked to report detailed information on their R\&D activity (R\&D budget, number of R\&D employees, $R \& D$ wage bill, number of researchers), and broader firm information (such as their firm identifier - SIREN, total number of employees, sales, main industry, etc.). Importantly for us, the dataset includes information on which firms receive R\&D subsidies and how much, as well as what type of subsidy they receive (including defense). In the rest of the paper:

\footnotetext{
${ }^{16}$ Spain saw a rise in military spending after 1996, when the conservative center-right party came to power and pursued a new defense policy. The policy included a large increase in the military budget, which resulted in a sharp increase in military R\&D spending. The financial crisis in 2008 forced the government to significantly cut the military budget, including R\&D contracts (Miralles, 2004; Barbé and Mestres, 2007).
} 
- We refer to all R\&D subsidies originating from Ministry of the Armed Forces and its agencies as "defense R\&D subsidies."

- We refer to the sum of all R\&D subsidies (including defense $R \& D$ subsidies) originating from any ministry or government agency as "total R\&D subsidies" or just "R\&D subsidies."

- We refer to the firm's R\&D budget less total R\&D subsidies, other national funds, and international funds, as "privately funded R\&D."

Descriptive Statistics. The sample includes 40,787 firms for an average of 3.9 years each. Only $24 \%$ of firms appear in five or more years and almost $40 \%$ of firms appear just once. Since our models include firm fixed effects, we drop firms that appear only once. We also drop firms with missing R\&D data. The usable sample includes 12,539 firms appearing an average of 6.5 years each, 56\% of which appear in more than 5 years. Summary statistics are in Panel B of Appendix Table A1.

The largest two-digit industries by firm count in our sample are business services ( 8,025 firms) and software/data (7,507 firms), followed by machinery (2,755 firms). Because the survey targets firms that are likely to be conducting $R \& D$, this ordering also holds when we rank industries by number of firms conducting R\&D in one or more years: 7,112, 6,940, and 2,550 firms in business services, software/data, and machinery, respectively. Looking at the number of firms receiving R\&D subsidies, business services (3,118 firms), software/data (3,092 firms), and machinery (1,178 firms) remain the three most prominent industries. R\&D subsidies cover a large fraction of firms in these industries, while a much smaller portion receive defense R\&D subsidies: just 229 business services firms, 133 electronics firms, and 115 software/data firms over the 36-year period for which we have data.

While most R\&D subsidies are not for defense, most euros allocated via subsidies are for defense. Of the $€ 833$ billion in R\&D conducted in our sample, $€ 87$ billion was publicly funded, and $€ 57$ billion of that was targeted at defense. In industries like aerospace/transport, ${ }^{17}$ the dominance of defense subsidies is even clearer, with the industry conducting $€ 119$ billion in $R \& D$, of which $€ 38$ billion was publicly funded, almost $€ 31$ billion specifically for defense. Using the value of defense subsidies allocated to each industry, the largest defense industries after aerospace/transport are electronics, technical instruments, machinery, and chemicals.

\footnotetext{
${ }^{17}$ In addition to aerospace, this includes rail and ships, but not automobiles.
} 


\section{The Effect of Government-Funded R\&D on Privately-Funded R\&D, Employment and Wages}

We begin our empirical analysis by estimating the effect of publicly financed R\&D on privately financed R\&D (sub-section 4.1) and jobs and wages (sub-section 4.2). In sub-section 4.3, we estimate international spillover effects of R\&D.

\subsection{Effect of Public R\&D on Domestic Private R\&D}

\subsubsection{Estimates Based on OECD Data}

Table 3 presents estimates of the relationship between privately funded R\&D and lagged public $\mathrm{R} \& \mathrm{D}$ in the OECD industry-country panel. The dependent variable is R\&D conducted in the private sector (BERD) that is also financed by the private sector (recall that it excludes government financed R\&D). As discussed in the Data section, "Public R\&D" is government-financed R\&D performed by private firms. All columns control for a full set of country by industry fixed effects, a full set of industry by year dummies and a set of country-specific linear trends. Standard errors are two-way clustered at the industry-country and country-year level. All models are weighted by the industry-country pair's initial share of employment in total country employment.

Panel A reports OLS estimates. It shows that there is a statistically significant positive correlation between public $R \& D$ and private $R \& D$, more consistent with crowding in than crowding out. In Panel B, we report 2SLS estimates obtained by using predicted defense R\&D as an instrument for public R\&D. The first stages of our instrumental variable estimates are generally well identified. Weak instrument diagnostics are reported at the bottom and show that the instruments have good power: the F-Test (Kleibergen-Paap) ranges from 10.02 to 14.66 in our main specifications; and Anderson-Rubin Wald test rejects the null hypothesis of weak instruments in all columns.

Full first stage coefficients are reported in Appendix Table A4; these are interesting in their own right. A priori, it is unclear whether an increase in predicted defense R\&D in an industry will necessarily result in an increase in total government-funded R\&D in that industry. In theory, given a budget constraint, it is possible that increases in defense spending are offset by declines in non-defense subsidies, leading to no net effect on total public R\&D. The estimates in the table, however, suggest that this is not the case. A $10 \%$ increase in predicted defense R\&D is associated with a $0.9 \%$ to $1.01 \%$ increase in total government-funded $\mathrm{R} \& \mathrm{D}$, so there is not complete offset. 
The entry in column (1) in panel B of Table 3 indicates a positive effect of public R\&D on private R\&D. A $10 \%$ increase in public R\&D subsidies is associated with a $5.6 \%$ increase in the industry's privately funded R\&D spending in the following year. A comparison with panel A indicates that the point estimate is larger than the corresponding OLS estimate. This could indicate that subsidies are compensatory - targeted at "losers" and/or the presence of measurement error in public R\&D.

One possible concern is that changes in defense R\&D that are due to changes in the political orientation of a government might be correlated with changes in other policies that affect firms' private R\&D spending. For example, our model would be biased if, say, right-wing governments tend to both increase defense spending for specific sectors and simultaneously adopt pro-business policies for those sectors. In the rest of the table, we probe the robustness of our estimates to additional controls intended to capture variation in public policies. Since these additional controls are not always available, and our sample size declines from 5,026 to 4,459, in column (2) we replicate the model in column (1) using the smaller sample for comparison. The estimated coefficient falls slightly to 0.492 (0.199).

In column (3) we add controls for industry output and national GDP; the coefficient on public R\&D increases slightly to 0.518 (0.204). Recall that our models condition on country-specific linear trends. Adding country-specific quadratic trends to absorb non-linear drifts in each country would result in significantly larger estimates of the effect of Public R\&D. For example, the estimated IV coefficient from the model in column (3) is 0.780 (0.244) (results available on request).

In column (4), we add a measure of R\&D tax credits based on data from Thomson (2012). R\&D tax credits are an alternative form of government support for R\&D used by a number of countries. Over the past 20 years, many governments have started to replace direct R\&D subsidies with other fiscal policies such as R\&D tax credits (Guellec and van Pottelsberghe de la Potterie, 1999; Moretti and Wilson, 2012). From the point of view of governments, publicly funded R\&D and R\&D tax credits are likely to be substitutes, making it possible that in practice the two types of public support are negatively correlated. In this case, our estimates might understate the true effect of government-funded R\&D. In practice, the magnitude of this bias is unlikely to be large, since R\&D tax credits are in most countries part of the national tax code, and unlike the direct R\&D subsidies, they are not industry-specific. Empirically, the coefficient on public R\&D in column (4) appears to decrease to 0.476 (0.190).

Besides businesses, other institutions like universities and government-funded research labs receive subsidies for $R \& D$, which might be correlated with business R\&D subsidies. In column (5) we 
also include R\&D subsidies to non-business institutions. Empirically, non-business R\&D does not appear to affect private R\&D undertaken by businesses significantly, and the coefficient on public R\&D rises slightly. R\&D subsidies might also be correlated with other business favoring policies, for example taxes on businesses, which might also affect private R\&D directly (e.g. Akcigit et al, 2018). In column (6) we control for business tax revenues as a proportion of GDP (tax revenue data is from OECD and includes taxes on income, profits and capital gains of corporates). There is a weakly negative effect of taxes, but the point estimate on public R\&D subsidies is robust to this addition.

As an additional robustness check on the role played by government policies we estimate a model that controls for the political orientation of the government. If R\&D subsidies are correlated with other government policies, this is likely to be especially true for the case when defense R\&D changes are due to changes in the political orientation of the government after elections. ${ }^{18}$ Columns (1) and (2) in Appendix Table A5 indicate that the estimated effect of public R\&D appears unchanged, indicating that variation in industry-specific defense R\&D is not highly correlated with the general political orientation of governments.

As discussed above, an important concern is that increases in defense R\&D spending might be correlated with increases in expected future demand for output. For example, after 9/11, US firms producing aircraft may have anticipated increased demand for military planes and increased private R\&D in expectation of this greater demand, even in the absence of public R\&D. This would violate our identification assumption, as both public and private R\&D respond to an exogenous event. While some specifications in Table 3 condition on industry and aggregate output and industry by time dummies, these variables may not fully account for expectations of future demand changes that are specific to an industry-country pair.

We seek to address this concern in four ways. As a first pass, in columns (3) and (4) of Appendix Table A5, we show robustness to conditioning on future industry output. These models are not our preferred specification, because future output needs to be thought of as an endogenous variable. Second, in columns (5) and (6) of Appendix Table A5, we use only country*year variation in the defense instrument. These estimates ignore variation across industries and are identified only by variation across countries and time in defense expenditures. While the first stage is a bit lower, the estimated coefficients

\footnotetext{
${ }^{18}$ The political orientation data is from the World Bank's Database of Political Institutions (DPI) and indicates whether the chief executive's party is right wing, center, or left wing.
} 
are not very much affected. Thirdly, in columns (7) and (8) of Appendix Table A5, we estimate models that condition on non-R\&D military spending and expectations thereof. The sample size drops to 2,108 since we do not have data on total public military spending for all countries but the estimates based on the sub-sample where we do have this information are similar to the baseline estimates in Table 3. Including total military spending does not significantly affect the coefficients on public R\&D.

Finally, in Appendix Table A6, we perform placebo tests based on components of defense spending that are unrelated to R\&D subsidies paid to businesses: defense procurement excluding R\&D; and military wage bill excluding R\&D (either using a narrow or a broad definition of R\&D, so overall there are four placebo instruments). Changes in both defense procurement excluding R\&D and military wage bill excluding R\&D are likely to be correlated with changes in demand, but should not result in changes in $R \& D$. Therefore, in models where public $R \& D$ or private $R \& D$ is regressed on defense procurement or military wage bill, the four placebo instruments should not be predictive of public or private R\&D. Finding a significant correlation between the placebo instruments and public or private R\&D would suggest that our IV estimates might be driven by demand effects coming from defense spending other than $R \& D$, or by a correlation of defense spending with other policies that encourage economic growth and therefore R\&D. The results in Appendix Table A6 indicate that measures of nonR\&D defense procurement and non-R\&D military wage bill are uncorrelated with public and private R\&D.

Overall, while we cannot completely rule out that future demand expectations play a role in our estimates, the weight of the evidence appears to be more consistent with the effects of public R\&D on private R\&D reflecting forces of supply rather than demand.

We performed numerous additional robustness tests. Since our models are identified by changes in public $\mathrm{R} \& \mathrm{D}$ over time, one might be concerned that the results are driven by countries with very low defense R\&D levels. If we re-estimate our model only including countries with above-median defense R\&D to GDP ratios-US, France, UK, South Korea, Sweden, Spain, Germany, Slovakia, Italy —our estimates appear robust. The OLS and IV coefficients of the same specifications as in column (3) in Table 3 are $0.160(0.026)$ and 0.694 (0.328), respectively. We also checked for outliers by (i) winsorizing observations in the top and bottom $1 \%$ of the level of the private R\&D distribution and (ii) winsorizing observations in the top and bottom $1 \%$ of the changes in the private R\&D distribution. Additionally, we tried winsorizing the growth rates of the IV. The results are robust to all these modifications. 
Finally, we note that our baseline model has linear country time trends but not a full set of country by year dummies. The reason is that the first stage is weak if country-year fixed effects are included, reflecting the fact that much of the variation in the instrument is at the country-year level. The addition of country-year dummies makes little difference to the OLS results, especially once we include GDP to account for macroeconomic shocks. ${ }^{19}$

\subsubsection{Estimates Based on French Data}

Table 4 contains the estimates for the French dataset. Compared to the estimates based on the OECD data, the firm-level French data allow for a much finer level of detail, since we observe which firms within an industry actually receive public R\&D and which do not. In terms of identification, firmlevel data allow us to estimate models that include firm fixed effects, therefore accounting for all timeinvariant heterogeneity across firms. Identification comes from comparing the level of private R\&D in the same firm observed before it receives a government R\&D subsidy and after it receives a government R\&D subsidy.

Panel A presents the industry-level results for France and panel B presents the firm-level results. We present industry-level results for comparison to the OECD industry-country data in Table 3, although it should be noted that the French data allow for a finer degree of industry disaggregation (195 sectors). Column (1) of panel A shows the OLS estimates. The coefficient suggests a positive correlation between privately funded business R\&D and lagged government subsidies, but is smaller in magnitude than the OECD results in Table 3. Column (2) reports the corresponding IV estimate using defense spending predicted from more aggregate industry trends as an instrument for defense R\&D subsidies. The first stage F-statistic is $\mathrm{F}=11.56$. (All first stage coefficients are reported in Appendix Table A7). The IV estimate is significant and much larger than the OLS estimate, just like the OECD results. The IV coefficient of 0.346 is not significantly different from the comparable OECD coefficient of 0.511 in column (2) of Table 3 Panel B ( $\mathrm{p}$-value of difference $=0.20$ ).

Recall that defense spending at the industry level is not available in OECD industry data for most countries, but we do have it in France. Consequently, we include it directly on the right hand side of the private R\&D equation in the columns (3) and (4) of Table 4. The coefficient on defense subsidies is

\footnotetext{
${ }^{19}$ For example, in the third column of Panel A in Table 3, the coefficient (standard error) on public R\&D increases slightly to 0.167 (0.028) when country by year fixed effects are included.
} 
positive and significant for the OLS and IV specifications, although again the IV coefficient is larger: $0.150(0.041)$. Note that a $10 \%$ increase in total subsidies is obviously a larger amount of money than a $10 \%$ increase in defense subsidies alone, which explains the smaller elasticity in column (4) compared to $(2)$.

The firm-level analysis in panel B is based on a longitudinal sample of 12,586 firms observed for several years, for a total sample size of 81,201 firm-years. Panel B shows similar patterns to the results in panel A. In column (2), the IV coefficient is 0.119 (0.069), while in column (4), it is 0.374 (0.215). The IV estimates again lead us to reject the null of crowd-out: increases in public R\&D result in more investment in private $R \& D$, not less. Based on entries in column (2), a $10 \%$ increase in $R \& D$ subsidies is associated with a $1.2 \%$ increase in the firm's privately funded $R \& D$ spending in the following year. This confirms that even after controlling for firm fixed effects, defense R\&D subsidies appear to be crowding in private $R \& D$ spending.

A comparison with panel A of Table 4 indicates that industry-level coefficients are smaller than firm-level coefficients when we use defense R\&D subsidies (columns (3) and (4)), but the reverse is true for total R\&D subsidies (columns (1) and (2)). Coefficients from industry-level data do not need to be identical to coefficients from firm-level data in the presence of technology spillovers from R\&D within an industry. Industry coefficients should be larger if crowd-in induces rival firms to do more R\&D (strategic complementarity). However, it might be that rivals do less R\&D if there is strategic substitutability (e.g. free riding), for example, meaning that industry coefficients would be less than their firm-level counterparts (Bloom, Schankerman, and Van Reenen, 2013). We will investigate spillover effects at the international level in more detail below.

OLS vs. IV. Overall, there is little evidence of upward bias in the OLS estimates in Tables 3 and 4. In fact, the OLS estimates are consistently below the IV estimates. In the context of our discussion in Section 2, there are three possible non-mutually exclusive explanations. First, this finding is consistent with compensatory government policies, whereby governments tend to subsidize industries that are underperforming in terms on R\&D investment (see the discussion in Rodrik, 2007, for example). For example, Criscuolo et al. (2019) find evidence of compensatory policies in the case of UK investment subsidies. In our data, there is some evidence that public R\&D policies tend to be compensatory in OECD countries. To see whether public $R \& D$ subsidies tend to be directed toward industries that are struggling 
or thriving, we used our OECD data to estimate simple VAR models that relate changes in public R\&D to changes in industry output in a given country and year (controlling for changes in country GDP). Results for models with ten lags are in Appendix Figure A2. Panel A indicates that public R\&D subsidies increase after a negative industry output shock. While this evidence needs to be interpreted merely as suggestive, it appears more consistent with compensatory government policies. By contrast, Panel B shows that industry output reacts positively to lagged public R\&D subsidies, as we would expect.

Alternatively, the finding of IV estimates being larger than OLS estimates may reflect local average treatment effects. Recall that in case of heterogeneous effects, our IV estimates reflect the treatment effect of government $R \& D$ on private $R \& D$ for compliers. If the effect of defense $R \& D$ on private $R \& D$ is larger than the effect of non-defense $R \& D$, as suggested by part of the literature, then our IV estimates will be larger than the corresponding OLS estimates, even if the OLS estimates are unbiased.

Finally, the finding may also reflect attenuation bias from measurement error.

\subsubsection{Magnitude of the Estimated Effect}

Taken together, the estimates in Tables 3 and 4 indicate that increases in public R\&D translate into increases in private $\mathrm{R} \& \mathrm{D}$ expenditures. This is true both when we focus on industry changes across the whole OECD or within France and when we focus on within-firm changes in France. This crowd-in is consistent with the existence of agglomeration economies-whereby increases in government R\&D raise the returns for private companies in the same country and industry—or large fixed costs or credit constraints.

Our preferred elasticity for the OECD dataset is 0.518 (Table 3, panel B, column (3)), suggesting that a $10 \%$ increase in government subsidies in a given year is expected to result in a $5.1 \%$ increase in private sector $R \& D$ the following year. Our preferred elasticity at the firm level in the French dataset is 0.119 (Table 4, panel B, column (2)). At the mean values of public and private R\&D in France, this implies that $€ 1$ of additional public funds for R\&D translates into $€ 0.85$ of extra $R \& D$ funded by the private sector. As noted above, the smaller firm level effects compared to industry level effects could be due to positive within industry spillovers.

Our findings imply that in some industries, defense-related R\&D is responsible for a significant portion of private R\&D investment. For example, in the US "aerospace products and parts" industry, 
defense-related R\&D amounted to \$3,027 million in 2002 (nominal). Our estimates suggest that this public investment results in $\$ 1,948$ million of additional investment in private $R \& D .{ }^{20}$ If we take the total amount spent by the US government, we estimate that private R\&D investment is $\$ 85$ billion higher than the counterfactual with no government-funded defense R\&D.

Interestingly, differences in defense-related R\&D can account for some of the differences in private R\&D across countries. For example, our estimates indicate that if France increased its defense R\&D to the level of the US as a fraction of GDP (admittedly a very large increase: roughly a factor of $2.2)$, private $R \& D$ investment would increase by $10.3 \% .^{21}$

Finally, we compare public R\&D subsidies to $R \& D$ tax credit policies. We consider the impact on total R\&D of abolishing the US tax credit and reallocating the saved public funds to direct government grants. ${ }^{22}$ On the most recent data, the federal tax credit costs $\$ 11.3$ billion. Using the user-cost elasticity of unity in Table 3, we estimate that the credit raises R\&D by $\$ 14.2$ billion. By comparison, the crowdin elasticities of Table 3 imply that spending the $\$ 11.3$ billion saved from abolishing tax credits on grants would raise total $R \& D$ by $\$ 30.7$ billion. This is over twice as much as the effect generated by $R \& D$ tax credits. Appendix B provides the details of these calculations, considers a range of robustness tests and concludes that direct grants are likely no worse value for money than tax incentives and generally seem to perform better. There is, of course, great uncertainty over these back of the envelope calculations, but we do think they are useful for understanding the order of magnitude of the effects of alternative innovation policies.

\subsection{Effect on Employment and Wages}

Appendix Table A8 reports estimates of models similar to those in Tables 3 and 4 where the dependent variable is employment or wages. For convenience, column (1) reproduces the baseline effect

\footnotetext{
${ }^{20}$ Public R\&D in aerospace products and parts amounted to $\$ 4,306$ million in 2002 (nominal). Therefore, defense related R\&D was $70 \%$ of public R\&D. A reduction of public R\&D by $70 \%$ translates into a reduction of private R\&D by $36 \%$ using our preferred elasticity of 0.518 in column (3) of Table 3. Private R\&D was $\$ 5,349$ million in aerospace products and parts in 2002 , so $36 \%$ of this number yields $\$ 1,948$ million.

${ }^{21}$ Our estimates also indicate that if Germany increased its defense R\&D to the level of the US as a fraction of GDP (an even larger increase), private R\&D investment would increase by $72 \%$. Defense R\&D expenditure as share of GDP in our data (averaged over all years) is $0.58 \%$ for the US, $0.28 \%$ for France, and $0.07 \%$ for Germany. To reach the defense R\&D share of the US, Germany would have to increase own defense R\&D spending by a factor of 9.3 - a very large increase. Multiplying this with the coefficients of the first stage and the IV estimates yields the estimated percent increase in private R\&D spending. ${ }^{22}$ Other thought experiments are possible. But this one sidesteps the issue of what is the impact of R\&D on productivity and what is the distorting effects of raising public funds.
} 
of public R\&D on private R\&D from column (1) of Table 3 (OECD data) and columns (1) and (2) of Table 4 (French data). Since data on employment and wages are not available for all countries and industries and years, column (2) reports the baseline elasticity estimated on the sample for which employment and wage data are available. In column (3), the dependent variable is the number of workers directly engaged in R\&D activities; in column (4) it is the number of workers not engaged in $R \& D$ activities; and in column (5) it is the average salary of R\&D workers -- measured as the cost of R\&D personnel over divided by R\&D personnel. The top panel reports OLS estimates, while the bottom panel reports IV estimates.

OLS estimates using the OECD data uncover significant elasticities of employment of R\&D workers and the average salary of R\&D workers and significant positive but much smaller elasticities on the employment of non-R\&D workers. The large employment effects and smaller wage effects for R\&D workers are consistent with an elastic labor supply, possibly indicating that it might be easy for R\&D workers to relocate to the affected industry from other industries or countries.

For France, the estimated elasticities on employment of R\&D workers in column (3) are similar to those for R\&D expenditures in column (2), indicating that employment of French scientists increases proportionally to increases in R\&D expenditures. At the same time, the employment effects are much larger than the wage effects, indicating a more elastic labor supply of researchers from possibly abroad compared to the average OECD country.

IV estimates for France 3-digit industries have a similar pattern as OLS estimates, but estimates based on OECD data and French firm level data are too imprecise to draw firm conclusions.

\subsection{International R\&D Spillover Effects}

So far, we have estimated the direct effect of government-funded R\&D in an industry and country on private $R \& D$ activity in the same industry and country. We now consider the possibility that government-funded R\&D in an industry and country may have an additional, indirect effect on private R\&D investment in other countries. It is possible that increases in government-funded R\&D in an industry in a given country will result in lower R\&D in similar industries abroad. Alternatively, knowledge generated from public R\&D in one country may spill over to a different country and generate additional private research efforts. To quantify these spillover effects, we estimate equation (6) where 
we include both domestic public R\&D and neighbors' public R\&D. We base this analysis on the OECD industry-country data.

Specifically, in panel A of Table 5 we regress private $R \& D$ on lagged domestic public $R \& D$ and lagged neighbors' public R\&D, measured as a weighted average of public R\&D in other countries in the same industry and year, with weights reflecting various measures of geographic and economic proximity. Column (2) uses the difference in GDP per capita as a distance measure, column (3) the geographic distance in kilometers between the capital cities, column (4) the difference in skill intensity as measured by the share of the population with tertiary education, column (5) the similarity of patent technology classes (out of 15 different technology classes), column (6) the difference in R\&D intensity as measured by $R \& D / G D P$. We instrument domestic public R\&D but not neighbors' public R\&D, which we assume to be exogenous to domestic firms. (The corresponding OLS coefficients are in Appendix Table A9).

The effect of domestic public $R \& D$ on private $R \& D$ remains positive across all specifications. The coefficient of interest is the one on neighbors' public R\&D. It is positive and statistically significant in all columns but (4) which uses skill intensity, indicating that if one country increases its public R\&D, firms in nearby countries in the same industry increase their investment in private R\&D after controlling for public $R \& D$ received from their own government. The positive effect is consistent with significant crowd-in between close countries when proximity is defined by income, geography, technology, FDI flows, and R\&D intensity. The estimated elasticities range from 0.151 (0.053) in column (2)-where proximity is based on per-capita GDP - to $0.909(0.211)$ in column (5) - where proximity is based on technology.

Panel B uses business R\&D (not government-funded R\&D) to compute the international spillover pool to test whether private $R \& D$ undertaken in a foreign country can also generate spillover effects. Here the coefficients in columns 5 and 6 are negative, providing evidence of international displacement between firms that are technological close or have similar R\&D intensity. The coefficients in the other columns are not statistically different from zero. Private R\&D investment by firms in an industry and country appear to have either no effect, or in some cases to discourage competitors in the same industry in other countries from undertaking their own R\&D.

In panel $\mathrm{C}$ we include both international public $\mathrm{R} \& \mathrm{D}$ and international business $\mathrm{R} \& \mathrm{D}$ simultaneously. In all but one specification, elasticities on international public R\&D are positive while elasticity on international private $R \& D$ are negative and significant. The elasticities on the international 
public R\&D and international private R\&D appear of the same order of magnitude in absolute value, indicating that they have a quantitatively similar percentage effect, although of opposite sign.

Overall, we conclude that private and public R\&D generate rather different spillover effects on R\&D behavior. While there are positive spillover effects from public R\&D subsidies, private R\&D leads to either no spillover effects or crowding out. One possible explanation could be the fact that governmental subsidies may be associated with requirements to make research findings public; or that research supported by the government tends to be more basic research.

\section{The Effect of R\&D on Productivity}

Having documented the effect of government-funded R\&D on private R\&D investment, we now turn our attention to quantifying the effect of R\&D investment on productivity. We start in sub-section 5.1 by deriving the econometric model that we use in our empirical analysis. In sub-section 5.2 we present estimates of the effect of total R\&D on domestic productivity based on industry-level OECD data and firm level French data. We also present estimates of international spillovers based on OECD data - namely, the effect of R\&D performed in an industry and country on productivity in the same industry but in different countries. We conclude in sub-section 5.3 with an illustration of the magnitude of the effects implied by our estimates based on the $9 / 11$ shock.

\subsection{Econometric Models}

We relate measures of productivity to $R \& D$ investment. In the OECD data, we measure productivity as industry-country-year TFP. We approximate $F($.$) in equation (1) above by a second order$ flexible form and can therefore estimate TFP as the superlative index:

$$
\Delta \ln A_{i k t}=\ln \left(\frac{V A_{i k t}}{V A_{i k(t-1)}}\right)-\frac{1}{2}\left(\theta_{i k t}+\theta_{i k(t-1)}\right) \ln \left(\frac{L_{i k t}}{L_{i k(t-1)}}\right)-\left(1-\frac{1}{2}\left(\theta_{i k t}+\theta_{i k(t-1)}\right)\right) \ln \left(\frac{K_{i k t}}{K_{i k(t-1)}}\right)(7)
$$

where $V A_{i k t}$ is value added, $L_{i k t}$ is total employment, and $K_{i k t}$ is the capital stock. We measure $\theta$ using labor's share of value added in two ways. First, we simply use the industry-specific average of the share (across all countries and years). ${ }^{23}$ Alternatively, we use Harrigan (1997) smoothing methods to construct

\footnotetext{
${ }^{23}$ Since our TFP estimates are at the industry level, this method is more suited to estimate productivity than alternative methods such as Olley-Pakes (1996) or Levinsohn-Petrin (2003) which are designed for estimation at the level of the firm.
} 
the share of labor in value added, $\theta_{i k t}$. Both methods give very similar results. The Data Appendix describes in more detail how we estimate TFP. To estimate the effect of R\&D on TFP at the industry level, we assume that the total R\&D stock can be described by the perpetual inventory formula: $G_{i k t}=$ $R_{i k t}+S_{i k t}+(1-\delta) G_{i k(t-1)}$ where $\delta$ is the depreciation rate of knowledge. If $\delta$ is close to zero, the TFP growth equation can be approximated by:

$$
\Delta \ln A_{i k t}=\rho\left(\frac{R+S}{V A}\right)_{i k(t-1)}+\gamma \Delta X_{i k t}+\Delta u_{i k t}
$$

where $\rho=\frac{\partial Y}{\partial G}$ is the gross rate of return to $\mathrm{R} \& \mathrm{D}$ capital. ${ }^{24}$

In the French firm-level data, we have no information on capital stock or value added. Thus, our dependent variable is labor productivity defined as output per worker, $\left(\frac{Y}{L}\right)_{f i k t}$ :

$$
\Delta \ln \left(\frac{Y}{L}\right)_{f i k t}=\rho\left(\frac{R+S}{Y}\right)_{f i k(t-1)}+\Delta u_{f i k t}
$$

Equations (8) and (9) focus on the direct effect of a country's R\&D investment on its own productivity. It is possible that there is an additional indirect effect in the form of an international technological spillover. This would occur if a country's investment in a given industry ends up benefitting the productivity of firms in different countries due to international knowledge spillovers. To test for this possibility, we use our OECD data to estimate a variant of equation (8):

$$
\Delta \ln A_{i k t}=\rho((R+S) / V A)_{i k(t-1)}+\kappa(R P / V A)_{i k(t-1)}+\gamma \Delta X_{i k t}+\Delta u_{i k t}
$$

where $(R P / V A)_{i k(t-1)}$ is the weighted average of $\mathrm{R} \& \mathrm{D} /$ value added in all other countries in the same industry and year, with weights measuring the economic or geographic distance of country $k$ to all other countries (as in the spillover variable in equation (6)). A positive (negative) $\kappa$ would indicate the existence of positive (negative) international technological spillovers.

\footnotetext{
${ }^{24}$ Although conventional, assuming $G_{i k t}=R_{i k t}+S_{i k t}+(1-\delta) G_{i k(t-1)}$ is restrictive. We considered an alternative specification $G_{i k t}=R_{i k t}+\mu S_{i k t}+(1-\delta) G_{i k(t-1)}$ that allows a dollar of public R\&D to have a different effect on the knowledge stock than a dollar of private R\&D. This implies including two separate R\&D terms on the right hand side of equation (8). The problem is that this requires an additional instrument for privately funded R\&D. We considered using R\&D tax credits, but the first stage had insufficient power when both public and private R\&D were taken as endogenous.
} 
In practice, variation in value added and output per worker reflect both variation in physical productivity as well as variation in the prices of output. This is a common problem in the estimation of production functions. In our context, this problem is likely to be serious because shocks to the demand for defense products (geopolitical shocks, leadership changes, etc.) are likely to results in shocks to the price of defense-related products. The defense industry is highly concentrated and has significant barriers to entry, at least in the short run. This means that the supply curve is almost certainly not infinitely elastic in the short run. An upward sloping supply curve implies that when product demand increases, our measure of TFP increases even if productivity does not change. As standard in this literature, we deal with this problem by using industry-year specific price deflators. ${ }^{25}$

\subsection{Effect of R\&D on Productivity}

In Table 6, we estimate equations (8) and (9) by regressing changes in productivity on lagged total R\&D intensity. Total R\&D is measured as the sum of private R\&D $(R)$, public $\mathrm{R} \& \mathrm{D}(S)$ and $\mathrm{R} \& \mathrm{D}$ from any other source. Columns (1) to (4) are based on OECD industry-level data (equation (8)). Columns (5) and (6) are based on the French firm-level data (equation (9)).

The OLS coefficient on R\&D of column (1) indicates a positive correlation between lagged R\&D intensity and subsequent TFP growth. Column (2) adds country dummies and shows that the coefficient is essentially the same as in column (1). We find a similar coefficient of 0.097 (0.031) for the IV estimate in column (3), which is not statistically different from the OLS estimate. Column (4) reports the reduced form estimate. In this model the independent variable is defense R\&D divided by value added, which has a both positive and statistically significant effect. ${ }^{26} \mathrm{We}$ conduct a similar exercise for French threedigit industries in column (5). The OLS estimate is positive, just like the one for the OECD industrycountry panel, but of smaller magnitude-0.026 (0.004). In column (6) we repeat this exercise on the French firm-level data. We uncover a coefficient (standard error) of 0.040 (0.004), a bit larger than the corresponding industry-level elasticity. Unfortunately, the IV estimates corresponding to columns (5)

\footnotetext{
${ }^{25}$ This is more problematic for the firm level results when there are firm-specific prices. In this case the coefficient on R\&D includes an effect on markups as well as quantity-based productivity.

${ }^{26} \mathrm{We}$ probed the robustness of our finding using several alternative specifications. For example, estimates of the impact of R\&D on TFP using Harrigan (1997) smoothing techniques are very similar: the equivalent coefficient (standard error) on R\&D intensity in column (3) was 0.089 (0.032).
} 
and (6) are unidentified as the first stages have insufficient power (the F-statistics at the industry and firm level are 0.96 and 0.10 respectively). ${ }^{27}$

The magnitude of the estimated effects in Table 6 is economically significant. Using the estimate for the OECD industry-country panel in column (4), for example, a permanent increase in the predicted defense $R \& D$ to value added ratio of one percentage point is associated with an increase in the annual growth rate of TFP of 0.08 percentage points. Since average annual TFP growth in our sample is around $0.98 \%$, this represents an increase from $0.98 \%$ to $1.06 \%$ a year (i.e., an increase by $8.3 \%$ ). Using the OLS estimate in column (5), a similar calculation suggests an increase from an average annual labor productivity growth rate of $0.05 \%$ to $0.076 \%$ a year in France.

To put this in perspective, consider that our estimates indicate that if France and Germany were to raise their defense spending to the level of the US as a percentage of value added - holding constant everything else and ignoring the additional tax revenues needed - they would experience an increase in the productivity growth rate by $3 \%$ and $5 \%$, respectively. ${ }^{28}$

The finding of a positive effect on productivity has an additional implication for our earlier analysis of crowding in. The estimated positive effects on productivity indicate that the positive crowding in effects that we found in the previous section are unlikely to be driven only by a relabeling of other expenditure as R\&D expenses in order to obtain subsidies. A pure relabeling would not result in measurable productivity increases.

Finally, we turn to the question of international productivity spillovers. We estimate equation (10), where we use the same set of weights used in Table 5. Findings in Appendix Table A10 indicate statistically significant positive international spillovers with coefficients ranging between $0.188(0.068)$ and $0.304(0.070)$ in the IV specifications. In order to interpret the magnitude note that the average values of own $\mathrm{R} \& \mathrm{D} /$ value added and the international spillover pool are different, so the coefficients cannot

\footnotetext{
${ }^{27}$ The lack of first stage power in this table stands in contrast with strong first stages in the previous tables. A possible reason is that the first stage does not include firm fixed effects (otherwise the second stage would be effectively in double differences). This suggests the changes in firm R\&D and changes in firm defense public may be more strongly related than the level relationship.

${ }^{28}$ The average defense R\&D to value added ratios for the US, France, and Germany in our data are $0.53 \%, 0.30 \%$, and $0.08 \%$, respectively. Thus, France would need to increase its defense R\&D/value added by $74 \%$, while Germany would need a $603 \%$ increase.
} 
directly be compared. The effect of the spillover pool is larger because it requires all the other countries to increase their public R\&D. ${ }^{29}$

\subsection{An Illustration of the Magnitude of the Effects: The 9/11 Shock}

We end with an illustration of the magnitudes of various effects arising from our analysis based on a concrete example: the increase in military R\&D that occurred in the US after the 9/11 attacks. As described in Figure 1, US defense R\&D rose by $52 \%$ bringing it from $0.45 \%$ to $0.60 \%$ of GDP between 2001 and 2004. Using all the linkages in the results above, we calculate that the $9 / 11$ shock induced an increase of the TFP growth rate by 0.005 percentage points, holding taxes constant. Since the average annual growth rate in this period is $0.4 \%$, this effect amounts to a $1.5 \%$ increase. We view this effect as significant but not exceedingly large. In addition, TFP growth in other OECD countries is estimated to rise by $0.028 \%$ on average. We provide a detailed explanation of how we quantified these effects in Appendix C. In short, the effect on US TFP growth comes from using the TFP estimate in Table 6, column (3), combined with an increase in total US R\&D/GDP of 0.06 percentage points (or 2.9\%; which is composed of public R\&D rising by $4.8 \%$ according to Table $A 4$, column (3), and private $R \& D$ rising by $2.5 \%$ according to the IV results of Table 3 , column (3), due to crowding in). The effect on other OECD countries comes from the international spillover arising from the increase in US R\&D (Table A10). There is also a small TFP offset because US R\&D displaces some foreign R\&D (down $-0.02 \%$ on average; Table A11).

In interpreting these estimates, three points need to be highlighted. First, our estimates quantify the TFP gains occurring within a relatively short horizon. It is likely that the effects are larger when looking at a longer time horizon, e.g. over decades, therefore our estimates are likely to underestimate the true effect of public R\&D subsidies on private $R \& D$ and productivity growth. Second, we only examine within industry productivity effects. To the extent there are inter-industry spillovers, we again underestimate the productivity benefits. Third, these estimates do not account for the opportunity cost of public funds needed to finance the increase in public R\&D. In reality, the US government faces a budget

\footnotetext{
${ }^{29}$ For example, in a specification using geographical distance weights for spillovers, the own R\&D coefficient is 0.004 and the spillover coefficient is 0.237 (Table A10, column (3)). An increase by one standard deviation of own R\&D/value added (14.8 percentage points) is associated with future TFP growth by $0.04 \%$. By contrast, an increase by one standard deviation of the spillover pool (5.8 percentage points) increases TFP growth by $0.85 \%$. Note that the coefficient on domestic R\&D falls and becomes insignificant when spillovers are included which is due to the fact that domestic and international R\&D are highly correlated, so it is difficult to estimate both effects simultaneously.
} 
constraint, and the increase in public expenditures on R\&D needs to be thought of as coming either from a decrease in other forms of public expenditures or as an increase in current or future taxes, or a combination of both. In either case, the opportunity cost of the additional public R\&D expenditures induced by $9 / 11$ is unlikely to be zero, although it is difficult to estimate in practice. ${ }^{30}$

Overall, our estimates need to be interpreted as partial equilibrium estimates of an increase in public R\&D (see Akcigit, Hanley and Stantcheva, 2017, for example for a general equilibrium approach).

\section{Conclusions}

Our results suggest that government R\&D "crowds in" rather than "crowds out" private R\&D using industry and firm level longitudinal data. In addition, we find evidence that an increase in public R\&D in one industry and country raises private $R \& D$ in the same industry in other countries through a positive spillover effect. Finally, we uncover significant but not overwhelming effects of private R\&D investment on TFP growth and therefore economic growth.

In terms of policy implications, our estimates point to a specific tool that governments can use to raise private $R \& D$ investment in their jurisdiction. Our estimates indicate that government-funded $R \& D$ in general - and defense R\&D in particular — are effective at raising a country's total expenditures on innovation in a given industry. The ultimate effect of government-funded $R \& D$ on overall $R \& D$ significantly exceeds its dollar value because government-funded R\&D stimulates additional R\&D investment on the part of the private sector. This positive effect of government-funded R\&D on private R\&D is important not just in itself, but because it generates higher productivity. This of course does not imply that it is efficient to raise defense R\&D or government-funded R\&D across the board, since government-funded R\&D clearly has an opportunity cost in the form of taxpayer money used plus any welfare loss that inevitably comes from taxation. Our paper does not compare the benefits of government-funded R\&D to its costs.

Our findings also indicate that the benefits of public R\&D investment do not stop at a country's borders, but spillover to other countries. This implies that countries that spend aggressively on government funded R\&D-like the US - indirectly support the productivity of countries with less

\footnotetext{
${ }^{30}$ The opportunity cost could be high if it cut other forms of public expenses with high returns or if the expected increase in taxes crowd out private investment. Alternatively, the opportunity costs could be low if the federal government financed the increase in public R\&D by cutting unproductive or wasteful public expenses. For example, military procurement is widely considered inefficient and ripe with waste and rent seeking.
} 
government-funded R\&D. This externality indicates the desirability of more international cooperation in government-funded R\&D.

\section{References}

Aghion, Philippe and Peter Howitt (1992) "A Model of Growth through Creative Destruction” Econometrica, 60(2), 323-51

Akcigit, Ufuk, Douglas Hanley, and Stephanie Stantcheva (2017) “Optimal Taxation and R\&D Policy.” NBER Working Paper 22908.

Akcigit, Ufuk, John Grigsby, Tom Nicholas and Stephanie Stantcheva, S. (2018) "Taxation and Innovation in the 20th Century." NBER Working Paper No. 24982.

Arrow, Kenneth (1962) "Economic Welfare and the Allocation of Resources for Invention" in The Rate and Direction of Inventive Activity: Economic and Social Factors, 609-626

Azoulay, Pierre, Joshua Zivin, Danielle Li, and Bhaven Sampat (2019a) "Public R\&D Investment and Private Sector Patenting: Evidence from NIH Funding Rules" Review of Economic Studies, 86(1), 117-152.

Azoulay, Pierre, Erica Fuchs, Anna Goldstein and Michael Kearney (2019b) "Funding Breakthrough Research: Promises and Challenges of the ARPA Model", in Innovation Policy and the Economy, Volume 19, Josh Lerner and Scott Stern (eds)

Barbé, Esther and Laia Mestres (2007) "Spain and ESDP”, in: Brummer, Klaus (Ed.) The South and ESDP, Gütersloh.

Barro, Robert and Charles J. Redlick (2011) "Macroeconomic Effects from Government Purchases and Taxes" Quarterly Journal of Economics, 126(1), 51-102

Bhattacharya, Vivek (2021) "An Empirical Model of R\&D Procurement Contests: An analysis of the DOD SBIR Program”, forthcoming, Econometrica

Bilir, L. Kamran and Eduardo Morales (2015), "The Impact of Innovation in the Multinational Firm," mimeo

Bloom, Nick, Rachel Griffith and John Van Reenen (2002) "Do R\&D tax credits work? Evidence from a panel of countries 1979-1997" Journal of Public Economics 85(1), 1-31

Bloom, Nick, Mark Schankerman and John Van Reenen (2013) "Technology Spillovers and Product Market Rivalry" Econometrica, 81 (4), 1347-1393

Bloom, Nicholas, John Van Reenen and Heidi Williams (2019) "Policies to Promote Innovation", Journal of Economic Perspectives, 33(3), 163-184

Braddon, (1999) "Commercial Applications of Military R\&D: US and EU Programs Compared", mimeo, University of the West of England

Bronzini, Raffaello and Eleonora Iachini (2014) "Are Incentives for R\&D Effective? Evidence from a Regression Discontinuity Approach", American Economic Journal: Economic Policy, 6(4), 100-134

Caves, Richard, Laurent Christensen and Erwin Diewert (1982) "The economic theory of index numbers and the measurement of input, output and productivity", Econometrica, 50, 6, 1393-1414

Coe, David T. and Elhanan Helpman (1995) "International R\&D Spillovers". European Economic Review 39(5), 859-887

Congressional Research Service (2018) Government Expenditures on Defense related R\&D by the US and other OECD Countries Washington DC https://fas.org/sgp/crs/natsec/R45441.pdf 
Criscuolo, Chiara, Ralf Martin, Henry Overman and John Van Reenen (2019), "Some causal effects of an industrial policy" American Economic Review 109(1) 48-85

David, Paul, Bronwyn Hall and Andrew Toole (2000) "Is public R\&D a complement or substitute for private R\&D? A review of the econometric evidence" Research Policy, 29(4-5), 497-529.

Dechezlepretre, Antoine, Elias Einio, Ralf Martin, Kieu-Trang Nguyen and John Van Reenen (2019), "Do Fiscal Incentives increase innovation? An RD Design for R\&D” CEP Discussion Paper 1413

Dimos, Christos and Geoff Pugh (2016) "The effectiveness of R\&D subsidies: A meta-regression analysis of the evaluation literature" Research Policy, 45, 797-815

Draca, Mirko (2013) "Reagan's innovation dividend? Technological impacts of the 1980s US defense build-up." CAGE Working Paper Series No. 168.

European Parliament (2011) "The Impact of the Financial Crisis on European Defense", Annex.

Garicano, Luis and Claudia Steinwender (2016) "Survive another day: Using changes in the composition of investments to measure the cost of credit constraints", Review of Economics and Statistics, 98(5), 913-924.

Goolsbee, Austan, (1998) "Does Government R\&D Policy Mainly Benefit Scientists and Engineers?" American Economic Review, 88(2), 298-302.

Griliches, Zvi (1979) "Issues in Assessing the Contribution of Research and Development to Productivity Growth" Bell Journal of Economics, 10(1), 92-116.

Griliches, Zvi (1992) “The search for R\&D spillovers”, Scandinavian Journal of Economics, 94, 29-47

Guellec, Dominique and Bruno Van Pottelsberghe de la Potterie (2001) "R\&D and Productivity Growth :

Panel analysis of 16 countries" OECD Economic Studies, 33, 103-126

Hagström, Linus and Jon Williamsson (2009) '“'Remilitarization,' Really? Assessing Change in Japanese Foreign Security Policy" Asian Security, 5(3), 242-272.

Hall, Bronwyn (1993) "R\&D Tax Policy during the 1980s: Success or Failure?" Tax Policy and the Economy, 7, 1-36

Hall, Bronwyn and Jacques Mairesse and Pierre Mohnen (2010), "Measuring the Returns to R\&D," CIRANO Working Papers 2010s-02, CIRANO.

Harrigan, James (1997) “Technology, Factor Supplies, and International Specialization: Estimating the Neoclassical Model," American Economic Review, 87(4), 475-94.

Howell, Sabrina (2017) "Financing Innovation: Evidence from R\&D Grants." American Economic Review, 107(4), 1136-64.

Howell, Sabrina, Jason Rathje, John Van Reenen and Jun Wong (2021) "Opening up Military Innovation: Causal Effects of 'Bottom-Up' Reforms to U.S. Defense Research” NBER Working Paper 28700

Jacob, Brian and Lars Lefgren (2011) "The impact of research grant funding on scientific productivity", Journal of Public Economics, 95(9-10), 1168-1177

Keller, Wolfgang (2004): “International Technology Diffusion” Journal of Economic Literature, 42(3), 752-782.

Kline, Patrick, Neviana Petkova, Heidi Williams and Owen Zidar (2019) "Who Profits from Patents? Rent-Sharing at Innovative Firms" Quarterly Journal of Economics, 134 (3), 1343-1404

Lach, Saul (2002) "Do R\&D subsidies stimulate or displace private R\&D? Evidence from Israel" Journal of Industrial Economics, 50, 369-90

Levinsohn, James and Amil Petrin (2003) "Estimating Production Functions Using Inputs To Control For Unobservables" Review of Economic Studies, 70(2) 317-341 
Lichtenberg, Frank (1984) "The Relationship between Federal Contract R\&D and Company R\&D” American Economic Review 74(2) 73-78.

Lichtenberg, Frank (1988) "Assessing the Impact of Federal Industrial R\&D Expenditure on Private R\&D Activity in the U.S." in The Relation Between Defense and Civil Technologies, Philip Gummett and Judith Reppy (eds) Dordrecht: Kluwer Academic Publishers, 68-87.

Lichtenberg, Frank (1995) “The Economics of Defense R\&D”. In Hartley, K and Sandler, T. (eds) Handbook of Defense Economics, Volume 1. Elsevier: New York.

Mazzucato, Mariana (2013) The Entrepreneurial State: Debunking Public vs. Private Sector Myths, Anthem Press

Miller, Douglas, Colin Cameron and Jonah Galbech (2009) "Robust Inference with Multi-way Clustering" UC Davis Discussion Paper 09

Milward, Alan (1977) War, Economy and Society Berkeley: University of California Press

Miralles, Débora (2004) "The European Security and Defense Policy under Aznar's administration," Observatory of European Foreign Policy, Special Issue: Spain in Europe 1996-2204, EE10/2004.

Moretti, Enrico (2004) "Workers' Education, Spillovers and Productivity: Evidence from Plant-Level Production Functions", American Economic Review 94(3)

Moretti, Enrico (2019) “The Effect of High-Tech Clusters on the Productivity of Top Inventors" NBER WP

Moretti, Enrico and Daniel Wilson (2014) "State Incentives for Innovation, Star Scientists and Jobs: Evidence from Biotech", Journal of Urban Economics, 79: 20-38.

Mowery, David (2010) "Military R\&D and Innovation" in Bronwyn Hall and Nate Rosenberg (eds) The Handbook of the Economics of Innovation, Volume 2. Elsevier, London.

Nakamura, Emi and Jón Steinsson (2014) "Fiscal Stimulus in a Monetary Union: Evidence from US Regions" American Economic Review, 104(3): 753-792

National Science Foundation (2006) National Patterns of R\&D Resources (Annual Series). Division of Science Resources Statistics, Washington DC

National Science Foundation (2020) National Patterns of R\&D Resources: 2017-18 Data Update, January 8 2020, https://ncses.nsf.gov/pubs/nsf20307/

National Science Board. (2018). Science \& Engineering Indicators. Retrieved from https://www.nsf.gov/statistics/2018/nsb20181/assets/nsb20181.pdf

OECD (1999) ISDB 98, International Sectoral Data Base, User's Guide, OECD, Paris.

OECD (2010) Measuring Innovation: A New Perspective, OECD, Paris.

Olley G. Steven and Ariel Pakes (1996) "The Dynamics of Productivity in the Telecommunications Equipment Industry" Econometrica 64(6) 1263-1297

Perotti, Roberto (2014) "Defense Government Spending Is Contractionary, Civilian Government Spending Is Expansionary" NBER Working Paper No. 20179

Pless, Jacqueline (2019) “Are 'Complementary Policies' Substitutes? Evidence from R\&D Subsidies in the UK" MIT mimeo

Pottelsberghe De La Potterie, Bruno Van and Frank Lichtenberg (2001). "Does Foreign Direct Investment Transfer Technology Across Borders?" Review of Economics and Statistics, 83(3), 490497.

Ramey, Valerie (2011) "Identifying Government Spending Shocks: It's All in the Timing”, Quarterly Journal of Economics, 126(1), 1-50 
Rao, Nirupama (2016) "Do tax credits stimulate R\&D spending? Revisiting the effect of the R\&D tax credit in its first decade." Journal of Public Economics, 140, 1-12

Rodrik, Dani (2007) One Economics, Many Recipes, Princeton: Princeton University Press

Romer, Paul (1990) “Endogenous Technological Change," Journal of Political Economy, 98(5), 71-102.

Ruttan, Vernon W. (2006) Is War Necessary for Economic Growth? Military Procurement and Technology Development Oxford: Oxford University Press

Scarpetta, Stefano and Thierry Tressel (2002) "Productivity and Convergence in a Panel of OECD Industries: Do Regulations and Institutions Matter?" OECD Economics Department Working Papers 342, Paris: OECD Publishing.

Sengupta, Somini “The Pentagon as Incubator", New York Times, 8/23/2013.

Senor, Dan and Saul Singer (2009) Start-up Nation, Washington DC: Council on Foreign Relations.

Shleifer, Andrei (1986) "Implementation Cycles" Journal of Political Economy 94 (6): 1163-1190.

Slavtchev, Viktor, and Simon Wiederhold (2016) "Does the Technological Content of Government Demand Matter for Private R\&D? Evidence from US States." American Economic Journal: Macroeconomics, 8(2): 45-84.

Thomson, Russell (2012) "Measures of R\&D tax incentives for OECD countries", mimeo, Melbourne Institute of Applied Economic and Social Research

Van Reenen, John (1996) "The Creation and Capture of Rents: Wages and Innovation in a Panel of U.K. Companies," Quarterly Journal of Economics, 111(1), 95-226.

Wallsten, Scott (2000) "The effects of government-industry R\&D programs on private R\&D: the case of the Small Business Innovation Research program" RAND Journal of Economics, 31, 82-100. 


\section{APPENENDICES FOR ONLINE PUBLICATION ONLY UNLESS REQUESTED BY EDITORS}

\section{APPENDIX A: DATA}

\section{(A1) OECD DATA}

Main Variables. R\&D data was obtained from the OECD database Main Science and Technology Indicators (MSTI). This dataset contains industry level R\&D conducted by businesses ("Business Enterprise R\&D" or "BERD") for 26 countries between 1987 and 2009. This is our main R\&D variable, but note that BERD is the main component of general R\&D ("GERD") which also includes R\&D conducted by non-businesses such as universities and government R\&D labs (it is not possible to break this down by industry).

The panel is unbalanced as some data is not available for some countries especially in the early years. Note that BERD is R\&D conducted by business but can be financed from several sources. The OECD breaks BERD into three sources of funding: government, business and abroad. Our main variable is BERD that we generally refer to simply as "R\&D". The variable "Public R\&D" is the government funded part of BERD $(S)$. We used the OECD's PPP US\$ values to deflate all nominal variable such as GDP, output and R\&D. From the same dataset, we also obtained the total number of R\&D personnel by industry and country (all measured in full-time equivalent on R\&D activities) which is broken down into scientists ("\# researchers") and other R\&D personnel such as lab technicians. We also have the total wage bill of these R\&D personnel that enables a crude construction of the "R\&D wage" of R\&D labor cost divided by total R\&D personnel.

For the main regressions where we use $R \& D$ as the dependent variable, we use the industryfunded part of BERD as the dependent variable. We refer to this as "private R\&D" $(R)$. For the regressions where we use TFP growth as the dependent variable, we use R\&D as the key right hand side variable - i.e. total BERD from all sources of funds. We take output, employment, wage bill, capital and value added data from the OECD STAN database. We use the level of industry aggregation that maximized the matches between the databases STAN and MSTI, ending up with 26 industries (see below).

Data for missing years was linearly interpolated for all variables (between the first and the last year available per country), but no data was extrapolated forward or backwards. These imputations accounted for between zero and $35 \%$ of the final sample, depending on the variable. The results are robust to dropping interpolated values.

The industry level breakdown of BERD by source of funding was missing for the United States after 2001 in the MSTI because a change in industry classification of the OECD (to ISIC Rev. 3) required a new crosswalk from the industry classification used in the US, NAICS. However, we obtained the original R\&D data from the National Science Foundation, Survey of Industrial Research and Development (SIRD), and implemented the crosswalk to our data set, verifying that the totals (all source of funds) by industry matched the totals published by the MSTI. The crosswalk is available on request.

Total Factor Productivity, TFP. TFP growth can be measured by a superlative index derived from the translog production function (as in Caves et al, 1982). This results in the following expression for industry-country-year TFP:

$$
\Delta \ln A_{i k t}=\ln \left(\frac{V A_{i k t}}{V A_{i k t-1}}\right)-\frac{1}{2}\left(\theta_{i k t}+\theta_{i k t-1}\right) \ln \left(\frac{L_{i k t}}{L_{i k t-1}}\right)-\left(1-\frac{1}{2}\left(\theta_{i k t}+\theta_{i k t-1}\right)\right) \ln \left(\frac{K_{i k t}}{K_{i k t-1}}\right)
$$

where real $V A_{i k t}$ is value added, $L_{i k t}$ is total employment, $K_{i k t}$ is the capital stock, and $\theta_{i k t}$ is the share of labor in value added. 
Value added is from the STAN database, we use the variable VALK that gives value added in volumes. STAN uses volume indices provided by national statistical agencies that are typically derived by applying detailed deflators based on Producer Price indices (PPIs) or Consumer price indices (CPIs) coming from detailed surveys. Volumes for activity groups are either fixed-weight Laspeyres aggregates or annually re-weighted chained aggregates of the volumes of detailed sectors.

Capital stock is given in STAN in variable CPGK, "gross capital stock (volumes)". For some countries (e.g. US, Japan, Australia, Norway, Sweden) the capital stock was not available in the STAN database, but investment data was (variable "GFCK", gross fixed capital formation in volumes). For these countries, we follow Scarpetta and Tressel (2002) and OECD (1999) and construct capital stock using a perpetual inventory model, which simulates the process of capital accumulation using past investment data that is adjusted for scrapping. Gross capital stock $G C S_{t}$ at time $t$ is:

$$
G C S_{t}=\sum_{j} I N V_{t-j} *\left(1-\delta_{j}\right)
$$

where $I N V_{t-j}$ is investment undertaken in period $t$-j, i.e. with vintage $j$ at time $t$, and $1-\delta_{j}$ is the survival coefficient that represents the fraction an investment of vintage $j$ that is still in use in year $t$ contributes to gross capital stock in year $t$. The survival coefficient is between 0 and 1 , and falls with vintage. We follow the literature and assume that depreciation follows a delayed linear retirement pattern, where scrapping starts only 5 years after the investment has been undertaken.

Average services lives (ASL) are usually used to measure the depreciation process of an investment. If depreciation starts after 5 year and is linear, ASL is given by

$$
A S L=5+\frac{n}{2}
$$

where $n$ is the time period during which an investment has positive depreciation (and $n+5$ is the total lifetime of an investment). Thus, with linear depreciation, in each year depreciation equals a constant fraction $\delta$ of past investment (starting after 5 years):

$$
\delta=\frac{1}{n}=\frac{1}{2 *(A S L-5)}
$$

Gross capital stock can therefore be constructed using the recursive relationship:

$$
G C S_{t}=G C S_{t-1}+I N V_{t}-\frac{1}{2 *(A S L-5)} \sum_{j \geq 5} I N V_{t-j}
$$

Since our investment data starts only at the beginning of the sample period and we need past investment for the construction of gross capital stock, we assume that past, unobserved annual investment is equal to average investment across the sample years (separately for each industry within each country). Our results are robust to assuming past investment to be equal to initial observed investment, or average investment across the first observed years. This assumption about past investment can then also be used to calculate the gross capital stock at the beginning of the sample period. Average services lives (ASL) by country and industry are given in OECD (1999), p. 48. For countries without ASL data, we use the US industry-specific ASL.

The share of labor in value added is measured in two ways. First, we simply used the industryspecific unweighted average of the wage bill over value added (across all countries and years). Alternatively, we use the Harrigan (1997) smoothing method to construct the share of labor in value added $\alpha_{i k t}$, by industry, country and year. For this, we ran a pooled OLS regression of the form 


$$
\theta_{i k t}=\theta_{i k}+\phi_{j} \ln \left(\frac{K_{i k t}}{L_{i k t}}\right)
$$

where $\theta_{i k t}$ is the observed labor share in value added, $\alpha_{i k}$ are a full set of industry-country pair fixed effects and $K$ and $L$ are capital stock and employment as described above. We then used the predicted values from this regression for the industry-country-year specific share of labor in value added $\theta_{i k t}$. As robustness checks we also used the overall average labor share in our data, or a constant labor share of 0.65 to construct TFP, but our results were not sensitive to the specification of the share of labor in value added.

\section{(A2) French Data}

We use data collected by the French Ministry of National Education, Higher Education and Research (which for brevity we will refer to as "Ministry of Research") for their annual R\&D survey from 1980 through 2015. Firms conducting research and development activity are asked to report detailed information on their R\&D performance - R\&D budget, number of R\&D employees, $R \& D$ wage bill, number of researchers - and broader firm information-SIREN (firm ID), total number of employees, sales, main industry. The survey seeks to include all large firms that perform R\&D and a rotating sample of smaller firms that perform R\&D. In particular, firms with R\&D expenditures above a threshold are surveyed every year, while a rotating sample of firms below the threshold is surveyed for two consecutive years. The threshold varies over time. For example, in 2007 is was $€ 250,000$ and by 2011 it was raised to $€ 400,000$. For our purposes, the net effect is that there is significant turnover in the sample that we work with among the smaller firms. We observe 40,787 firms an average of 3.9 years each. Almost $40 \%$ of firms appear just once; and only $24 \%$ appear in five or more years. Missing R\&D data and our empirical strategy (firm fixed effects) reduce the usable sample to 12,539 firms appearing an average of 6.5 years each, approximately $56 \%$ of which appear in more than five years. Overall, our sample over-weights large firms that conduct significant amount of R\&D.

We observe 40,787 firms an average of 3.9 years each. However, almost $40 \%$ of firms appear just once; and only $24 \%$ appear in five or more years. Missing R\&D data and our empirical strategy (firm fixed effects) reduce the usable sample to 12,539 firms appearing an average of 6.5 years each, approximately $56 \%$ of which appear in more than five years.

Defense R\&D subsidies. Importantly, the survey asks about R\&D subsidies granted under the authority of individual ministries, i.e. Ministry of Research or Ministry of the Armed Forces. We treat all $R \& D$ subsidies originating from Ministry of the Armed Forces and its agencies as defense R\&D subsidies.

Total R\&D subsidies. We define total $R \& D$ subsidies as the sum of all $R \& D$ subsidies (including defense R\&D subsidies) originating from any French ministry or government agency.

Privately funded R\&D. We call the firm's R\&D budget less total R\&D subsidies privately funded R\&D.

Industry classification. During this period French industry codes change three times (in 1993, 2003, and 2008) so we use a combination of correspondence mappings and crosswalks, created from firms surveyed under multiple classification systems, to harmonize all 4-digit industry codes to the NAF revision 1 classification in use from 2003-2008. We have 689 4-digit industries, 2163 -digit industries, and 594 -digit industries.

In addition to the variables mentioned above, we also use information on firm sales and employment. In our data the mean (median) sales and employment for a firm-year are $€ 260$ million (€19.8 million) and 925 (129) workers. Similarly, in 2000 prices, the mean (median) firm-year receives 
$€ 576,000$ (€0) in defense R\&D subsidies, €843,000 (€0) in total R\&D subsidies, and expends €6 million $(€ 710,000)$ on private $\mathrm{R} \& \mathrm{D}$.

\section{(A3) Instrument for Defense R\&D Subsidies.}

Our IV is predicted defense R\&D. The exact form of the IV depends on the dataset and level of aggregation.

\section{OECD data}

The endogenous variable is $S_{i k t}$, government funded R\&D in industry $i$ in country $k$ at time $t$. The IV for industry $i$ in country $k$ at time $t$ is defined as

$$
D R_{i k t}^{I V}=\operatorname{share}_{i k(t-1)}^{l} \cdot \widetilde{d e f_{k t}}
$$

where $\widetilde{d e f_{k t}}$ is country $k$ 's total defense R\&D spending in year $t^{31}$ and $\operatorname{share} e_{i k(t-1)}^{l}$ is a weighted average of one-year lagged government defense R\&D in industry $i$ as a share of all the government defense R\&D in the United States and France, where weights are country-industry-time specific and determined by the similarity of country k's patent technology class distribution to the United States relative to France.

For example, for a country $k$ like Japan our implementation of equation (A1) is:

$$
D R_{i k t}^{I V}=\left(\operatorname{share}_{i k(t-1)}^{U S} \cdot \text { weight }_{k}+\operatorname{share}_{i k(t-1)}^{F R} \cdot\left(1-\text { weight }_{k}\right)\right) \cdot \operatorname{DefGBAORD}_{k t}
$$

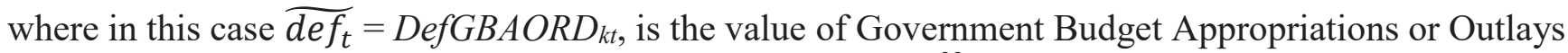
for defense related R\&D by country-year from OECD MSTI ${ }^{32}$ Note that we are not using the industry specific values of (for example) Japanese defense R\&D subsidies in equation (A2), but rather the Japanese economy-wide expenditure, which reduces the risk that the cross-industry allocation in Japan could be endogenous to current industry-year shock in Japan.

The industry variation comes from the first term, a weight that varies by industry, country and year, and that is itself a weighted average of the industry shares of defense spending for the two countries for which we can observe it: France and the US.

To construct the weights weight $_{k}$ for each country $k$, we start by measuring the similarity of country $k$ and the US or France, respectively, in terms of the distribution of patents across technology classes (which we have for the year 2005 for all countries from OECD from the database "Patents by

\footnotetext{
${ }^{31}$ Notice that this includes not only defense related R\&D subsidies spent by businesses, but also spend by sectors including e.g., universities (called "government budget appropriations or outlays on R\&D" or GBAORD by the OECD). We do not have aggregate numbers for the business sector only component for all OECD countries (only for France). In Table 3 we conduct robustness tests where we control for non-business R\&D to make sure our affects are not being driven by defense R\&D carried out in government labs or universities.

${ }^{32}$ Ideally, we would like to know the part of business enterprise R\&D that was solely related to defense spending and then to break this down into the government and privately financed components, but this is unavailable. In the time series, however, it is likely that increases in DefGBAORDkt are strongly associated with increases the part of public R\&D that goes to defense. Our first stages regressions confirm that this relationship is strong in the data. Further, for the US and for France we have a more detailed breakdown and we confirm that the correlation is 0.73 (US) and 0.88 (France).
} 
main technology and by International Patent Classification (IPC)"). More specifically, we calculate the distance between the patent technology classes of one country and the US in the following way:

$$
\operatorname{dist}_{k}^{U S}=\sqrt{\sum_{p}\left(\text { techs }_{p, k}-\text { techs }_{p, U S}\right)^{2}}
$$

where $\operatorname{techs}_{p, k}$ indicates the share of patents in technology class $p$ in country $k$ (and we define $\operatorname{dist}_{k}^{F R}$ in an analogous way).

The weight weight $_{k}$, that determines how much weight country k gives to the industry share of the US, is then defined as

$$
\text { weight }_{k}=1-\frac{\operatorname{dist}_{k}^{U S}}{\operatorname{dist}_{k}^{F R}+\operatorname{dist}_{k}^{U S}}=\frac{\operatorname{dist}_{k}^{F R}}{\operatorname{dist}_{k}^{F R}+\operatorname{dist}_{k}^{U S}}
$$

The intuition is the following: The weight that country $k$ puts on the US is larger, the smaller the distance between country $k$ and the US, relative to the distance between country $k$ and France. According to this definition, the US gets a weight of 1 for defense shares from the US (same for France), which raises endogeneity concerns for these countries. However, our results are robust to dropping the US and/or France.

Using a combination of the specific industry breakdowns of the US and France (instead of Japan's) should again mitigate concerns that the industry allocation of defense R\&D could be endogenous.

\section{French Firms}

Next, consider our firm-level instrument in France. In this case the instrument is defined as

$$
D R_{f, i 4, t}^{I V}=\operatorname{share~}_{i 4} \cdot \widetilde{d e f_{l 3, t}}
$$

The weight, share $_{i 4}$, share $_{i 4,(t-1)}$, is the share of public expenditure on business conducted defense R\&D in the firm's four-digit industry ("i4") as a share of the three-digit industry ("i3") that the fourdigit industry is located in (aggregated up from the firm level data) averaged over the entire sample period. Our preferred method uses a time invariant average because $\operatorname{share}_{i 4, t}$ can be noisy due to the changing year by year stratified random sampling. Further, we define $\widetilde{d e f_{l 3, t}}=d e f_{i 3, t-1}+\Delta \widetilde{d e f} f_{i 3, t}$ where $\Delta$ is the first difference operator and $\widetilde{d e} f_{i 3, t}=\operatorname{def}_{i 3, t}-d e f_{f, t}$ is three-digit public R\&D defense subsidies leaving out firm $f$ 's defense R\&D subsidies. Therefore $\widetilde{d e f_{l 3, t}}$ is close to the "leave-out mean. The reason for excluding def $f_{f, t}$ from the construction of the IV is that the endogenous variable $S_{f, t}$ is partly composed of $\operatorname{def}_{f, t}$ (the other component is the firm's non-defense related part of R\&D subsidies). Thus, including def $f, t$ in the IV would lead to a mechanical (and potentially endogenous) correlation between the endogenous variable we want to instrument and the instrument itself. ${ }^{33}$

\footnotetext{
${ }^{33}$ One could also have the same concern about DefGBAORD in equation (A2) in the OECD data. It would be desirable to remove industry-country specific defense R\&D subsidies from the construction of the IV. But, as noted below, we do not observe this for every country-industry-year cell in the OECD. However, nothing critical hinges on this. We can show in the French data, that failing to exclude the own industry defense subsidies only increases the precision of the results to a minor extent.
} 


\section{French Industries}

Finally, consider the French industry level analysis. When pooled in the OECD regressions we use equation (A2). However, when we implement the more disaggregated industry analysis of (say Table 4, Panel A) we can disaggregate the IV further. In particular the instrument is:

$$
D R_{i 3, t}^{I V}=\operatorname{share~}_{i 3} \cdot \widetilde{d e f_{l 2, t}}
$$

and everything is defined analogously to equation (A3) but at the industry level. So, share $e_{i 3}$, is the average share of public expenditure on defense R\&D in the firm's three-digit industry ("i3") as a share of the two-digit industry ("i2"). And $\widetilde{d e f_{l 2, t}}=d e f_{i 2,(t-1)}+\Delta d \widetilde{d e f}_{i 2, t}$ is the two-digit defense R\&D subsidies leaving out the three digit industry subsidies $\left(\widetilde{\operatorname{def}} 2_{i 3, t}=\operatorname{def}_{i 2, t}-\operatorname{def}_{f 3, t}\right)$.

\section{Other data details of the implementation of defense IV}

The instrument we use is:

$$
Z_{i t}=\ln \left(1+D R_{i t}^{I V}\right)
$$

We take logarithms as the R\&D series is very skewed and we add a dollar due to zeros (there are no true zeros in the OECD data, so this only affects the French data). We check that the arbitrary adding one did not matter in various ways, such as considering the non-logged version, etc.

Looking at the weight used in (A4) compared to (A2) (or (A3)), note that we could use the US share of industry instead of the French share. We did consider this, but in order to obtain a concordance between France and the US industry definitions we had to aggregate the industries even further, losing much of the industry granularity of the French data.

Note that a practical advantage of our construction of the IV in equation (A2) is that we do not have industry and time specific variation of public defense R\&D subsidies for all out countries in the OECD sample. This was a key motivation for looking at the French data where we can observe defense subsidies at every level from the firm upwards. However, it is also possible to calculate industry specific R\&D shares for the US.

In the US, we can observe data on individual defense contracts that are made publicly available because of procurement transparency rules. Draca (2013) analyses the millions of defense contracts from the early 1960s onwards and generously shared his data with us. His dataset combines historical military procurement data from the National Archives and Records Administration (NARA) with company accounts information from COMPUSTAT. NARA procurement data contains all prime military contracts awarded by the Department of Defense (DoD) between 1966 and 2003. Each year comprises around 250,000 different contracts awarded for the procurement of goods and services, with a minimum reporting threshold of 25,000 USD between 1984 and 2003 (the part of the dataset that we use). The data includes a four-digit product code known as the Federal Supply Code (FSC): we use only expenses with product code "R\&D" as our measure of defense related R\&D spending. Draca matched the name of the awardee with the COMPUSTAT database. The COMPUSTAT data include a four-digit SIC industry classification (SIC4) for each company. We aggregated the defense R\&D expenses by industry and match the SIC4 industry codes to the (more aggregate) industry classification used in the OECD datasets in order to get a distribution of R\&D defense spending across industries in the US. The US defense contracts data ends in 2003, so we assume the US weights remain the same for the last few years of the data. The timing of the data is such that it corresponds to the mid-year fiscal year (September) so that the data is partially lagged. 


\section{APPENDIX B: COMPARISON OF DIRECT PUBLIC SUBSIDIES COMPARED TO THE R\&D TAX CREDITS}

\section{Baseline Case}

To evaluate the magnitude of the impact of public subsidies we compare them to R\&D tax credit policies. In particular, we take the US and consider abolishing the federal R\&D tax credit and allocating all these funds to direct government R\&D grants.

The latest official estimated cost of the US federal R\&D tax credit was $\$ 11.3$ billion per annum (National Science Board, 2018). Tax advantages for R\&D (in particular, the Research and Experimentation tax credit) reduced the tax-adjusted user costs of R\&D capital by about 4\% in 2016 according to (OECD, 2019). ${ }^{34}$ Our estimates in column (6) of Table 3 Panel B find a (long-run) elasticity of R\&D with respect to its cost of about unity similar to that of Bloom, Griffith and Van Reenen (2002) and the survey by Becker (2015).

Using the most recent available data (2016), privately funded US R\&D was $\$ 356$ billion $^{35}$, so an elasticity of unity implies that fiscal incentives for R\&D increase actual R\&D by $\$ 14.2$ billion $\left(=356^{*} 0.04 * 1\right)$. If we abolished the tax credit system and allocated this $\$ 11.3$ billion to direct public R\&D spending, this would raise federally funded R\&D by $9.7 \%$ (this stood at $\$ 116.2$ billion in 2016 , so $11.3 / 116.2=0.097)$. Given our baseline estimates of a (crowd-in) elasticity between privately funded and publicly funded R\&D of 0.56 , this implies an increase in private R\&D of $5.4 \%$ or $\$ 19.4$ billion (= $356 * 0.56 * 0.097)$.

Total R\&D therefore increases by $\$ 30.7$ billion in the case of reallocating the R\&D tax credit: $\$ 11.3$ billion extra in public R\&D and $\$ 19.4$ billion from private $R \& D$.

The bottom line is that the same amount of public funds spent on the current R\&D tax credit system ( $\$ 11.3$ billion) raises private $\mathrm{R} \& \mathrm{D}$ by about twice as much if was allocated by the direct government grants considered in this paper compared to the current use (\$30.7 vs. $\$ 14.2$ billion). These numbers are similar orders of magnitude, but do suggest a better "bang for the buck" of direct governments grants than fiscal incentives (25 vs. 14). The experiments below suggest that this is a qualitatively robust conclusion.

\section{Robustness}

Years. The above calculation is for 2016, the last available year of confirmed data from the NSF. If we can use their more preliminary forecasts for 2018, the impact of direct public funding is roughly the same at $\$ 31.3$ billion (2018 prices), but the $\mathrm{R} \& \mathrm{D}$ tax credit looks better value at $\$ 20.2$ billion. This is

\footnotetext{
${ }^{34} \mathrm{https}$ ://stats.oecd.org/fileview2.aspx?IDFile=ebb21ac1-1802-4b57-9c74-68338a86a6cb. This is the modelled reduction for a "large profitable" firm. In the case of the US, it is similar for smaller firms.

${ }^{35}$ This is derived from Table 1 in National Science Foundation (2020). At time of writing 2016 are the actual numbers whereas 2017 and 2018 are forecasts.
} 
because (i) the tax subsidy has become more generous (a 5\% reduction instead of $4 \%$ ) and (ii) private R\&D has risen by more than public R\&D. Nevertheless, the qualitative statement that direct funding delivers a better "bang for the buck" still holds.

Quality of Public $R \& D$. We assume that the social value of public $R \& D$ is the same as private $R \& D$. One might argue that public R\&D is spent less efficiently than private $R \& D$. On the other hand, the general view is that public R\&D is targeted more on the high spillover areas - more basic, more risky, less market stealing, etc. so is likely to be more socially (although not privately) valuable. This would mean we are underestimating the advantage of public funding of R\&D.

Note that since we assume a dollar of $R \& D$ is the same regardless of source, we do not have to take a stand on the impact of R\&D on aggregate TFP, etc.

Elasticity of $R \& D$ with respect to its user cost. The elasticity of one is common in macro studies (and is what we estimate in the paper). However, we could use alternative estimates, and the efficacy of the tax credit scales with this. For example, if we used a value of two (as suggested by the micro study of Dechezlepretre et al, 2019), then the tax credit generates $\$ 28$ billion more $R \& D$, almost as much as direct funding. One might be concerned, however, that the micro estimates incorporate business stealing and miss the equilibrium R\&D price effects - this means that they overestimate the policy relevant elasticity. ${ }^{36}$ On the other hand, our OLS estimates in Panel A of Table 3 are as low as 0.62, suggesting that the tax credits only boost R\&D by $\$ 8.8$ billion. This suggests that direct governments grants are at least no worse than tax credits.

Level of the User Cost. We use the latest OECD estimates of the impact of tax credits. The OECD uses "Warda's B", which is the tax price element of the user cost (also used in our paper). To convert Warda's $B$ into a user cost we need to multiply it by the sum of the real interest rate plus depreciation $(r+d)$. However, a $1 \%$ fall in Warda's B holding interest rates and depreciation constant is the same as a $1 \%$ fall in the user cost, so this is a valid calculation.

The value of B in our paper (Table 3) is from Thomson (2012). This takes a value of $1.4 \%$ in 2006 instead of the OECD's 4\%. It is unclear why there is such a difference, but seems better to go with the most recent methods. Clearly, if we use the lower figure then the tax credit becomes even less valuable.

Administrative Costs. Tax credits have lower administrative costs than direct grants, but compared to the amounts given out, it is unlikely that these differences would make a material difference to the conclusion.

\footnotetext{
${ }^{36}$ Having said this, business-stealing effects are modest in the well-identified micro literature, which seeks to deal with them (Bloom, Schankerman and Van Reenen, 2013). In addition, estimates of the equilibrium price effects in our paper (industry level) or macro level appear quantitatively small.
} 


\section{APPENDIX C: Simulation of a US R\&D shock on R\&D and productivity, including spillovers}

Appendix Figure A3 describes the linkages between an R\&D shock in the US (calibrated to the $9 / 11$ events) and the way this reverberates throughout the domestic US economy in terms of changes to public and private sector $\mathrm{R} \& \mathrm{D}$ as well as the international economy. We estimated that, on net, such a shock increases US TFP growth by $2.6 \%$ and the following calculations explain how this was calculated.

9/11 shock in the US. Between 2001 and 2004 US defense R\&D spending (DefGBAORD) increased by $52 \%$, from $\$ 46 \mathrm{~b}$ to $\$ 70 \mathrm{~b}$. This represents an increase of US defense R\&D spending as a proportion of GDP from $0.45 \%$ to $0.60 \%$ : by 0.15 percentage points.

Effect on US public R\&D. Using the elasticity of public R\&D with respect to defense R\&D estimated in Table A4, column (3), the first stage of Table 3, column (3), the 9/11 shock generates a $4.8 \%$ increase in US public R\&D.

Effect on US private R\&D ("crowding in"). The increase in public R\&D leads to an increase of US private $R \& D$ by $2.5 \%$, using the elasticity of public $R \& D$ on private $R \& D$ as estimated in Table 3, column (3), panel B.

Effect on US total R\&D. From Table 1 we can see that in the United States the share of public $R \& D$ in total $R \& D$ is on average $15.5 \%$. The growth of US public R\&D and US private $R \& D$ therefore translates into a growth of US total R\&D of $2.9 \%$. Since total business conducted R\&D (BERD) as a proportion of GDP was $1.95 \%$ in the United States in 1997-2001, this increase is equivalent to an increase of BERD/GDP by 0.06 percentage points.

Effect on US TFP growth. Using Table 6, column (3), the increase of R\&D/GDP translates into an increase of the TFP growth rate by 0.005 percentage points. Since the US TFP growth rate in 2000 was $0.4 \%$, this represents an increase of around $1.5 \%$.

Alternatively, a simpler method is to take the number can be directly from the reduced form estimates of Table 6, column (4) which has the effect of defense R\&D on TFP growth. This produces an estimate of $3.2 \%$.

Taken together, this suggests that the increased in military R\&D on the scale of the $9 / 11$ shock increased TFP growth by about $1.5 \%$ to $3 \%$.

So far we have considered only the effect of the $9 / 11$ defense expenditure shock on the US. However, our regressions show that this shock also influences foreign countries. On one hand, there is a displacement effects, lowering private R\&D in foreign countries (Table A11). ${ }^{37}$ On the other hand, there are direct spillover effects, increasing TFP growth in foreign countries (Table A10). The spillover effects dominate in all our estimations, leading to a net positive increase of TFP growth in the foreign country.

Effect on foreign private R\&D (displacement effect). The increase in US total R\&D reduces foreign private R\&D by the elasticity on the international spillover pool (Table A11, column (3); using geography as distance measure) multiplied by the distance weight of the US to the foreign country. For example, the average geographic distance weight of the US to other countries is 0.02 ; which translates into reduced private R\&D on average of around $-0.02 \%(=2.9 \% *(-0.325) * 0.02)$.

Effect on foreign total R\&D. Assuming that public R\&D is unchanged in the foreign country, this reduction in private $R \& D$ is multiplied by the share of private $R \& D$ in total $R \& D(=1$ minus the share of public R\&D in total R\&D as given by Table 1; for the average country, the share of public R\&D in total $R \& D$ is $9.5 \%$ ) for the foreign country to yield the effect on foreign total $R \& D$, which yields a

\footnotetext{
${ }^{37}$ Table A11 is a simplified version of Table 5, which combines the international public and business R\&D into one international total R\&D spillover pool. This simplifies the calculations in this section.
} 
decrease in total R\&D by $0.017 \%$. Table A2 helps again to translate this percentage increase of foreign total R\&D into a percentage point increase of foreign total R\&D/GDP; for the average country we get a reduction by 0.0002 percentage points in terms of total R\&D/VA.

Effect on foreign TFP growth. As discussed above, there is both a displacement effect as well as a positive spillover effect. The displacement effect reduces foreign total $\mathrm{R} \& \mathrm{D}$ as shown above. Using Table A10, reduced foreign $R \& D /$ value added leads to reduced foreign TFP growth (given by the estimated coefficient on R\&D/value added in column (3) of panel A). For example, in the case of the average country, the TFP growth rate falls by 0.00001 percentage points. However, the increase of US total R\&D/VA by 0.06 percentage points (as shown above) has positive spillover effects, as given by the coefficient on the international spillover pool estimated in Table A10, panel A, column (3), again multiplied by the distance weight of the US with respect to the foreign country. In the case of the average country, this leads to an increase in the TFP growth rate by 0.0002 percentage points. Since the positive spillover effect dominates the displacement effect, this is also roughly the same as the net increase in the TFP growth rate; and equivalent to the TFP growth rate increasing by $0.028 \%$.

So in conclusion, a $9 / 11$ type shock raises TFP growth by $1.5 \%$ in the US and an average of $0.028 \%$ in the rest of the OECD. This shock, which raised US defense R\&D spending by $52 \%$, would result in an additional $\$ 37$ billion (nominal, PPP adjusted) if it happened again in 2013. According to our estimated increase in the US TFP growth rate, this then leads to an additional \$0.9bn GDP per annum in the US, and an additional \$0.2bn GDP per annum in the rest of the world. 
FIGURE 1: DEFENSE R\&D AS PERCENT OF GDP IN THE US, GERMANY, JAPAN AND FRANCE
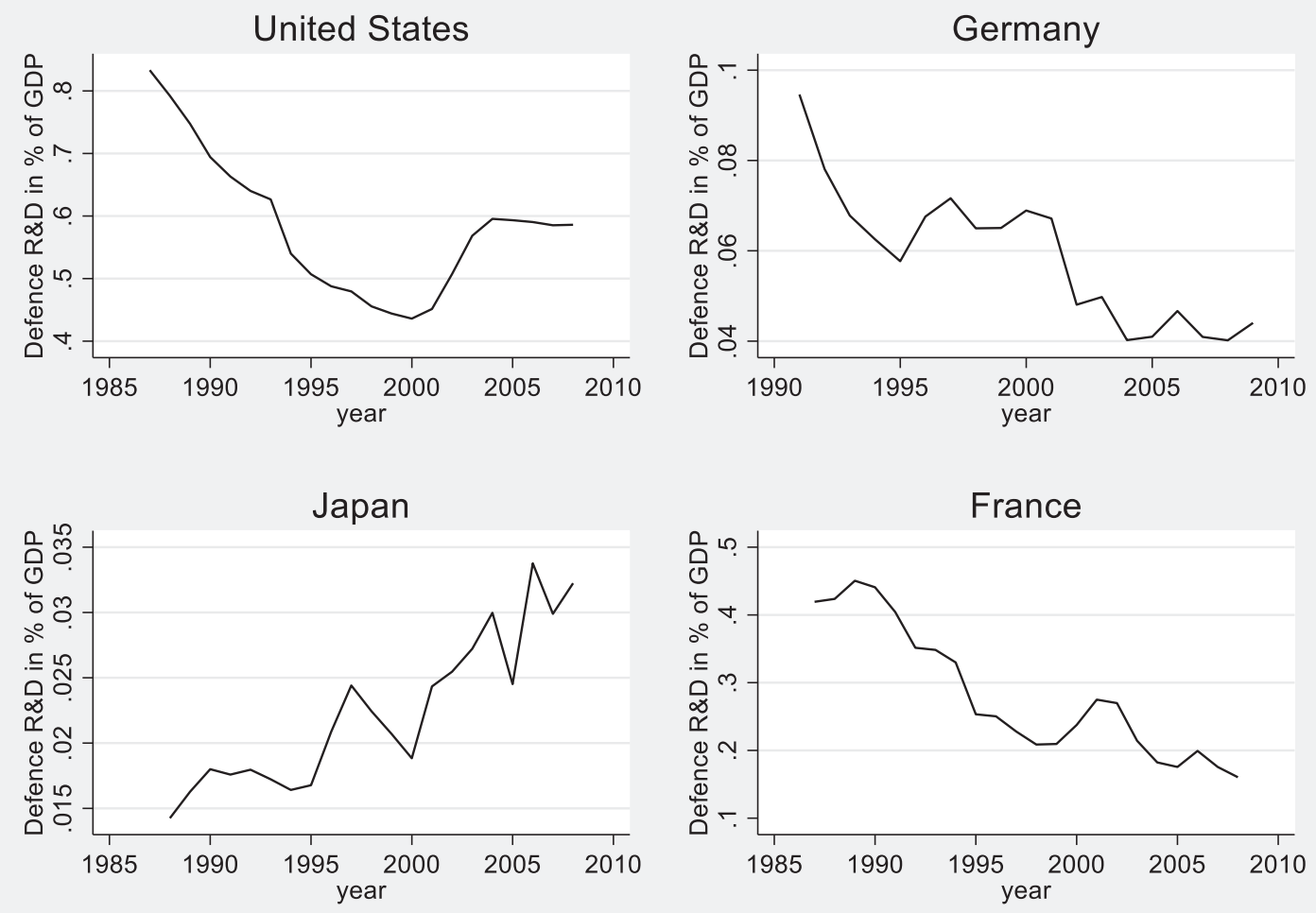

Notes: This figure shows the defense related, government funded total R\&D as a share of GDP. The defense R\&D in this figure refers to "all public R\&D" which includes all government budget appropriations or outlays of total R\&D, i.e. not just the government-funded part of business conducted R\&D, but also the government funded part of R\&D conducted outside of enterprises 
FIGURE 2: PUBLIC R\&D AND TOTAL DEFENSE R\&D - BY COUNTRY
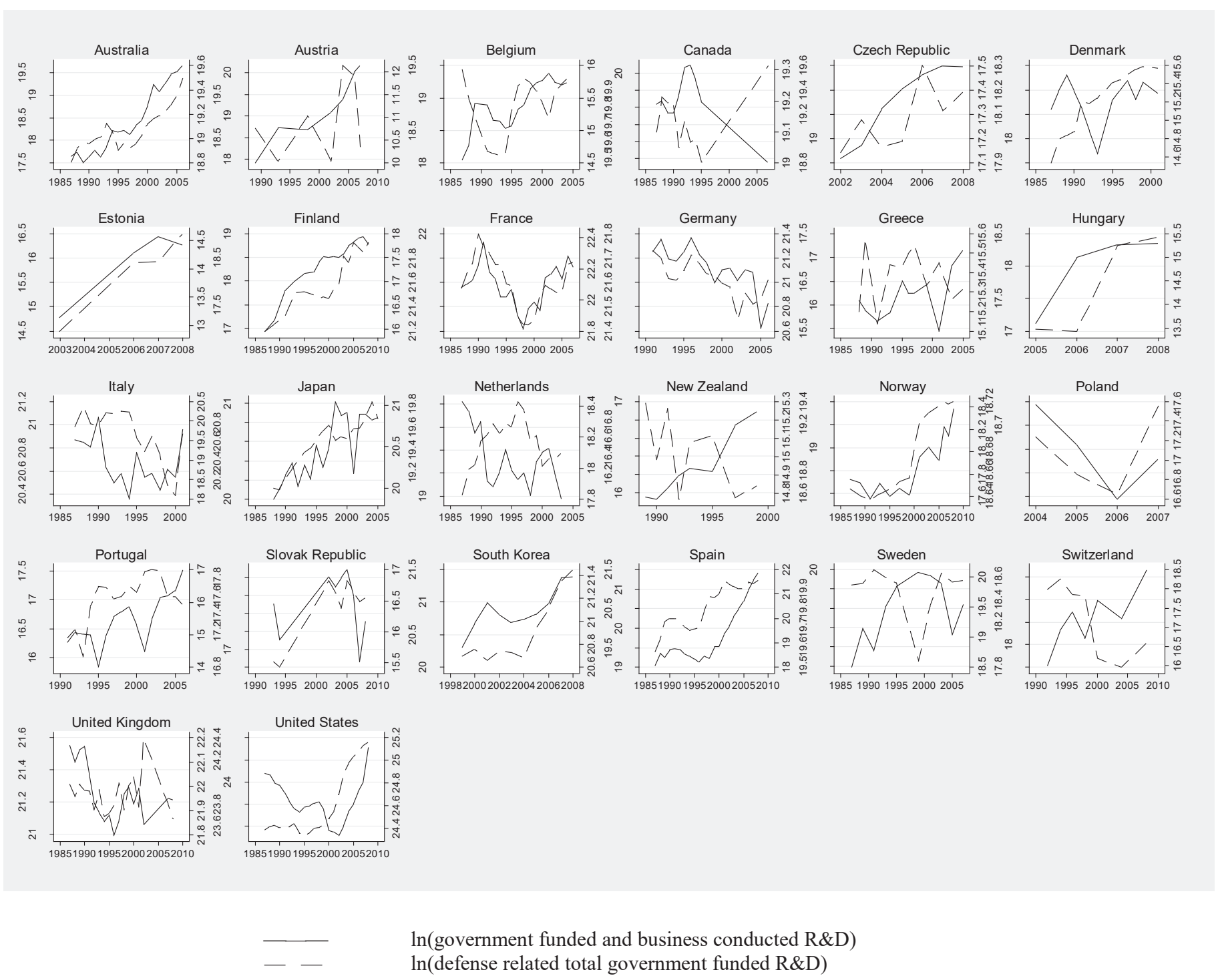

Notes: Solid line is the log of the government funded and business conducted BERD, which is scaled on the left axis. The dashed line is the log of government funded total defense R\&D (which includes all government budget appropriations or outlays of total R\&D, i.e. not just the government funded part of business conducted R\&D, but also the government funded part of R\&D conducted outside of enterprises), which is scaled on the right axis. 


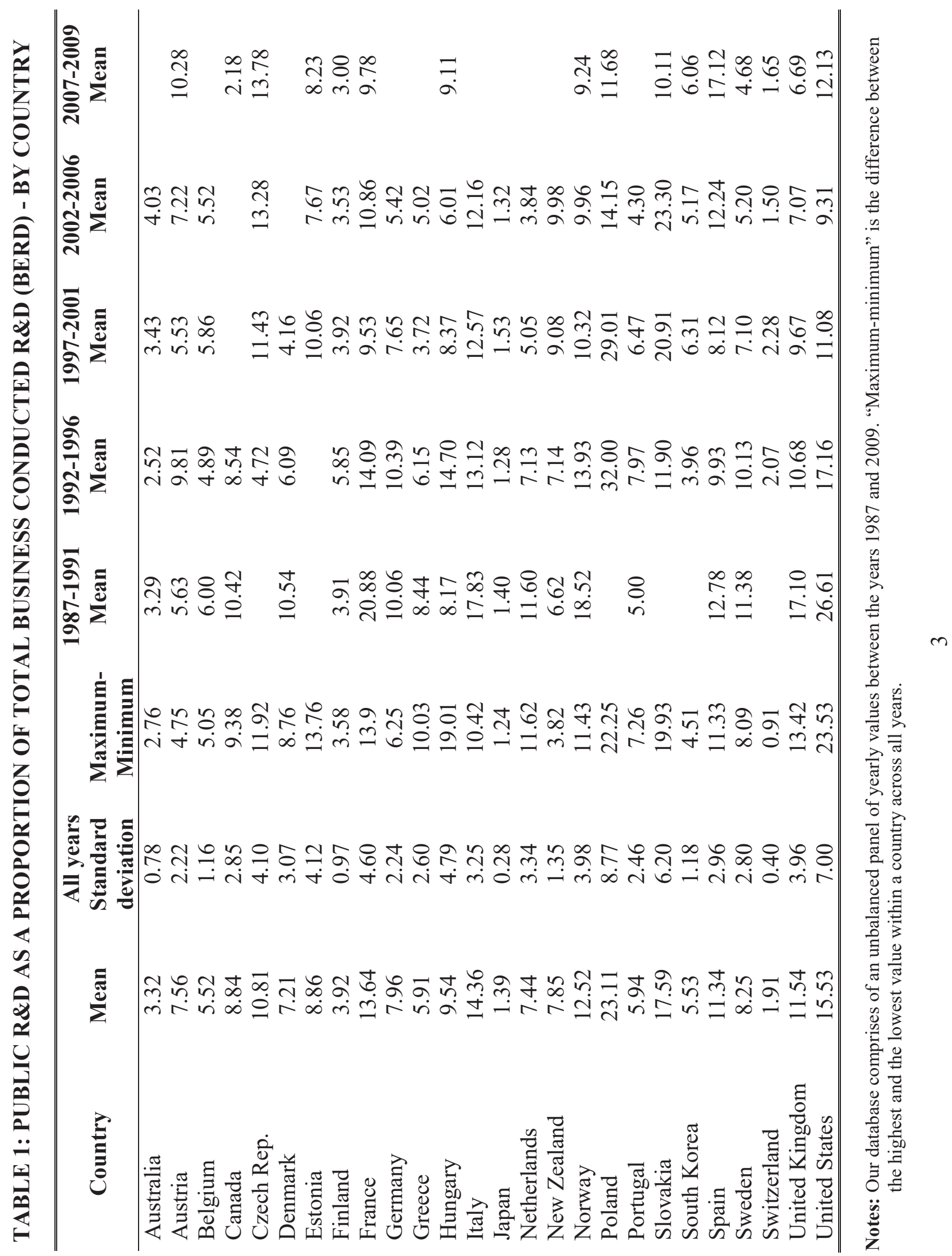


TABLE 2: DEFENSE SHARE OF TOTAL PUBLIC R\&D

\begin{tabular}{|c|c|c|c|c|c|c|c|}
\hline & $\begin{array}{c}\text { All } \\
\text { years }\end{array}$ & All years & $\begin{array}{l}1987- \\
1991\end{array}$ & $\begin{array}{l}1992- \\
1996\end{array}$ & $\begin{array}{l}1997- \\
2001\end{array}$ & $\begin{array}{l}2002- \\
2006\end{array}$ & $\begin{array}{l}2007- \\
2009\end{array}$ \\
\hline Country & Mean & $\begin{array}{l}\text { Standard } \\
\text { deviation }\end{array}$ & Mean & Mean & Mean & Mean & Mean \\
\hline Australia & 8.09 & 1.87 & 11.18 & 8.40 & 6.70 & 6.86 & 7.34 \\
\hline Austria & 0.01 & 0.01 & 0.01 & 0.01 & 0.01 & 0.01 & 0.00 \\
\hline Belgium & 0.38 & 0.20 & 0.57 & 0.31 & 0.40 & 0.31 & 0.24 \\
\hline Canada & 5.08 & 1.32 & 6.86 & 4.88 & 5.08 & 3.86 & 3.24 \\
\hline Czech Rep. & 2.70 & 0.44 & & & & 3.02 & 2.33 \\
\hline Denmark & 0.60 & 0.21 & 0.44 & 0.61 & 0.53 & 0.88 & 0.55 \\
\hline Estonia & 0.96 & 0.55 & & & & 0.92 & 1.04 \\
\hline Finland & 1.97 & 0.58 & 1.54 & 1.97 & 1.43 & 2.56 & 2.32 \\
\hline France & 28.98 & 6.19 & 37.26 & 32.36 & 23.10 & 23.37 & 28.56 \\
\hline Germany & 8.47 & 2.58 & 12.46 & 9.22 & 8.36 & 6.01 & 5.92 \\
\hline Greece & 1.21 & 0.60 & 1.91 & 1.54 & 0.92 & 0.58 & 0.55 \\
\hline Hungary & 0.38 & 0.25 & & & & 0.10 & 0.56 \\
\hline Italy & 4.47 & 2.83 & 7.65 & 6.45 & 2.62 & 3.29 & 2.16 \\
\hline Japan & 5.03 & 0.74 & 5.27 & 6.01 & 4.74 & 4.57 & 4.44 \\
\hline Netherlands & 2.43 & 0.61 & 2.81 & 3.20 & 2.33 & 1.90 & 1.86 \\
\hline New & 0.91 & 0.41 & 1.50 & 1.07 & 0.73 & 0.95 & 0.00 \\
\hline \multicolumn{8}{|l|}{ Zealand } \\
\hline Norway & 6.15 & 1.30 & 7.77 & 5.64 & 5.77 & 6.55 & 4.82 \\
\hline Poland & 1.91 & 0.85 & & & & 1.42 & 2.64 \\
\hline Portugal & 0.93 & 0.81 & 0.14 & 1.45 & 1.52 & 1.18 & 0.27 \\
\hline Slovakia & 5.65 & 2.06 & & 3.58 & 6.65 & 7.40 & 4.96 \\
\hline South Korea & 16.59 & 2.69 & & & 19.59 & 14.52 & 17.22 \\
\hline Spain & 17.63 & 7.83 & 15.19 & 11.79 & 27.63 & 20.41 & 10.11 \\
\hline Sweden & 18.08 & 6.28 & 25.11 & 21.69 & 10.27 & 18.65 & 12.41 \\
\hline Switzerland & 4.10 & 3.92 & 10.17 & 4.84 & 2.29 & 0.50 & 0.59 \\
\hline $\begin{array}{l}\text { United } \\
\text { Kingdom }\end{array}$ & 35.00 & 8.16 & 44.27 & 39.08 & 36.10 & 28.97 & 20.93 \\
\hline $\begin{array}{l}\text { United } \\
\text { States }\end{array}$ & 57.20 & 4.98 & 64.84 & 56.34 & 52.94 & 55.50 & 55.83 \\
\hline
\end{tabular}

Note: Our database comprises of an unbalanced panel of yearly values between the years 1987 and 2009. The defense share of public R\&D in this table refers to "all public R\&D" which includes all government budget appropriations or outlays of total R\&D, i.e. not just the government funded part of business conducted R\&D, but also the government funded part of R\&D conducted outside of enterprises; while public defense R\&D is the defense related part of “all public R\&D”. 
TABLE 3: EFFECT OF PUBLICLY FUNDED R\&D ON PRIVATELY FUNDED R\&D - OECD DATA

\begin{tabular}{|c|c|c|c|c|c|c|}
\hline \multicolumn{7}{|c|}{ Dependent variable: $\ln$ (Privately funded business R\&D) } \\
\hline Panel A: OLS & & & & & & \\
\hline $\ln (\text { Public } R \& D)_{t-1}$ & $\begin{array}{c}0.128^{* *} \\
(0.028)\end{array}$ & $\begin{array}{c}0.147^{* *} \\
(0.027)\end{array}$ & $\begin{array}{c}0.143^{* *} \\
(0.027)\end{array}$ & $\begin{array}{c}0.144^{* *} \\
(0.028)\end{array}$ & $\begin{array}{c}0.144^{* *} \\
(0.028)\end{array}$ & $\begin{array}{c}0.145^{* *} \\
(0.028)\end{array}$ \\
\hline$R \& D$ tax credit $_{t-1}$ & & & & $\begin{array}{c}0.641 * * \\
(0.295)\end{array}$ & $\begin{array}{c}0.725^{* *} \\
(0.300)\end{array}$ & $\begin{array}{l}0.790 * * \\
(0.307)\end{array}$ \\
\hline $\ln$ (Non-bus. public & & & & & -0.328 & -0.313 \\
\hline $\mathrm{R} \& \mathrm{D})_{\mathrm{t}-1}$ & & & & & $(0.246)$ & $(0.243)$ \\
\hline (Corp. tax & & & & & & -3.305 \\
\hline revenue/GDP) $)_{\mathrm{t}-1}$ & & & & & & $(3.006)$ \\
\hline $\ln (\text { output })_{\mathrm{t}-1}$ & & & $\begin{array}{c}0.691 * * \\
(0.171)\end{array}$ & $\begin{array}{c}0.700^{* *} \\
(0.170)\end{array}$ & $\begin{array}{c}0.630^{* *} \\
(0.184)\end{array}$ & $\begin{array}{l}0.616^{* *} \\
(0.178)\end{array}$ \\
\hline $\ln (\mathrm{GDP})_{\mathrm{t}-1}$ & & & $\begin{array}{l}-0.184 \\
(0.458)\end{array}$ & $\begin{array}{l}-0.201 \\
(0.457)\end{array}$ & $\begin{array}{l}-0.101 \\
(0.484)\end{array}$ & $\begin{array}{l}-0.080 \\
(0.483)\end{array}$ \\
\hline Panel B: IV & & & & & & \\
\hline $\ln (\text { Public } R \& D)_{t-1}$ & $\begin{array}{c}0.561 * * \\
(0.140)\end{array}$ & $\begin{array}{l}0.492 * * \\
(0.199)\end{array}$ & $\begin{array}{l}0.518^{* *} \\
(0.204)\end{array}$ & $\begin{array}{l}0.476^{* *} \\
(0.190)\end{array}$ & $\begin{array}{l}0.508^{* *} \\
(0.203)\end{array}$ & $\begin{array}{l}0.477 * * \\
(0.196)\end{array}$ \\
\hline$R \& D$ tax credit $_{t-1}$ & & & & $\begin{array}{l}0.885^{*} \\
(0.470)\end{array}$ & $\begin{array}{l}0.993^{* *} \\
(0.496)\end{array}$ & $\begin{array}{l}1.092 * * \\
(0.485)\end{array}$ \\
\hline $\ln$ (Non-bus. public & & & & & -0.334 & -0.305 \\
\hline $\mathrm{R} \& D)_{\mathrm{t}-1}$ & & & & & $(0.237)$ & $(0.230)$ \\
\hline $\begin{array}{l}(\text { Corp. tax } \\
\text { revenue/GDP })_{\mathrm{t}-1}\end{array}$ & & & & & & $\begin{array}{l}-6.312^{*} \\
(3.406)\end{array}$ \\
\hline $\ln (\text { output })_{\mathrm{t}-1}$ & & & $\begin{array}{c}0.412 \\
(0.268)\end{array}$ & $\begin{array}{l}0.458^{*} \\
(0.255)\end{array}$ & $\begin{array}{c}0.364 \\
(0.285)\end{array}$ & $\begin{array}{c}0.360 \\
(0.276)\end{array}$ \\
\hline $\ln (\mathrm{GDP})_{\mathrm{t}-1}$ & & & $\begin{array}{c}0.092 \\
(0.534)\end{array}$ & $\begin{array}{c}0.036 \\
(0.521)\end{array}$ & $\begin{array}{c}0.161 \\
(0.567)\end{array}$ & $\begin{array}{c}0.177 \\
(0.551)\end{array}$ \\
\hline Observations & 5,026 & 4,459 & 4,459 & 4,459 & 4,459 & 4,459 \\
\hline $\begin{array}{l}\text { First stage F- } \\
\text { Statistic }\end{array}$ & 14.66 & 10.30 & 10.17 & 10.66 & 10.02 & 10.96 \\
\hline Anderson-Rubin & 9.630 & 5.316 & 5.918 & 5.503 & 5.516 & 5.345 \\
\hline Wald F-test p-value & 0.00208 & 0.0218 & 0.0156 & 0.0196 & 0.0195 & 0.0215 \\
\hline
\end{tabular}

Notes: Two-way clustered standard errors at the industry-country and country-year level. The dependent variable is private R\&D, i.e., R\&D conducted in the business sector (BERD) that is also financed by the private sector (i.e., excludes government financed R\&D). "Public R\&D" is government-financed R\&D performed by private firms. "R\&D tax credit" is Warda's BIndex from Thomson (2012) and the coefficient can be interpreted as the elasticity of R\&D with respect to its tax adjusted user cost (see Appendix B). "Non-business public R\&D" is government-financed R\&D performed not by the private sector, e.g. universities or other institutions. "Corporate tax revenue/GDP" is tax revenue from taxes on income, profits, and capital gains of corporates divided by GDP (from OECD). All columns include a full set of country*industry fixed effects and industry*year fixed effects, as well as linear country time trends. Models in Panel B use predicted government funded defense $\mathrm{R} \& \mathrm{D}$ as an instrument for government-financed R\&D (see text). "First stage F" is the Kleibergen-Paap rk Wald F-statistic. The Anderson-Rubin Wald F-test tests the null hypothesis of weak instruments. All regressions are weighted by the industrycountry pair's initial share of employment in total country employment. ** significant at $5 \%$ level, * significant at $10 \%$ level. 


\section{TABLE 4: EFFECT OF PUBLICLY-FUNDED R\&D ON PRIVATELY-FUNDED R\&D - FRENCH DATA}

$\begin{array}{llcl}(1) & (2) & (3) & (4) \\ \text { OLS } & \text { IV } & \text { OLS } & \text { IV }\end{array}$

Dependent variable: $\ln ($ Privately funded business R\&D)

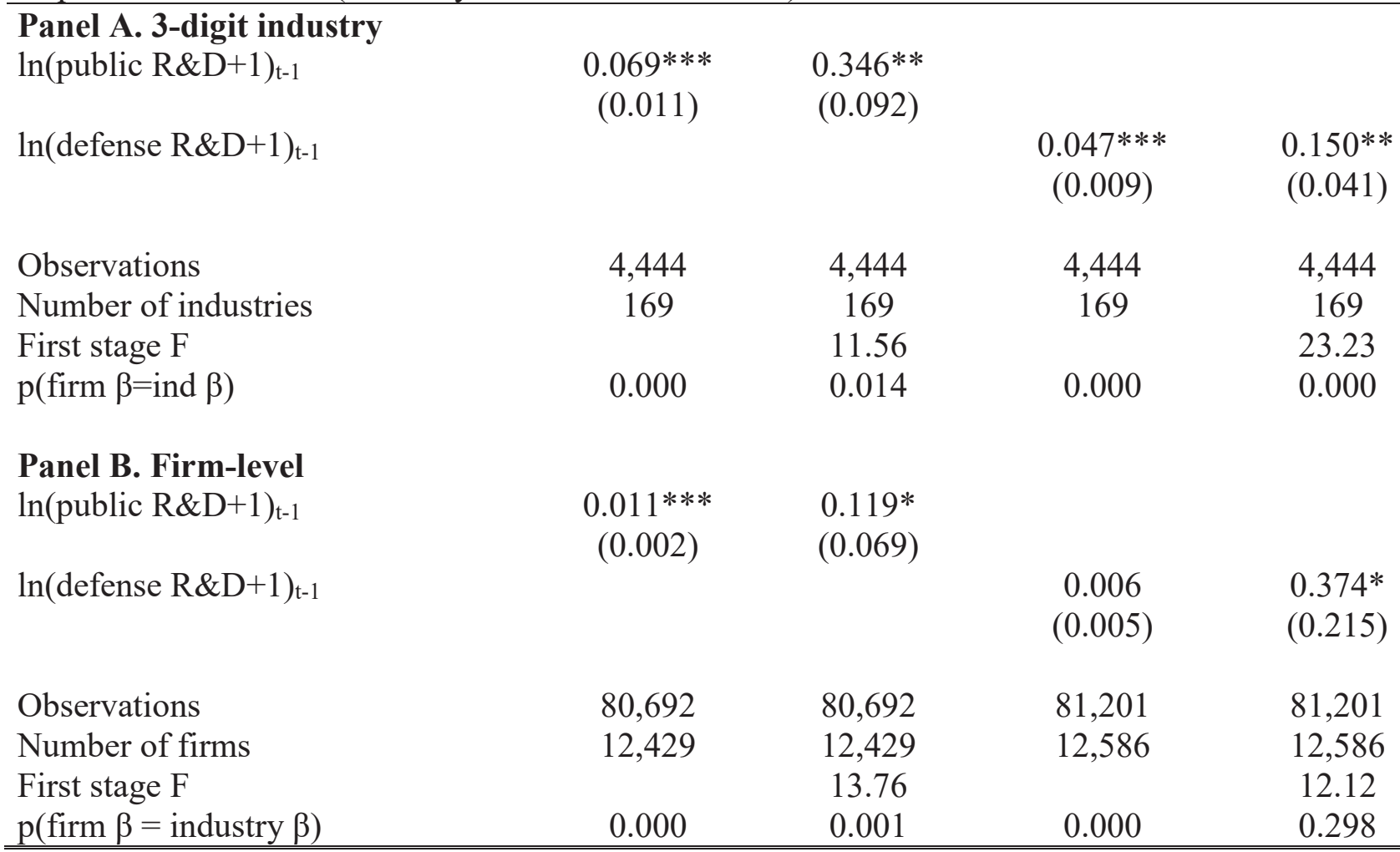

Notes: The dependent variable is private R\&D, i.e., R\&D conducted in the business sector (BERD) that is also financed by the private sector (i.e., excludes government financed R\&D). "Public R\&D" is government-financed R\&D performed by private firms. All columns include year fixed effects; Panel A (B) includes 3-digit industry (firm) fixed effects. All variables in Panel B are winsorized at the $0.5 \%$ tails. "First stage F" is the Kleibergen-Paap rk Wald F-statistic. We use predicted government funded defense R\&D as an instrument for government-financed R\&D (see text). Standard errors in Panel A (B) are clustered at the 2-digit (3-digit) industry level. ${ }^{* *}$ significant at $5 \%$ level, * significant at $10 \%$ level. "p(firm $\beta=$ ind $\left.\beta\right)$ " is a test of whether the coefficient in Panel A (industry level) is equal to that in Panel B (firm level). 


\section{TABLE 5: INTERNATIONAL SPILLOVERS - IV ESTIMATES - OECD DATA}

\begin{tabular}{|c|c|c|c|c|c|c|}
\hline $\begin{array}{l}\text { Method of } \\
\text { calculating } \\
\text { spillovers from } \\
\text { neighbors } \\
\text { Dependent variabl } \\
\end{array}$ & $\begin{array}{c}(1) \\
\text { Baseline }\end{array}$ & $\begin{array}{c}(2) \\
\text { Per-capita } \\
\text { GDP }\end{array}$ & $\begin{array}{c}(3) \\
\text { Geo- } \\
\text { graphy }\end{array}$ & $\begin{array}{c}(4) \\
\text { Skill } \\
\text { Intensity }\end{array}$ & $\begin{array}{c}(5) \\
\text { Tech- } \\
\text { nology }\end{array}$ & $\begin{array}{c}\text { (6) } \\
\text { R\&D } \\
\text { Intensity }\end{array}$ \\
\hline \multicolumn{7}{|c|}{$\begin{array}{l}\text { Dependent variable: } \ln (\text { Privately funded business R\&D) } \\
\text { Panel A. Effect of Public R\&D }\end{array}$} \\
\hline $\ln ($ public R\&D)t-1 & $\begin{array}{c}0.561 * * \\
(0.140)\end{array}$ & $\begin{array}{l}0.633^{* *} \\
(0.147)\end{array}$ & $\begin{array}{c}0.578^{* *} \\
(0.150)\end{array}$ & $\begin{array}{c}0.562 * * \\
(0.187)\end{array}$ & $\begin{array}{c}0.693 * * \\
(0.222)\end{array}$ & $\begin{array}{l}0.629 * * \\
(0.165)\end{array}$ \\
\hline $\begin{array}{l}\ln (\text { int. public } \\
\text { R\&D)t-1 }\end{array}$ & & $\begin{array}{l}0.151^{* *} \\
(0.053)\end{array}$ & $\begin{array}{l}0.408^{* *} \\
(0.136)\end{array}$ & $\begin{array}{c}0.074 \\
(0.076)\end{array}$ & $\begin{array}{l}0.909^{* *} \\
(0.211)\end{array}$ & $\begin{array}{l}0.192 * * \\
(0.088)\end{array}$ \\
\hline Observations & 5,026 & 5,022 & 5,022 & 4,582 & 5,022 & 5,022 \\
\hline First stage $\mathrm{F}$ & 14.66 & 11.08 & 11.97 & 9.369 & 9.141 & 11.12 \\
\hline $\begin{array}{l}\text { Panel B. Effect of } \\
\ln (\text { public R\&D)t-1 }\end{array}$ & $\begin{array}{c}\text { iness R\&I } \\
0.561 * * \\
(0.140)\end{array}$ & $\begin{array}{c}0.566^{* *} \\
(0.159)\end{array}$ & $\begin{array}{c}0.575^{* *} \\
(0.144)\end{array}$ & $\begin{array}{c}0.566^{* *} \\
(0.174)\end{array}$ & $\begin{array}{c}0.541^{* *} \\
(0.165)\end{array}$ & $\begin{array}{c}0.476^{* *} \\
(0.144)\end{array}$ \\
\hline $\begin{array}{l}\ln \text { (int. business } \\
\text { R\&D)t-1 }\end{array}$ & & $\begin{array}{c}0.007 \\
(0.045) \\
\end{array}$ & $\begin{array}{l}-0.186 \\
(0.121) \\
\end{array}$ & $\begin{array}{l}-0.057 \\
(0.068) \\
\end{array}$ & $\begin{array}{c}-0.633 * * \\
(0.228)\end{array}$ & $\begin{array}{c}-0.269 * * \\
(0.103)\end{array}$ \\
\hline $\begin{array}{l}\text { Observations } \\
\text { First stage F }\end{array}$ & $\begin{array}{l}5,026 \\
14.66 \\
\end{array}$ & $\begin{array}{l}5,022 \\
13.54 \\
\end{array}$ & $\begin{array}{l}5,022 \\
13.77 \\
\end{array}$ & $\begin{array}{l}4,582 \\
10.96 \\
\end{array}$ & $\begin{array}{l}5,022 \\
14.19 \\
\end{array}$ & $\begin{array}{l}5,022 \\
13.48 \\
\end{array}$ \\
\hline \multicolumn{7}{|c|}{ Panel C. Effects of Public and Business R\&D } \\
\hline $\begin{array}{l}\ln (\text { public R\&D)t-1 } \\
\ln \text { (int. public } \\
\text { R\&D)t-1 } \\
\ln \text { (int. business } \\
\text { R\&D)t-1 }\end{array}$ & $\begin{array}{c}0.561^{* *} \\
(0.140)\end{array}$ & $\begin{array}{c}0.554 * * \\
(0.137) \\
0.249 * * \\
(0.060) \\
-0.167 * * \\
(0.058) \\
\end{array}$ & $\begin{array}{c}0.620 * * \\
(0.157) \\
0.569 * * \\
(0.170) \\
-0.431 * * \\
(0.151) \\
\end{array}$ & $\begin{array}{c}0.586^{* *} \\
(0.182) \\
0.123 \\
(0.094) \\
-0.135 \\
(0.091) \\
\end{array}$ & $\begin{array}{c}0.689^{* *} \\
(0.239) \\
1.086^{* *} \\
(0.304) \\
-0.959^{* *} \\
(0.253) \\
\end{array}$ & $\begin{array}{c}0.524 * * \\
(0.163) \\
0.300 * * \\
(0.094) \\
-0.462 * * \\
(0.113) \\
\end{array}$ \\
\hline $\begin{array}{l}\text { Observations } \\
\text { First stage F }\end{array}$ & $\begin{array}{l}5,026 \\
14.66\end{array}$ & $\begin{array}{l}5,022 \\
12.73\end{array}$ & $\begin{array}{l}5,022 \\
11.92\end{array}$ & $\begin{array}{l}4,582 \\
9.578\end{array}$ & $\begin{array}{l}5,022 \\
9.182\end{array}$ & $\begin{array}{l}5,022 \\
11.08\end{array}$ \\
\hline
\end{tabular}

Notes: Each colum in each panel presents a separate regression. Two-way clustered standard errors at the industry-country and country-year level. All columns include a full set of country*industry fixed effects and industry*year fixed effects, as well as linear country trends. All regressions are weighted by the industry-country pair's initial share of employment in total country employment. The dependent variable is private R\&D. Public R\&D is government-financed R\&D performed by private firms. "Int. public R\&D" is the weighted average of other countries' public R\&D in the same industry and year, where each column uses different weights. Weights $\omega_{k l}$ are a "distance" measure between country $k$ and country $l$ measured by: (2) GDP per capita. $\omega_{k l}=1 / \mid$ GDPcap $_{k}-$ GDPcap $l$; (3) Geographic distance. $\omega_{k l}=1 /$ dist $_{k l}$ where geographic distance is measured in kilometers between capital cities; (4) Skill intensity. $\omega_{k l}=1 / \mid$ tert $_{k}-$ tert $_{l} \mid$ with tert $_{l}$ being the share of population with tertiary education in country $l ;(5)$ Patent similarity. $\omega_{k l}=\sqrt{\sum_{i}\left(p t_{i k}-\text { pat }_{i l}\right)^{2}}$, pat $_{i k}$ and pat $_{i l}$ are patent share of a specific technology class $I$ (out of 15 patent technology classes) in country $k$ or $l$ (of total patents in that country); (6) R\&D intensity. $\omega_{k l}=$ $1 /\left|\frac{\text { Total } R \& D_{k}}{G D P_{k}}-\frac{\text { Total } R \& D_{l}}{G D P_{l}}\right| . * *$ significant at $5 \%$ level, * significant at $10 \%$ level. 
TABLE 6: EFFECT OF R\&D GROWTH ON TFP GROWTH

\begin{tabular}{|c|c|c|c|c|c|c|}
\hline & $\begin{array}{l}(1) \\
\text { OLS }\end{array}$ & $\begin{array}{c}(2) \\
\text { OLS } \\
\text { Annual }\end{array}$ & $\begin{array}{c}\text { (3) } \\
\text { IV } \\
\text { P growth }\end{array}$ & $\begin{array}{c}\text { (4) } \\
\text { Reduced } \\
\text { Form }\end{array}$ & $\begin{array}{c}\text { (5) } \\
\text { OLS } \\
\text { Annual labor pr }\end{array}$ & ctivity growth \\
\hline $\begin{array}{l}\text { (Total R\&D/value } \\
\text { added) })_{\mathrm{t}-1} \\
\text { (Predicted Defense } \\
\text { R\&D/value added) } \mathrm{t}_{\mathrm{t}-1} \\
\text { (Total } \mathrm{R} \& \mathrm{D} / \\
\text { sales) } \mathrm{t}-1\end{array}$ & $\begin{array}{l}0.095^{* *} \\
(0.040)\end{array}$ & $\begin{array}{c}0.098^{* *} \\
(0.041)\end{array}$ & $\begin{array}{c}0.097 * * \\
(0.031)\end{array}$ & $\begin{array}{c}0.083^{* *} \\
(0.030)\end{array}$ & $\begin{array}{c}0.026^{* *} \\
(0.004)\end{array}$ & $\begin{array}{c}0.040^{* *} \\
(0.004)\end{array}$ \\
\hline $\begin{array}{l}\text { Observations } \\
\text { Dataset } \\
\text { First stage F }\end{array}$ & $\begin{array}{c}6,102 \\
\text { OECD }\end{array}$ & $\begin{array}{l}6,102 \\
\text { OECD }\end{array}$ & $\begin{array}{c}6,102 \\
\text { OECD } \\
14.42\end{array}$ & $\begin{array}{c}6,102 \\
\text { OECD }\end{array}$ & $\begin{array}{l}\text { 4,404 } \\
\text { French Industries }\end{array}$ & $\begin{array}{c}82,743 \\
\text { French Firms }\end{array}$ \\
\hline Country FE & NO & YES & YES & YES & N/A & N/A \\
\hline
\end{tabular}

Notes: Columns (1)-(4) are OECD data and (5)-(8) are French data. Total R\&D is the sum of private R\&D, public R\&D and R\&D from any other source. Columns (1) through (4) use two-way clustered standard errors at the industry*country and country*year level, and are weighted with weights equal to the industry-country pair's initial share of employment in total country employment. Columns (5) through (8) use clustered standard errors at the 3-digit industry. All regressions include a full set of year fixed effects. Column (3) presents IV estimates using (defense R\&D)/value added as an instrument for R\&D/value added. Column (4) presents the reduced form estimate for column (3). ** significant at 5\% level, * significant at $10 \%$ level. 


\section{APPENDIX FIGURE A1: PUBLIC R\&D AND PREDICTED DEFENSE R\&D - BY INDUSTRY}
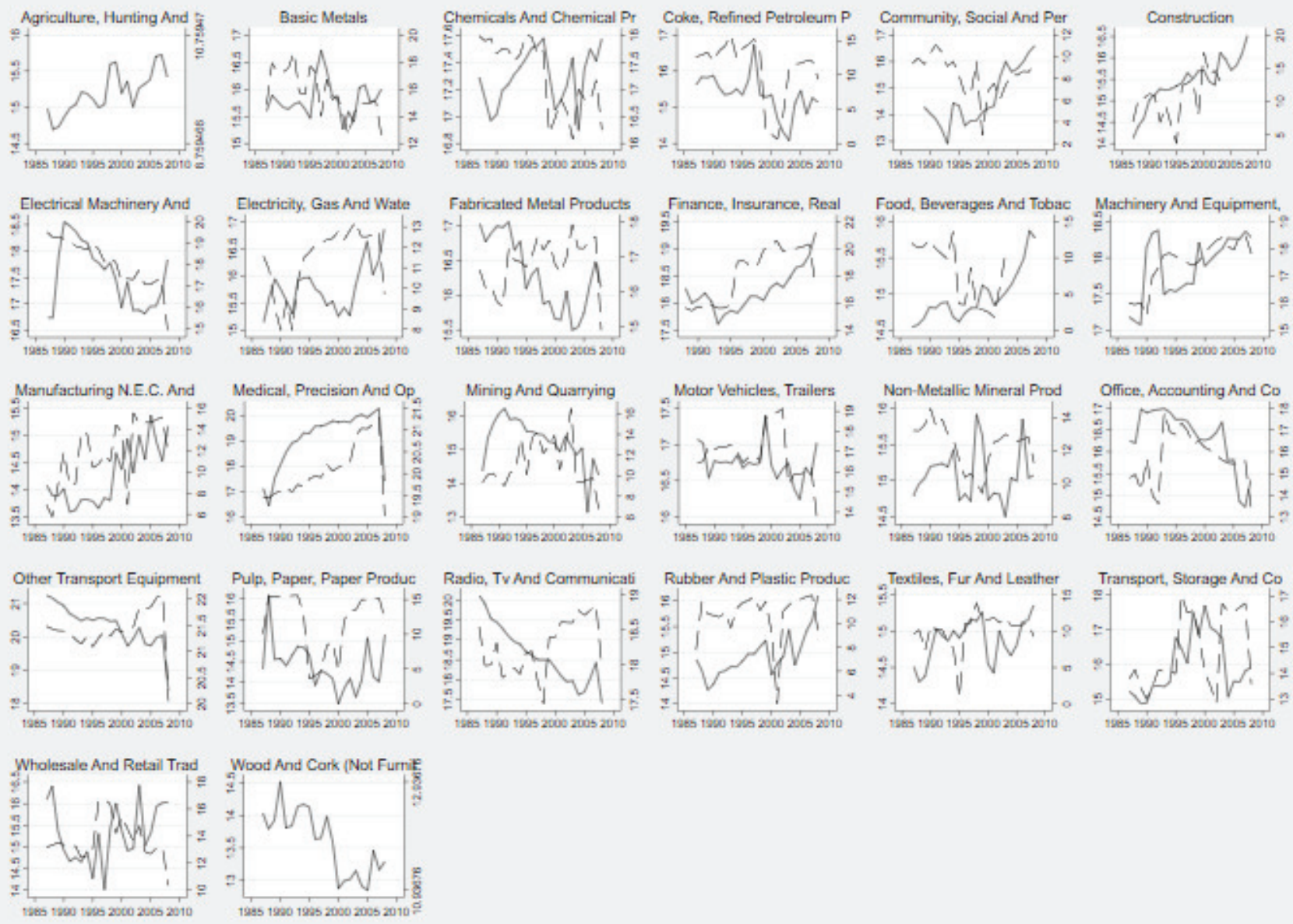

$\ln$ (government funded and business conducted R\&D)

- $\ln$ (predicted defense related government funded R\&D)

Notes: The solid line is the log of the government funded and business conducted BERD, which is scaled on the left axis. The dashed line is the log of predicted defense $R \& D$, our instrumental variable as explained in the text, which is scaled on the right axis. These are averages across all countries in our data set. Agriculture, hunting and forestry has zero predicted defense R\&D in all years. Wood and cork has zero predicted defense R\&D in all years but one. 


\section{APPENDIX FIGURE A2: IMPULSE RESPONSE FUNCTIONS TO VAR MODELS WITH CHANGES IN PUBLIC R\&D AND INDUSTRY OUTPUT}

\section{Panel A. Response of changes in public R\&D subsidies to lagged changes in industry output}

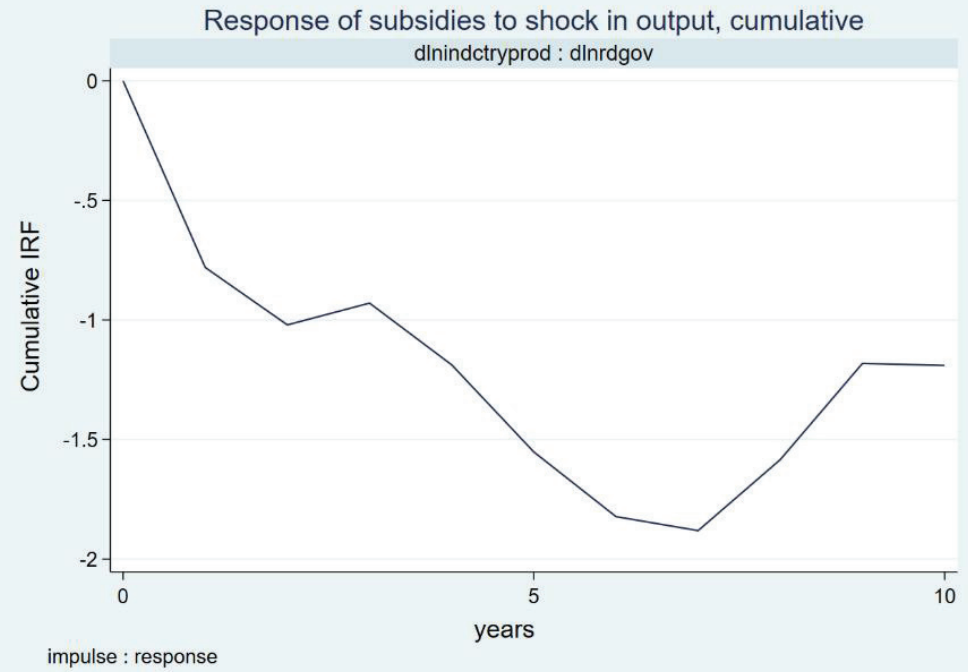

Panel B. Response of changes in industry output to lagged changes in public R\&D subsidies

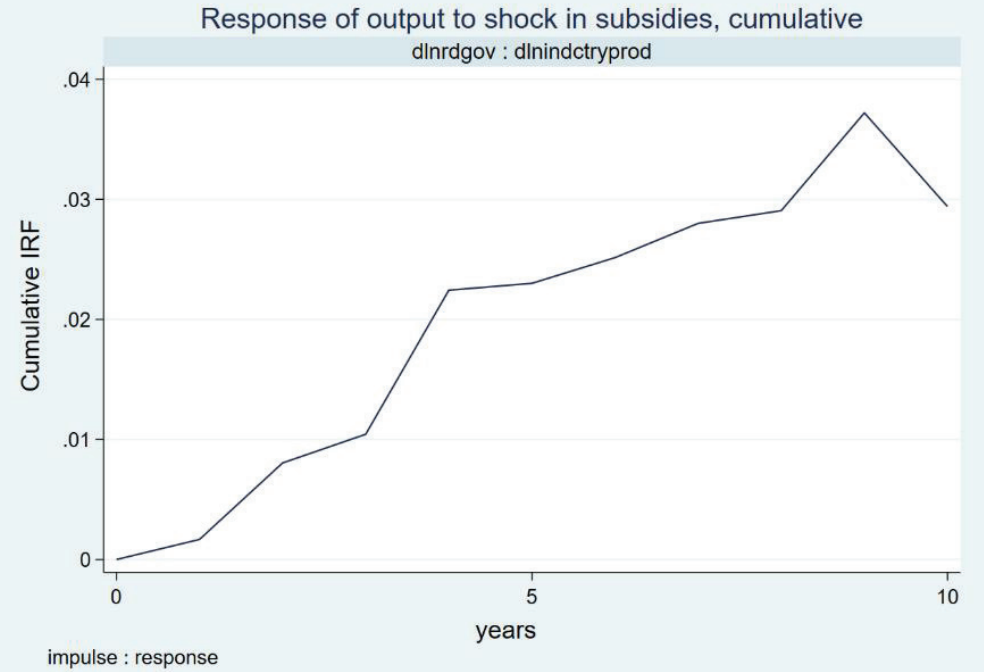

Notes: These graphs plot the impulse response functions based on OLS VAR models using the OECD panel data. The VAR model includes the following dependent variables: $\Delta \ln ($ public $R \& D)$ in a country-industry-year cell, $\Delta \ln$ (industry output) in a country-industry-year cell, as well as $\Delta \ln$ (country GDP); and allows for 10 lags (i.e. from t-1 to t-10) in each dependent variable. Panel A plots the impulse response function of $\Delta \ln$ (public R\&D) to a shock to $\Delta \ln$ (industry output), and Panel B plots the impulse response function of $\Delta \ln ($ industry output) to a shock to $\Delta \ln$ (public R\&D). The cumulative impacts are plotted from sum of the coefficients. Year are labelled so that $10=$ ten years after the shock, etc. 


\section{APPENDIX FIGURE A3: THE EFFECTS OF A 9/11 SHOCK OF US DEFENSE R\&D ON US AND FOREIGN TFP GROWTH AND PUBLIC AND PRIVATE R\&D}

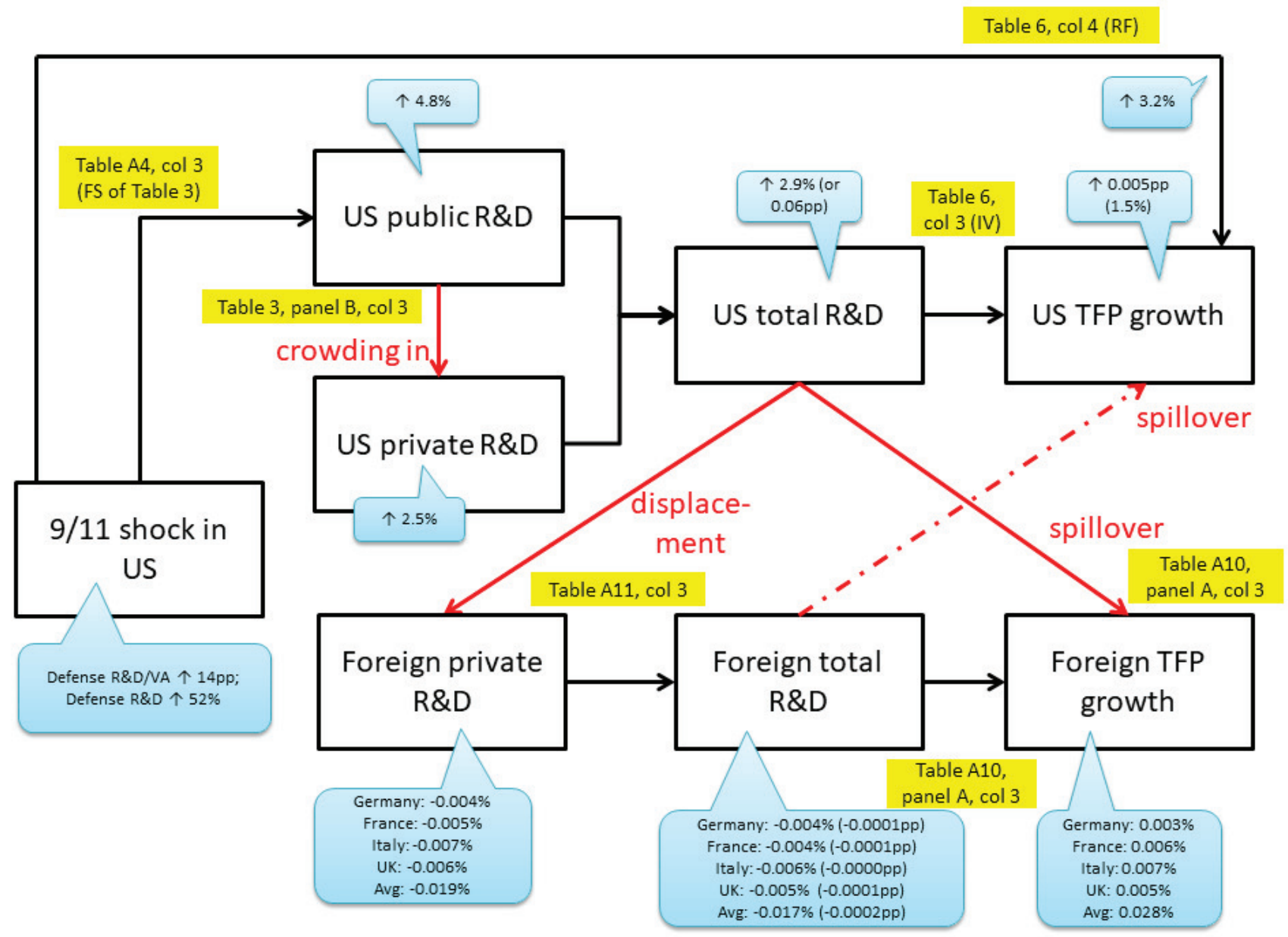

Note: This describes the links from an exogenous increase in US defense R\&D (calibrated to the increase after 9/11) to TFP growth in the US and overseas. Details are in Appendix B. 


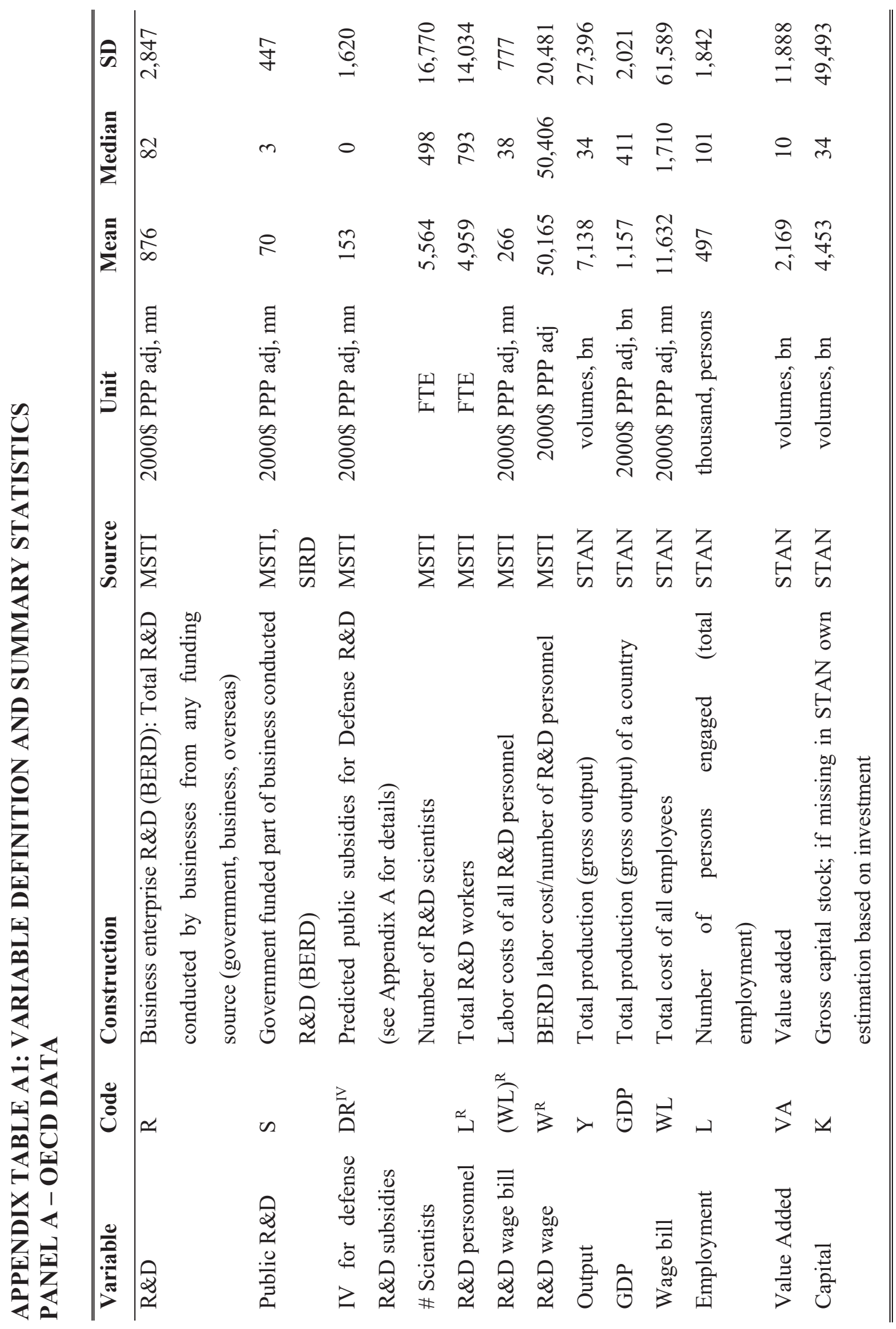




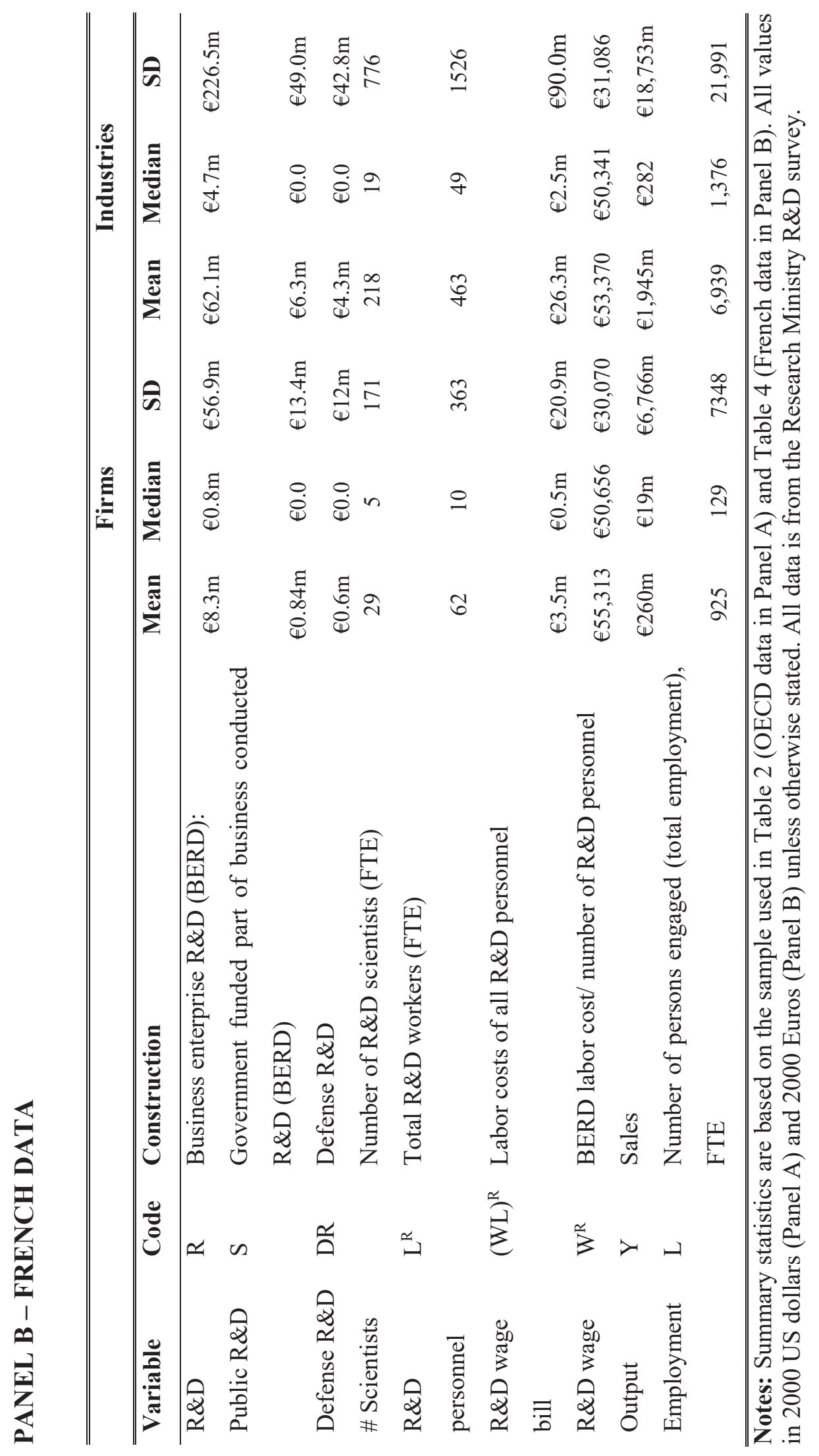




\section{APPENDIX TABLE A2: BUSINESS CONDUCTED R\&D (BERD) AS A PROPORTION OF GDP - BY COUNTRY}

\begin{tabular}{|c|c|c|c|c|c|c|c|c|}
\hline Country & Mean & $\begin{array}{l}\text { Standard } \\
\text { deviation }\end{array}$ & $\begin{array}{l}\text { Maximum- } \\
\text { Minimum }\end{array}$ & $\begin{array}{c}1987- \\
1991 \\
\text { Mean }\end{array}$ & $\begin{array}{c}1992- \\
1996 \\
\text { Mean }\end{array}$ & $\begin{array}{c}\text { 1997- } \\
2001 \\
\text { Mean }\end{array}$ & $\begin{array}{c}2002- \\
2006 \\
\text { Mean }\end{array}$ & $\begin{array}{c}2007- \\
2009 \\
\text { Mean }\end{array}$ \\
\hline Australia & 0.78 & 0.24 & 0.74 & 0.48 & 0.73 & 0.88 & 1.04 & \\
\hline Austria & 1.27 & 0.39 & 0.96 & 0.81 & 0.73 & 1.11 & 1.57 & 1.50 \\
\hline Belgium & 1.26 & 0.27 & 0.95 & 1.13 & 1.04 & 1.52 & 1.31 & \\
\hline Canada & 0.85 & 0.16 & 0.43 & 0.74 & 0.99 & & & 0.92 \\
\hline $\begin{array}{l}\text { Czech } \\
\text { Republic }\end{array}$ & 1.64 & 0.35 & 1.50 & & 1.84 & 1.81 & 1.54 & 1.27 \\
\hline Denmark & 0.89 & 0.36 & 1.06 & 0.63 & 0.72 & 1.19 & 1.65 & \\
\hline Estonia & 0.51 & 0.18 & 0.53 & & & 0.36 & 0.58 & 0.69 \\
\hline Finland & 1.58 & 0.64 & 1.87 & 0.77 & 1.15 & 2.10 & 2.14 & 2.00 \\
\hline France & 1.25 & 0.18 & 0.62 & 1.17 & 1.16 & 1.41 & 1.28 & 1.07 \\
\hline Germany & 1.52 & 0.29 & 0.95 & 1.50 & 1.19 & 1.66 & 1.70 & \\
\hline Greece & 0.19 & 0.06 & 0.20 & 0.12 & 0.14 & 0.23 & 0.23 & \\
\hline Hungary & 0.72 & 0.14 & 0.50 & 1.07 & 0.67 & 0.74 & 0.69 & 0.69 \\
\hline Italy & 0.63 & 0.07 & 0.23 & 0.67 & 0.57 & 0.63 & 0.68 & \\
\hline Japan & 1.53 & 0.34 & 1.14 & 1.42 & 1.17 & 1.61 & 2.03 & \\
\hline Netherlands & 1.02 & 0.16 & 0.50 & 1.09 & 0.85 & 1.16 & 0.98 & \\
\hline New & 0.38 & 0.13 & 0.41 & 0.30 & 0.33 & 0.46 & 0.55 & \\
\hline Zealand & & & & & & & & \\
\hline Norway & 0.69 & 0.10 & 0.36 & 0.66 & 0.68 & 0.81 & 0.69 & 0.58 \\
\hline Poland & 0.44 & 0.16 & 0.45 & & 0.58 & 0.56 & 0.30 & 0.25 \\
\hline Portugal & 0.23 & 0.11 & 0.43 & 0.17 & 0.14 & 0.25 & 0.37 & \\
\hline Slovakia & 1.01 & 0.67 & 2.49 & & 1.58 & 1.39 & 0.61 & 0.27 \\
\hline South & 2.71 & 0.47 & 1.71 & & 1.87 & 2.67 & 2.88 & 3.26 \\
\hline Korea & & & & & & & & \\
\hline Spain & 0.56 & 0.13 & 0.38 & 0.46 & 0.42 & 0.61 & 0.68 & 0.71 \\
\hline Sweden & 2.03 & 0.60 & 2.33 & 1.37 & 1.84 & 2.68 & 2.21 & 1.88 \\
\hline Switzerland & 1.44 & 0.21 & 0.51 & & 1.22 & 1.71 & 1.52 & 1.54 \\
\hline $\begin{array}{l}\text { United } \\
\text { Kingdom }\end{array}$ & 1.24 & 0.19 & 0.77 & 1.43 & 1.26 & 1.18 & 1.23 & 0.90 \\
\hline $\begin{array}{l}\text { United } \\
\text { States }\end{array}$ & 1.87 & 0.09 & 0.34 & 1.89 & 1.78 & 1.95 & 1.81 & 1.97 \\
\hline
\end{tabular}




\section{APPENDIX TABLE A3: BUSINESS CONDUCTED R\&D AS A PROPORTION OF VALUE ADDED - BY INDUSTRY}

\begin{tabular}{|c|c|c|c|c|c|c|c|}
\hline & $\begin{array}{c}\text { All } \\
\text { years }\end{array}$ & $\begin{array}{c}\text { All } \\
\text { years }\end{array}$ & $\begin{array}{c}1987- \\
1991 \\
\end{array}$ & $\begin{array}{c}1992- \\
1996 \\
\end{array}$ & $\begin{array}{l}1997- \\
2001 \\
\end{array}$ & $\begin{array}{c}2002- \\
2006 \\
\end{array}$ & $\begin{array}{l}2007 \\
2009\end{array}$ \\
\hline Industry & Mean & SD & Mean & Mean & Mean & Mean & Mean \\
\hline Agriculture, hunting and forestry & 0.30 & 0.36 & 0.23 & 0.26 & 0.34 & 0.35 & 0.29 \\
\hline Basic metals & 3.81 & 14.25 & 2.19 & 1.98 & 7.36 & 3.17 & 1.35 \\
\hline Construction & 0.18 & 0.27 & 0.10 & 0.14 & 0.22 & 0.25 & 0.21 \\
\hline Chemicals and chemical products & 10.84 & 6.63 & 8.92 & 9.38 & 11.65 & 12.29 & 13.67 \\
\hline $\begin{array}{l}\text { Coke, refined petroleum products and } \\
\text { nuclear fuel }\end{array}$ & 5.60 & 18.74 & 3.73 & 4.23 & 4.35 & 4.73 & 29.73 \\
\hline $\begin{array}{l}\text { Community, social \& personal services, } \\
\text { etc. }\end{array}$ & 0.04 & 0.08 & 0.04 & 0.03 & 0.05 & 0.04 & 0.06 \\
\hline Electricity, gas and water supply & 0.54 & 0.89 & 0.61 & 0.48 & 0.52 & 0.39 & 1.22 \\
\hline Electrical machinery and apparatus n.e.c & 8.68 & 17.02 & 5.98 & 6.92 & 12.26 & 8.70 & 5.22 \\
\hline $\begin{array}{l}\text { Finance, insurance, real estate and } \\
\text { business activities }\end{array}$ & 1.17 & 2.69 & 0.42 & 0.87 & 1.10 & 1.38 & 3.21 \\
\hline $\begin{array}{l}\text { Fabricated metal products, except } \\
\text { machinery and equipment }\end{array}$ & 0.99 & 0.79 & 0.89 & 0.94 & 1.01 & 1.01 & 1.40 \\
\hline Food, beverages and tobacco & 1.23 & 1.63 & 0.92 & 0.90 & 1.27 & 1.41 & 2.88 \\
\hline Mining and quarrying & 0.98 & 1.25 & 0.88 & 1.01 & 1.09 & 0.96 & 0.59 \\
\hline Machinery and equipment, n.e.c. & 4.91 & 4.08 & 3.66 & 4.31 & 5.21 & 5.56 & 7.42 \\
\hline Manufacturing n.e.c. and recycling & 1.17 & 1.28 & 1.15 & 0.90 & 1.22 & 1.31 & 1.54 \\
\hline $\begin{array}{l}\text { Medical, precision and optical } \\
\text { instruments, watches and clocks } \\
\text { (instruments) }\end{array}$ & 11.85 & 11.98 & 8.32 & 10.64 & 12.37 & 13.15 & 17.98 \\
\hline Motor Vehicles, trailers and semi-trailers & 10.16 & 10.01 & 11.15 & 8.99 & 9.85 & 10.15 & 14.55 \\
\hline Non-metallic mineral products & 1.31 & 0.94 & 1.24 & 1.14 & 1.43 & 1.44 & 1.19 \\
\hline $\begin{array}{l}\text { Office, accounting and computing } \\
\text { machinery }\end{array}$ & 25.12 & 56.00 & 32.57 & 19.76 & 15.91 & 36.31 & 24.35 \\
\hline Other Transport Equipment & 11.36 & 11.27 & 11.01 & 11.50 & 12.80 & 10.47 & 8.78 \\
\hline $\begin{array}{l}\text { Pulp, paper, paper products, printing and } \\
\text { publishing }\end{array}$ & 0.59 & 0.51 & 0.48 & 0.58 & 0.61 & 0.63 & 0.60 \\
\hline $\begin{array}{l}\text { Radio, TV, communications equipment \& } \\
\text { apparatus }\end{array}$ & 23.67 & 15.96 & 24.49 & 21.85 & 24.80 & 24.34 & 20.20 \\
\hline Rubber and plastic products & 2.65 & 2.26 & 1.69 & 2.69 & 3.00 & 2.74 & 3.52 \\
\hline Textiles, fur and leather & 1.00 & 0.86 & 0.58 & 0.74 & 1.06 & 1.32 & 1.93 \\
\hline Transport, storage and communications & 0.47 & 0.95 & 0.24 & 0.31 & 0.57 & 0.44 & 1.33 \\
\hline $\begin{array}{l}\text { Wholesale and retail trade; restaurants } \\
\text { and hotels }\end{array}$ & 0.24 & 0.34 & 0.11 & 0.16 & 0.26 & 0.29 & 0.42 \\
\hline Wood and cork (not furniture) & 0.47 & 0.71 & 0.45 & 0.36 & 0.49 & 0.47 & 0.93 \\
\hline
\end{tabular}




\section{APPENDIX TABLE A4: FIRST STAGE OF TABLE 3, PANEL B}
(1)
(2)
(3)
(4)
(5)
(6)

Dependent variable: $\ln$ (Privately funded business R\&D)

\begin{tabular}{|c|c|c|c|c|c|c|}
\hline $\ln (\text { predicted defense } R \& D)_{t-1}$ & $\begin{array}{c}0.092 * * \\
(0.023)\end{array}$ & $\begin{array}{c}0.092 * * \\
(0.028)\end{array}$ & $\begin{array}{c}0.092 * * \\
(0.028)\end{array}$ & $\begin{array}{c}0.096 * * \\
(0.028)\end{array}$ & $\begin{array}{c}0.096 * * \\
(0.030)\end{array}$ & $\begin{array}{c}0.101 * * \\
(0.030)\end{array}$ \\
\hline $\mathrm{R} \& \mathrm{D}$ tax credit $_{\mathrm{t}-1}$ & & & & $\begin{array}{l}-0.820 \\
0695)\end{array}$ & $\begin{array}{r}-0.814 \\
(0693)\end{array}$ & $\begin{array}{l}-1.012 \\
(0677)\end{array}$ \\
\hline $\ln (\text { Non-bus. public R\&D) })_{t-1}$ & & & & & $\begin{array}{c}-0.025 \\
(0.276)\end{array}$ & $\begin{array}{c}-0.074 \\
(0.266)\end{array}$ \\
\hline$(\text { Corp. tax revenue/GDP })_{t-1}$ & & & & & & $\begin{array}{l}9.871 * \\
(5.425)\end{array}$ \\
\hline $\ln (\text { output })_{t-1}$ & & & $\begin{array}{l}0.716^{*} \\
(0.385)\end{array}$ & $\begin{array}{c}0.703^{*} \\
(0.385)\end{array}$ & $\begin{array}{l}0.698 * \\
(0.397)\end{array}$ & $\begin{array}{l}0.738^{*} \\
(0.392)\end{array}$ \\
\hline $\ln (G D P)_{t-1}$ & & & $\begin{array}{l}-0.657 \\
(0.524)\end{array}$ & $\begin{array}{l}-0.633 \\
(0.524)\end{array}$ & $\begin{array}{l}-0.625 \\
(0.559)\end{array}$ & $\begin{array}{c}-0.683 \\
(0.555)\end{array}$ \\
\hline Observations & 5,026 & 4,389 & 4,389 & 4,389 & 4,389 & 4,389 \\
\hline
\end{tabular}

Notes: Two-way clustered standard errors at the industry*country and country*year level. All columns include a full set of country by industry fixed effects and a full set of industry by year fixed effects, as well as linear country trends. All regressions are weighted by the industry-country pair's initial share of employment in total country employment. ** significant at $5 \%$ level, * significant at $10 \%$ level. 


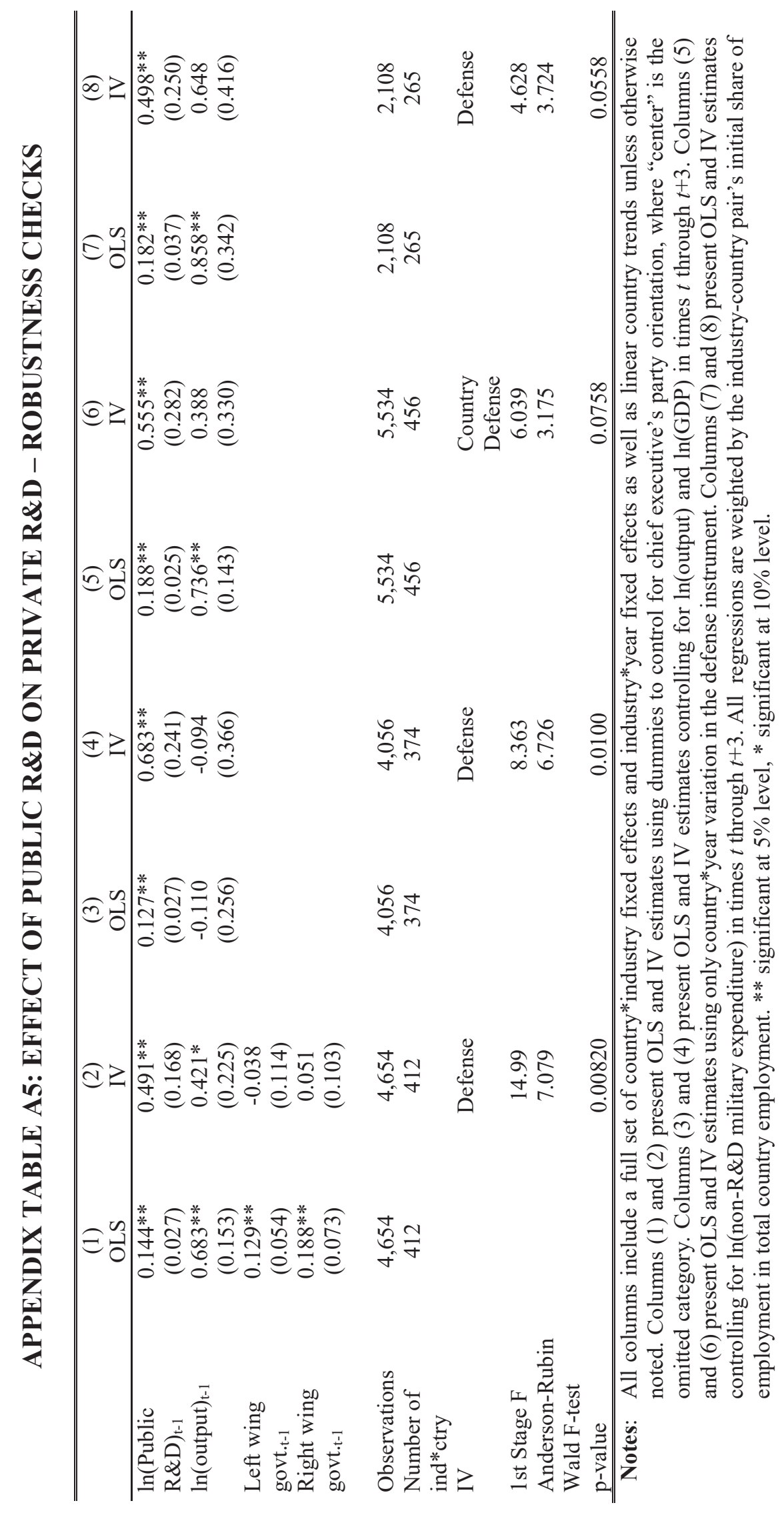




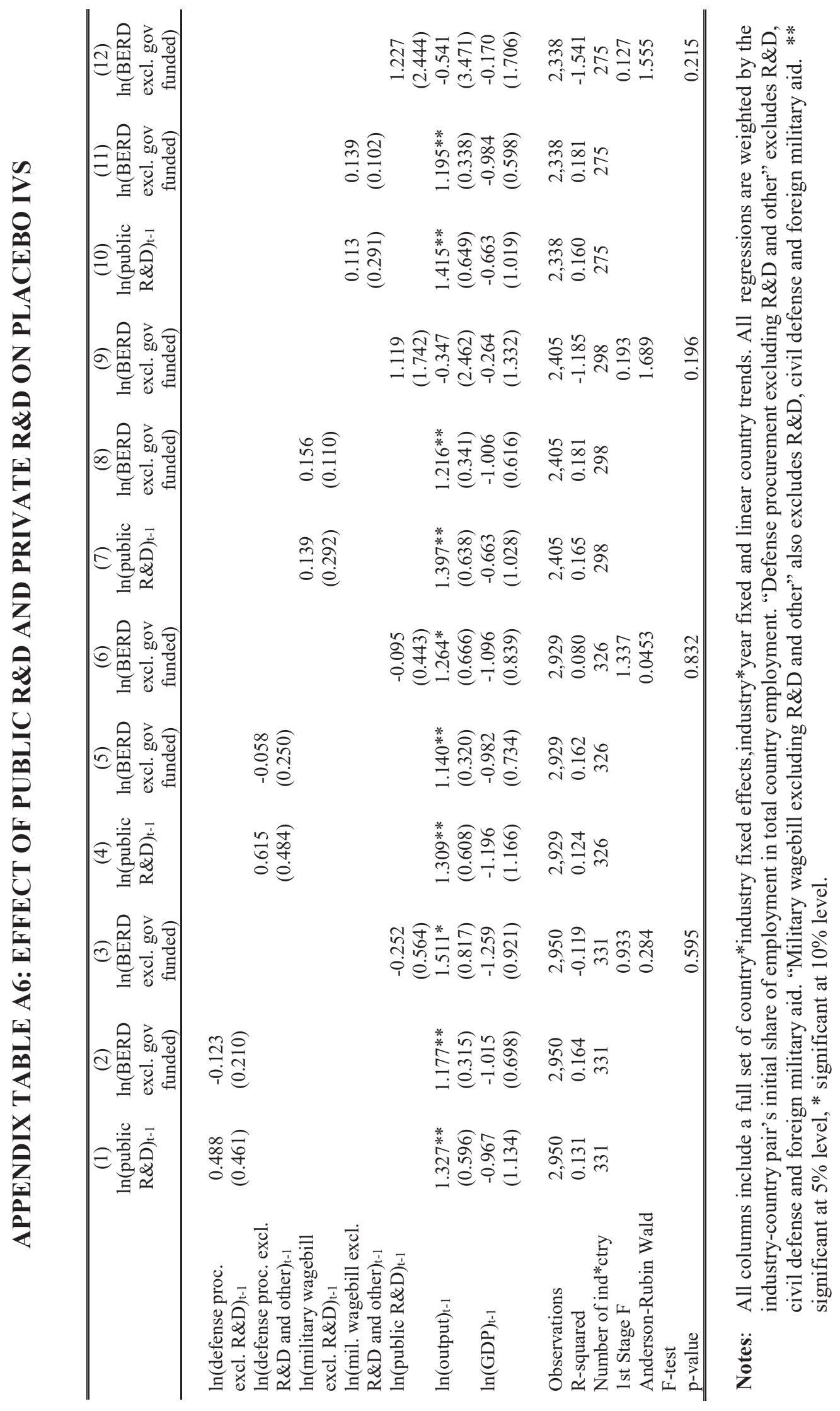




\section{APPENDIX TABLE A7: FIRST STAGE OF TABLE 4 - FRENCH DATA}

\begin{tabular}{|c|c|c|}
\hline & $\begin{array}{c}(1) \\
\ln (\text { public } \\
\text { R\&D }+1)_{t-1}\end{array}$ & $\begin{array}{c}(2) \\
\ln (\text { defense } \\
\text { R\&D }+1) t-1\end{array}$ \\
\hline $\begin{array}{l}\text { Panel A. 3-digit industry } \\
\ln (\text { predicted defense } \\
\text { R\&D) })_{t-1}\end{array}$ & $\begin{array}{c}0.120 * * * \\
(0.035)\end{array}$ & $\begin{array}{c}0.278 * * * \\
(0.057)\end{array}$ \\
\hline Observations & 4,444 & 4,444 \\
\hline $\begin{array}{l}\text { Panel B. Firm-level } \\
\ln (\text { predicted defense } \\
\text { R\&D)t-1 }\end{array}$ & $\begin{array}{c}0.018 * * * \\
(0.005)\end{array}$ & $\begin{array}{c}0.006^{* * *} * \\
(0.002)\end{array}$ \\
\hline Observations & 80,692 & 81,201 \\
\hline
\end{tabular}

Notes: Standard errors in Panel A are clustered at the 2-digit industry level; in Panel B are clustered at the 3-digit industry level. All columns include year fixed effects; Panel A includes 3-digit industry fixed effects. Panel B includes firm fixed effects. Variables in panel B are winsorized at the $0.5 \%$ tails. The instrument is defense R\&D subsidies. ${ }^{* *}$ significant at $5 \%$ level, * significant at $10 \%$ level. 


\section{APPENDIX TABLE A8: EFFECT ON EMPLOYMENT AND WAGES}

\begin{tabular}{|c|c|c|c|c|c|}
\hline & $\begin{array}{c}(1) \\
\ln (\text { BERD excl. } \\
\text { gov funded) }\end{array}$ & $\begin{array}{c}(2) \\
\ln (\text { BERD excl. } \\
\text { gov funded })\end{array}$ & $\begin{array}{c}(3) \\
\ln (\mathrm{R} \& \mathrm{D} \\
\text { personnel })\end{array}$ & $\begin{array}{c}(4) \\
\ln (\text { employment } \\
\text { excluding R\&D) }\end{array}$ & $\begin{array}{c}(5) \\
\ln (\mathrm{R} \& \mathrm{D} \text { labor } \\
\text { cost/R\&D } \\
\text { personnel })\end{array}$ \\
\hline \multicolumn{6}{|c|}{ PANEL A: OLS } \\
\hline \multicolumn{6}{|c|}{ OECD country-industries } \\
\hline $\ln (\text { public } R \& D)_{t-1}$ & $\begin{array}{c}0.128 * * \\
(0.028)\end{array}$ & $\begin{array}{c}0.088^{* *} \\
(0.032)\end{array}$ & $\begin{array}{c}0.099 * * \\
(0.042)\end{array}$ & $\begin{array}{c}0.007 * * \\
(0.003)\end{array}$ & $\begin{array}{l}0.066^{*} \\
(0.040)\end{array}$ \\
\hline Observations & 5,026 & 3,817 & 3,817 & 3,817 & 3,817 \\
\hline \multicolumn{6}{|c|}{ French 3-digit industries } \\
\hline $\ln (\text { public } R \& D)_{t-1}$ & $\begin{array}{c}0.069 * * * \\
(0.011)\end{array}$ & $\begin{array}{c}0.403 * * * \\
(0.090)\end{array}$ & $\begin{array}{c}0.394 * * * \\
(0.069)\end{array}$ & $\begin{array}{c}0.324 * * * \\
(0.086)\end{array}$ & $\begin{array}{c}0.006 * * * \\
(0.002)\end{array}$ \\
\hline Observations & 4,444 & 3,982 & 3,982 & 3,982 & 3,982 \\
\hline $\begin{array}{l}\text { French firms } \\
\ln (\text { public } R \& D)_{t-1}\end{array}$ & $\begin{array}{l}0.011 * * * \\
(0.002)\end{array}$ & $\begin{array}{c}0.011 * * * \\
(0.002)\end{array}$ & $\begin{array}{c}0.013 * * * \\
(0.001)\end{array}$ & $\begin{array}{c}0.001 \\
(0.001)\end{array}$ & $\begin{array}{c}0.004 * * * \\
(0.001)\end{array}$ \\
\hline Observations & 80,692 & 80,044 & 80,044 & 80,044 & 80,044 \\
\hline \multicolumn{6}{|c|}{ PANEL B: IV } \\
\hline \multicolumn{6}{|c|}{ OECD country-industries } \\
\hline $\ln (\text { public } R \& D)_{t 1}$ & $\begin{array}{c}0.561^{* *} \\
(0.140)\end{array}$ & $\begin{array}{l}0.400 * * \\
(0.105)\end{array}$ & $\begin{array}{c}0.142 \\
(0.183)\end{array}$ & $\begin{array}{c}0.087 * * \\
(0.030)\end{array}$ & $\begin{array}{c}0.167 \\
(0.138)\end{array}$ \\
\hline Observations & 5,026 & 3,817 & 3,817 & 3,817 & 3,817 \\
\hline First stage F & 14.66 & 9.099 & 9.099 & 9.099 & 9.099 \\
\hline \multicolumn{6}{|c|}{ French 3-digit industries } \\
\hline $\ln (\text { public } \mathrm{R} \& \mathrm{D})_{\mathrm{t} 1}$ & $\begin{array}{c}0.346^{* * *} \\
(0.092)\end{array}$ & $\begin{array}{c}0.403 * * * \\
(0.090)\end{array}$ & $\begin{array}{c}0.394 * * * \\
(0.069)\end{array}$ & $\begin{array}{c}0.324 * * * \\
(0.086)\end{array}$ & $\begin{array}{c}0.009 \\
(0.013)\end{array}$ \\
\hline Observations & 4,444 & 3,982 & 3,982 & 3,982 & 3,982 \\
\hline First stage F & 11.56 & 10.40 & 10.40 & 10.40 & 10.40 \\
\hline $\begin{array}{l}\text { French firms } \\
\ln (\text { public } R \& D)_{t 1}\end{array}$ & $\begin{array}{l}0.119 * \\
(0.069)\end{array}$ & $\begin{array}{c}0.114 \\
(0.071)\end{array}$ & $\begin{array}{l}0.114 * * \\
(0.049)\end{array}$ & $\begin{array}{c}0.019 \\
(0.057)\end{array}$ & $\begin{array}{c}0.033 \\
(0.043)\end{array}$ \\
\hline Observations & 80,692 & 80,044 & 80,044 & 80,044 & 80,044 \\
\hline First stage F & 13.76 & 13.51 & 13.51 & 13.51 & 13.51 \\
\hline
\end{tabular}

Notes: The dependent variable is private $R \& D$, i.e., $R \& D$ conducted in the business sector (BERD) that is also financed by the private sector (i.e., excludes government financed R\&D). "Public R\&D" is government-financed R\&D performed by private firms. Regresions using OECD data are weighted by the industry-country pair's initial share of employment in total country employment. ** significant at $5 \%$ level, * significant at $10 \%$ level. 


\section{APPENDIX TABLE A9: DOMESTIC AND INTERNATIONAL SPILLOVERS - OLS ESTIMATES}

\begin{tabular}{|c|c|c|c|c|c|c|}
\hline $\begin{array}{l}\text { Measure of neighbor } \\
\text { for spillover } \\
\text { Dependent variable: } \ln (\mathrm{P}\end{array}$ & $\begin{array}{l}\text { (1) } \\
\text { Baseline } \\
\text { ately funde }\end{array}$ & $\begin{array}{c}\text { (2) } \\
\text { Per-capita } \\
\text { GDP } \\
\text { iness R\&D) }\end{array}$ & $\begin{array}{c}\text { (3) } \\
\text { Geo- } \\
\text { graphy }\end{array}$ & $\begin{array}{c}(4) \\
\text { Skill } \\
\text { Intensity }\end{array}$ & $\begin{array}{c}(5) \\
\text { Tech- } \\
\text { nology }\end{array}$ & $\begin{array}{c}(6) \\
\text { R\&D } \\
\text { Intensity }\end{array}$ \\
\hline Panel A. Effect of Publ & \&D & & & & & \\
\hline $\ln (\text { public } R \& D)_{t-1}$ & $\begin{array}{c}0.128 * * \\
(0.028)\end{array}$ & $\begin{array}{l}0.133 * * \\
(0.029)\end{array}$ & $\begin{array}{l}0.140 * * \\
(0.025)\end{array}$ & $\begin{array}{l}0.129 * * \\
(0.030)\end{array}$ & $\begin{array}{l}0.155 * * \\
(0.029)\end{array}$ & $\begin{array}{l}0.130 * * \\
(0.029)\end{array}$ \\
\hline $\begin{array}{l}\ln \text { (int. public } \\
\text { R\&D)t-1 }\end{array}$ & & $\begin{array}{l}0.058 * \\
(0.031)\end{array}$ & $\begin{array}{c}0.150 \\
(0.091)\end{array}$ & $\begin{array}{l}-0.007 \\
(0.051)\end{array}$ & $\begin{array}{l}0.286 * * \\
(0.120)\end{array}$ & $\begin{array}{c}0.022 \\
(0.052)\end{array}$ \\
\hline Observations & 5,026 & 5,022 & 5,022 & 4,582 & 5,022 & 5,022 \\
\hline \multicolumn{7}{|c|}{ Panel B. Effect of Business R\&D } \\
\hline $\ln (\text { public } R \& D)_{t-1}$ & $\begin{array}{c}0.128 * * \\
(0.028)\end{array}$ & $\begin{array}{c}0.128 * * \\
(0.028)\end{array}$ & $\begin{array}{l}0.119 * * \\
(0.029)\end{array}$ & $\begin{array}{c}0.130 * * \\
(0.029)\end{array}$ & $\begin{array}{l}0.116 * * \\
(0.029)\end{array}$ & $\begin{array}{c}0.126 * * \\
(0.028)\end{array}$ \\
\hline $\begin{array}{l}\ln (\text { int. business } \\
\text { R\&D) })_{t-1}\end{array}$ & & $\begin{array}{l}-0.014 \\
(0.039)\end{array}$ & $\begin{array}{c}-0.327^{* *} \\
(0.090)\end{array}$ & $\begin{array}{l}-0.046 \\
(0.068)\end{array}$ & $\begin{array}{c}-0.779 * * \\
(0.155)\end{array}$ & $\begin{array}{c}-0.286 * * \\
(0.096)\end{array}$ \\
\hline Observations & 5,026 & 5,022 & 5,022 & 4,582 & 5,022 & 5,022 \\
\hline \multicolumn{7}{|c|}{ Panel C. Effects of Public and Business R\&D } \\
\hline $\ln (\text { public } R \& D)_{t-1}$ & $\begin{array}{c}0.128 * * \\
(0.028)\end{array}$ & $\begin{array}{c}0.137 * * \\
(0.028)\end{array}$ & $\begin{array}{l}0.138 * * \\
(0.026)\end{array}$ & $\begin{array}{l}0.131 * * \\
(0.029)\end{array}$ & $\begin{array}{l}0.158 * * \\
(0.028)\end{array}$ & $\begin{array}{l}0.139 * * \\
(0.029)\end{array}$ \\
\hline $\ln (\text { int. public } \mathrm{R} \& \mathrm{D})_{\mathrm{t}-1}$ & & $\begin{array}{l}0.128 * * \\
(0.051)\end{array}$ & $\begin{array}{l}0.294 * * \\
(0.124)\end{array}$ & $\begin{array}{c}0.011 \\
(0.067)\end{array}$ & $\begin{array}{c}0.464 * * \\
(0.158)\end{array}$ & $\begin{array}{c}0.144 * * \\
(0.045)\end{array}$ \\
\hline $\ln (\text { int. business } R \& D)_{t-1}$ & & $\begin{array}{l}-0.103^{*} \\
(0.062)\end{array}$ & $\begin{array}{c}-0.455^{* *} \\
(0.127)\end{array}$ & $\begin{array}{l}-0.053 \\
(0.090)\end{array}$ & $\begin{array}{c}-0.926^{* * *} \\
(0.179)\end{array}$ & $\begin{array}{c}-0.379 * * \\
(0.102)\end{array}$ \\
\hline Observations & 5,026 & 5,022 & 5,022 & 4,582 & 5,022 & 5,022 \\
\hline
\end{tabular}

Notes: ** significant at 5\% level, * significant at 10\% level. Each colum in each panel presents a separate regression. Twoway clustered standard errors at the industry-country and country-year level. All columns use a full set of country*industry fixed effects and industry*year fixed effects as well as linear country trends. All regressions are weighted by the industrycountry pair's initial share of employment in total country employment. The dependent variable is private R\&D, i.e., R\&D conducted in the business sector (BERD) that is also financed by the private sector (i.e., excludes government financed R\&D). "Public R\&D" is government-financed R\&D performed by private firms. "Int. public R\&D" is the weighted average of other countries' public R\&D in the same industry and year, where each column uses different weights. "Int. total R\&D" is the weighted average of other countries' public and private R\&D in the same industry and year, where each column uses different weights. Weights $\omega_{k l}$ are a "distance" measure between country $k$ and country $l$ measured by: (2) GDP per capita. $\omega_{k l}=$ $1 / \mid G D P$ cap $_{k}-G D P c a p l \mid$; (3) Geographic distance. $\omega_{k l}=1 /$ dist $_{k l}$ where geographic distance is measured in kilometers between capital cities; (4) Skill intensity. $\omega_{k l}=1 / \mid$ tert $_{k}-$ tert $_{l} \mid$ with tert $_{l}$ being the share of population with tertiary education in country $l$; (5) Patent similarity. $\omega_{k l}=\sqrt{\sum_{i}\left(p a t_{i k}-p a t_{i l}\right)^{2}}$, pat $t_{i k}$ and $p a t_{i l}$ are patent share of a specific technology class $I$ (out of 15 patent technology classes) in country $k$ or $l$ (of total patents in that country); (6) R\&D intensity. $\omega_{k l}=$ $1 /\left|\frac{\text { Total } R \& D_{k}}{G D P_{k}}-\frac{\text { Total } R \& D_{l}}{G D P_{l}}\right|$. 


\section{APPENDIX TABLE A10: INTERNATIONAL SPILLOVER EFFECTS OF R\&D SUBSIDIES ON TFP GROWTH}

\begin{tabular}{|c|c|c|c|c|c|c|}
\hline $\begin{array}{l}\text { Measure of neighbor } \\
\text { for spillover } \\
\text { Dependent variable: }\end{array}$ & $\begin{array}{c}(1) \\
\text { Baseline }\end{array}$ & $\begin{array}{l}\text { (2) } \\
\text { Per-capita } \\
\text { GDP }\end{array}$ & $\begin{array}{c}\text { (3) } \\
\text { Geo- } \\
\text { graphy }\end{array}$ & $\begin{array}{c}\text { (4) } \\
\text { Skill } \\
\text { Intensity }\end{array}$ & $\begin{array}{c}(5) \\
\text { Tech- } \\
\text { nology }\end{array}$ & $\begin{array}{c}\text { (6) } \\
\text { R\&D } \\
\text { Intensity }\end{array}$ \\
\hline $\begin{array}{l}\text { Panel A. OLS } \\
\text { (R\&D/value } \\
\text { added)t-1 } \\
\text { (International R\&D/ } \\
\text { value added) } \mathrm{t}-1\end{array}$ & $\begin{array}{c}0.095 * * \\
(0.040)\end{array}$ & $\begin{array}{c}0.053 \\
(0.032) \\
0.170 * * \\
(0.051)\end{array}$ & $\begin{array}{c}0.029 \\
(0.023) \\
0.214 * * \\
(0.039)\end{array}$ & $\begin{array}{c}0.046 \\
(0.033) \\
0.207 * * \\
(0.043)\end{array}$ & $\begin{array}{c}0.017 \\
(0.020) \\
0.253 * * \\
(0.049)\end{array}$ & $\begin{array}{c}0.042 \\
(0.030) \\
0.168 * * \\
(0.054)\end{array}$ \\
\hline Observations & 6,102 & 6,096 & 6,096 & 5,280 & 6,096 & 6,096 \\
\hline $\begin{array}{l}\text { Panel B. IV } \\
(\text { R\&D/value } \\
\text { added)t-1 } \\
\text { (International R\&D/ } \\
\text { value added) } \mathrm{t}-1\end{array}$ & $\begin{array}{c}0.094 * * \\
(0.033)\end{array}$ & $\begin{array}{c}0.026 \\
(0.033) \\
0.201 * * \\
(0.078)\end{array}$ & $\begin{array}{c}0.004 \\
(0.023) \\
0.237 * * \\
(0.055)\end{array}$ & $\begin{array}{c}0.033 \\
(0.083) \\
0.219^{* *} \\
(0.088)\end{array}$ & $\begin{array}{l}-0.032 \\
(0.023) \\
0.304 * * \\
(0.070)\end{array}$ & $\begin{array}{c}0.021 \\
(0.028) \\
0.188^{* *} \\
(0.068)\end{array}$ \\
\hline $\begin{array}{l}\text { Observations } \\
\text { First stage F }\end{array}$ & $\begin{array}{l}6,102 \\
14.93\end{array}$ & $\begin{array}{l}6,096 \\
6.434\end{array}$ & $\begin{array}{l}6,096 \\
8.772\end{array}$ & $\begin{array}{l}5,280 \\
8.659\end{array}$ & $\begin{array}{l}6,096 \\
6.768\end{array}$ & $\begin{array}{l}6,096 \\
8.333\end{array}$ \\
\hline
\end{tabular}

Notes: ** significant at 5\% level, * significant at $10 \%$ level. Standard errors are two-way clustered at the industry*country and country*year level except for column (4) in Panel B, where they are clustered only at the industry*country level due to computational problems for the former. All regressions include a full set of country and year fixed effects, as well as linear country trends. All regressions are weighted by the industry-country pair's initial share of employment in total country employment. The dependent variable is TFP growth over 1 year. "International R\&D/value added" is the weighted average of other countries' total R\&D/value added in the same industry and year, where each column uses different weights. "R\&D" is the total R\&D conducted in the business sector (both financed by the private sector and by government). Weights $\omega_{k l}$ are a "distance" measure between country $k$ and country $l$ and measured by: (2) GDP per capita. $\omega_{k l}=1 / a b s\left(G D P c a p_{k}-\right.$ GDPcap $)$ ); (3) Geographic distance. $\omega_{k l}=1 /$ dist $_{k l}$ where geographical distance is measured in kms between capital cities; (4) Skill intensity. $\omega_{k l}=1 / a b s\left(\operatorname{tert}_{k}-\right.$ tert $\left._{l}\right)$ with tert $t_{l}$ being the share of population with tertiary education in country l; (5) Patent similarity. $\omega_{k l}=\sqrt{\sum_{i}\left(p_{i k}-p_{i l}\right)^{2}}$, pat $_{i k}$ and $p a t_{i l}$ are patent share of a specific technology class $i$ (out of 15 patent technology classes) in country $k$ or $l$ (of total patents in that country); (6) R\&D intensity. $\omega_{k l}=$ $1 / a b s\left(\frac{\text { Total } R \& D_{k}}{G D P_{k}}-\frac{\text { Total } R \& D_{l}}{G D P_{l}}\right)$ 


\section{APPENDIX TABLE A11: INTERNATIONAL DISPLACEMENT EFFECTS OF PUBLIC R\&D - FOR ILLUSTRATION OF MAGNITUDE OF EFFECTS}

\begin{tabular}{lcccccc}
\hline \hline & $\begin{array}{c}(1) \\
\text { Measure of neighbor }\end{array}$ & $\begin{array}{c}(2) \\
\text { Per-capita } \\
\text { for spillover: }\end{array}$ & $\begin{array}{c}(3) \\
\text { Geo- } \\
\text { graphy }\end{array}$ & $\begin{array}{c}(4) \\
\text { Skill } \\
\text { Intensity }\end{array}$ & $\begin{array}{c}(5) \\
\text { Tech- } \\
\text { nology }\end{array}$ & $\begin{array}{c}(6) \\
\text { R\&D } \\
\text { Intensity }\end{array}$ \\
\hline $\begin{array}{l}\text { Dependent variable: In(Privately funded business R\&D) } \\
\text { ln(Domestic Public R\&D) }\end{array}$ & $0.235^{* *}$ & $0.243^{* *}$ & $0.242^{* *}$ & $0.247^{* *}$ & $0.239^{* *}$ & $0.244^{* *}$ \\
& $(0.038)$ & $(0.038)$ & $(0.038)$ & $(0.040)$ & $(0.037)$ & $(0.037)$ \\
$\ln ($ Int. Total R\&D) & & 0.001 & $-0.325^{* *}$ & -0.086 & $-0.850^{* *}$ & $\begin{array}{c}-0.278^{* *} \\
(0.086)\end{array}$ \\
& & $(0.064)$ & $(0.102)$ & $(0.086)$ & $(0.277)$ & 6,479 \\
\hline
\end{tabular}

Notes: $* *$ significant at $5 \%$ level, * significant at $10 \%$ level. Each column in each panel constitutes a separate regression. Two-way clustered standard errors at the industry*country and country*year level. All columns include a full set of country*industry fixed effects and industry*year fixed effects, as well as linear country trends. All regressions are weighted by the industry-country pair's initial share of employment in total country employment. The dependent variable is private $R \& D$, i.e. R\&D conducted in the business sector (BERD) that is also financed by the private sector (i.e. excludes government financed -R\&D). "Public R\&D" is government financed R\&D performed by private firms. "Int. Total R\&D" is the weighted average of other countries' public and private $R \& D$ in the same industry and year, where each column uses different weights. Weights $\omega_{k l}$ are a "distance" measure between country $k$ and country $l$ and measured by: (2) GDP per capita. $\omega_{k l}=$ $1 / a b s\left(\right.$ GDPcap $_{k}-$ GDPcap $\left._{l}\right)$; (3) Geographic distance. $\omega_{k l}=1 /$ dist $_{k l}$ where geographical distance is measured in kms between capital cities; (4) Skill intensity. $\omega_{k l}=1 / a b s\left(\right.$ tert $_{k}-$ tert $\left._{l}\right)$ with tert $_{l}$ being the share of population with tertiary education in country l; (5) Patent similarity. $\omega_{k l}=\sqrt{\sum_{i}\left(p_{i k}-p_{i l}\right)^{2}}, p_{i k}$ and $p a t_{i l}$ are patent share of a specific technology class $i$ (out of 15 patent technology classes) in country $k$ or $l$ (of total patents in that country); (6) R\&D intensity. $\omega_{k l}=1 / a b s\left(\frac{\text { Total } R \& D_{k}}{G D P_{k}}-\frac{\text { Total } R \& D_{l}}{G D P_{l}}\right)$; 